\title{
Overheidscontracten in het Belgische recht: besturen op de snijlijn van privaat- en publiekrecht ${ }^{I}$
}

Steven Lierman, Pieter-Jan Van de Weyer en Karel-Jan Vandormael ${ }^{*}$

\section{Proloog}

I. Het overheidsoptreden wordt traditioneel geassocieerd met de uitoefening van eenzijdige rechtshandelingen met individueel of reglementair karakter. Deze omschrijving van het overheidsgebeuren doet de realiteit geen recht. Naast deze gezagsuitoefening makt de overheid immers steeds vaker gebruik van het privaatrechtelijke procedé om het algemeen belang te behartigen. Dit preadvies gaat voorbij aan de (uiteenlopende) redenen van deze evolutie en concentreert zich op de juridische probleemstelling. Deze praktijk stelt de wetgever en de rechter immers voor een uitdagende opdracht. Binnen welke grenzen mag het bestuur de privaatrechtelijke weg bewandelen en welke regels beheersen deze privaatrechtelijke verhoudingen: is het privaatrecht erop van toepassing of geldt een publiekrechtelijke regeling? Dit preadvies meandert over de oude breuklijn tussen publiek en privaatrecht en bespreekt op welke wijze regels en beginselen van beide zijden het algemeen belang dienen.

2. Wanneer is het de overheid toegestaan om gebruik te maken van privaatrechtelijke procedés ter realisatie van haar doelstelling om het algemeen belang te dienen of een openbare dienst in te richten? Deze vraag staat centraal in het eerste luik van dit preadvies (hoofdstuk 2). Uiteraard gaat onze aandacht in dit hoofdstuk naar de in België gehuldigde tweewegenleer en de principiële vrije keuze van de overheid om het algemeen belang te behartigen door middel van privaatrecht i.p.v. zich te beroepen op haar bijzondere prerogatieven. In geen geval biedt de tweewegenleer de overheid echter een vrijbrief om de privaatrechtelijke weg te bewandelen. Dit kan slechts binnen in essentie publiekrechtelijke contouren. We slaan hierbij in het bijzonder acht op het specialiteits- en het legaliteitsbeginsel, de beginselen van behoorlijk bestuur en de wetten van de openbare dienst.

I Dit artikel werd geschreven op basis van een analyse van wetgeving, rechtspraak en rechtsleer. Hierbij werd gebruikgemaakt van de courante zoekmotoren. Het onderzoek werd afgerond op 3 I augustus 2015 .

* Prof. dr. S. Lierman is hoofddocent administratief recht KU Leuven, deeltijds docent UAntwerpen. P.-J. Van de Weyer is assistent administratief recht KU Leuven. K.-J. Vandormael is assistent economisch recht KU Leuven, praktijkassistent UHasselt, advocaat Publius. 
Meteen zal duidelijk worden dat dit vraagstuk bij een analyse van het Belgische recht moeilijk kan worden losgekoppeld van de vraag naar het toepasselijke recht wanneer de overheid daadwerkelijk privaatrechtelijke technieken aanwendt.

3. Het mag misschien verwondering wekken dat de Belgische rechtspraak die uitdrukkelijk toepassing maakt of weigert van de tweewegenleer bijzonder schaars is. Voorbijgaand aan de vraag of de overheid in een bepaalde casus gebruik kan maken van de privaatrechtelijke weg, concentreert de discussie in rechtsleer en rechtspraak zich veelal meteen op het toepasselijke recht. Wanneer de overheid een beroep doet op de contractuele techniek, is deze overeenkomst in beginsel onderworpen aan het privaatrecht. Dit uitgangspunt wordt echter niet tot zijn uiterste consequenties doorgetrokken. De zuivere leer, die inhoudt dat overheidscontracten uitsluitend door het privaatrecht worden beheerst, doet de werkelijkheid oneer aan. Zelfs bij afwezigheid van een afwijkende wettelijke regeling zet de bijzondere aard van de rechtsverhouding de rechter er regelmatig toe aan om deze (deels) als reglementair te kwalificeren, i.h.b. bij het verstrekken van een openbare dienst. De welwillendheid waarmee dit gebeurt, staat in schril contrast met het gebrekkige referentiekader waarover de rechter hiertoe beschikt. Gelet op het belang van deze kwalificatie, gaan we in het tweede luik in op de rechtsgevolgen, alsook op de uiteenlopende criteria op basis waarvan deze beoordeling gebeurt (hoofdstuk 3).

4. Vervolgens nemen we een aantal specifieke overheidsovereenkomsten onder de loep, waarbij we nagaan op welke punten deze overeenkomsten een van het gemeen recht afwijkend statuut genieten (hoofdstuk 4). Onze aandacht gaat hierbij naar de concessie van openbare dienst, de domeinconcessie, de beheersovereenkomst en de beleidsovereenkomst, niet toevallig overeenkomsten waarvan het statuut vorm kreeg in de rechtspraak. Dit laat ons toe het rechterlijke toetsingskader te beoordelen. We laten aldus in dit preadvies de overeenkomsten buiten beschouwing waarvoor op grond van een uitdrukkelijke wettelijke regeling een bijzondere publiekrechtelijke regeling geldt. Omwille van dit bijzondere statuut in de rechtspraak maakt de rechtsleer doorgaans, zij het met de nodige nuance, een onderscheid tussen de administratieve contracten ('contrats administratifs') en de gewone overheidscontracten ('contrats de l'administration'). De afwijkingen houden in het bijzonder verband met de deels reglementaire kwalificatie van de rechtsverhouding, het overheidstoezicht, de eenzijdige wijzigbaarheid of beëindiging, de afwijking van contractuele sancties bij wanprestatie of de doorwerking van andere publiekrechtelijke regels en beginselen. Behoudens een aanvoelen dat zich in het algemeen belang een correctie op het gemeenrecht aandient, ontbreekt opnieuw echter een duidelijk normatief referentiekader.

5. In het laatste luik (hoofdstuk 5) gaan we na in hoeverre een publiekrechtelijke correctie noodzakelijk is om het algemeen belang en andere beschermingswaardige belangen te behartigen. In hoeverre biedt het privaatrecht hiertoe zelf reeds 
voldoende waarborgen? ${ }^{2}$ Op basis van het aansprakelijkheidsrecht en het recht dat de totstandkoming, de uitvoering en de beëindiging van overeenkomsten beheerst, bespreken we welke ruimte deze regels en beginselen bieden om deze belangen in rekening te nemen. Dit verhaal heeft duidelijk twee zijden die beide aandacht verdienen. Enerzijds staan op het eerste gezicht een aantal privaatrechtelijke rechtsregels en -beginselen haaks op de in het algemeen belang vooropgestelde prerogatieven van de overheid en de publiekrechtelijke beginselen, zoals de (ongeschreven) beginselen van de openbare dienst. Anderzijds biedt het aansprakelijkheids-, verbintenissen- en contractenrecht mogelijk ruimte voor een evenwichtige afweging van private en publieke belangen.

6. In het licht van de resultaten van dit (privaatrechtelijke) onderzoek, beoordelen we in een epiloog of het privaat- en publiekrecht vandaag in het overheidsovereenkomstenrecht optimaal worden ingezet tot behartiging van het algemeen belang. Om de verhouding tussen de privaat- en publiekrechtelijke regels scherp te stellen, maken we dankbaar gebruik van het in Nederland gehanteerde - en weliswaar verder genuanceerde - onderscheid tussen de zuivere, de gemene en de gemengde leer. ${ }^{3}$ Zoals de reeds geduide zuivere leer erkent de gemene leer de algemene gelding van het privaatrecht ook in verhoudingen van en met de overheid, zij het dat wordt aanvaard dat het publiekrecht hier in bepaalde gevallen van afwijkt. Het publiekrecht verhoudt zich dan als een bijzonder recht tot het gemeen privaatrecht. De gemengde leer erkent daarentegen dat eenzelfde verhouding wordt beheerst door normen die van origine zowel publiek- als privaatrechtelijk zijn. Het bestuursrecht wordt hierbij niet aanzien als een uitzonderingsrecht maar kent een steeds toenemende autonomie. In Nederland spitst de discussie zich hierbij steeds vaker toe op de vraag of de privaatrechtelijke regels op de verhouding met de overheid rechtstreeks dan wel slechts bij analogie van toepassing zijn. ${ }^{4}$

2 We zijn het pleidooi genegen van I. CLAEYS en L. CORNELIS, 'Het vergiftigde geschenk: elkeen wordt geacht de wet te kennen' in X. (eds.), Vereniging voor de vergelijkende studie van het recht van Belgie en Nederland: preadviezen 2014, Den Haag, Boom Juridische Uitgevers, 2014, 284: 'In alle takken van het publiek en het privaat recht is dringend fundamenteel onderzoek nodig om te bepalen waar de belangeninversie zich heeft voorgedaan en hoe daaraan kan worden verholpen. Geen rechtstak kan aan die oefening ontsnappen. De inversie heeft in elke rechtstak lelijk huisgehouden door het eigenbelang te laten betijen, zonder de impact op de samenleving, op termijn en bij veralgemening, (voldoende) in aanmerking te nemen'.

3 Zie over de evolutie van de verschillende opvattingen: L.F. WIGGERS-RUST, 'Roeien tegen de stroom in? Over de verhouding tussen privaatrecht en bestuursrecht?', NJB 2013, I374-1383.

4 S. LIERMAN, Besturen zonder grenzen. Over grijze zones en blinde vlekken, Acta Falconis, VIII, Antwerpen, Intersentia, 2015, 28. Zie voor Nederland: G. JURGENS en F. VAN OMMEREN, 'The public-private divide in English and Dutch law: a multifunctional and context-dependant divide', Cambridge Law journal 20I2, I92; H. D. VAN WIJK, W. KONIJNENBELT en R. VAN MALE, Hoofdstukken van bestuursrecht, Amsterdam, Reed Business, 20II, 406-408. Vgl.: M.W SCHELTEMA en M. SCHELTEMA, Gemeenschappelijk recht. Wisselwerking tussen publiek- en privaatrecht, Alphen aan den Rijn, Kluwer, 2008, 2-4; en A.Q.C. TAK, 'Overheid en Burgerlijk Wetboek, naar een invullende rechtsleer', R\&K I993, I74. 


\section{2 Tweewegenleer: vrij contracteren binnen publiekrechtelijke grenzen}

\section{I Belgische tweewegenleer: vrijheid, blijheid?}

7. Volgens de tweewegenleer heeft de overheid bij het behartigen van haar publieke doelstellingen in beginsel de keuzevrijheid om gebruik te maken van het privaatrecht in plaats van de publiekrechtelijke middelen die haar ter beschikking staan. Deze principiële keuzevrijheid is echter onderworpen aan een aantal grenzen. Zo mag de overheid niet a) in strijd handelen met dwingend recht of algemene rechtsbeginselen, b) de rechtzoekende essentiële waarborgen ontnemen, c) de eigen bevoegdheid of die van een andere overheid miskennen en d) de kern van de eigen beoordelingsvrijheid beperken. ${ }^{5}$ De overheid mag zich via de privaatrechtelijke techniek in geen geval ontdoen van de wezenlijke bestanddelen van het overheidsoptreden. Dit is bijvoorbeeld het geval wanneer de overheid zich een immuniteit toe-eigent waardoor de kern van haar verantwoordelijkheid wordt aangetast of haar beleidsvrijheid op onbeperkte wijze inperkt.

Deze in hoofdzaak publiekrechtelijke grenzen vervullen twee functies die moeilijk van elkaar te onderscheiden zijn. Enerzijds bakenen zij de grenzen af waarbinnen de overheid gebruik kan maken van het privaatrecht. Anderzijds geven deze voorwaarden aan hoe de overheid privaatrechtelijke technieken kan aanwenden ter behartiging van het algemeen belang. Omwille van die verwevenheid krijgt dit publiekrechtelijke kader waarin de overheid optreedt, ook wanneer zij de contractuele techniek hanteert, aandacht in de verschillende delen van dit preadvies. Het keurslijf waarin de overheid contracteert wordt in het bijzonder vormgegeven door het legaliteits- en het specialiteitsbeginsel, waaraan het bestuur zijn rechtsbekwaamheid ontleent, maar ook door de (minstens onrechtstreeks doorwerkende) beginselen van behoorlijk bestuur en de wetten van openbare dienst.

\subsection{Specialiteitsbeginsel: overheidsoptreden (doel)gebonden door het algemeen belang}

8. Overheden beschikken overeenkomstig het specialiteitsbeginsel slechts over de bevoegdheden die hen door of krachtens de (Grond)wet zijn toevertrouwd. Buiten die wettelijke taakvervulling waartoe ze is opgericht, mag de overheid geen andere

5 D. D'HOOGHE en F. VANDENDRIESSCHE, Publiek-Private Samenwerking, Brugge, Die Keure, 2003, I9, e.v.; K. LEUS, 'Overeenkomsten met de overheid en overheidsovereenkomsten: bijzondere overeenkomsten en algemeen belang. De 'gemene', de 'gemengde' of de 'zuivere' rechtsleer?' in X. (eds.), Bijzondere overeenkomsten, XXXIVe Postuniversitaire cyclus W. Delva, 2007-2008, Mechelen, Kluwer, 4I5-426; W. VAN GERVEN, De overheid in het verbintenissenrecht - Hoe blauw is het bloed van de prins?, Antwerpen, Kluwer, I984, 76; W. VAN GERVEN, Beleidsovereenkomsten. Academiae Analecta, Brussel, Paleis der Academiën, I984, 56; W. VAN GERVEN en M. WYCKAERT, 'Overeenkomsten met de overheid', TPR I987, I7I4. Volgens M. PAQUES daarentegen mag de overheid wanneer ze eenzijdig kan optreden slechts gebruikmaken van het privaatrechtelijk procedé wanneer de wet dit toelaat (M. PAQUES, 'Les conventions sectorielles en matière d'environnement du point de vue du droit public' in $\mathrm{H}$. BOCKEN en I. TRAEST (eds.), Milieuovereenkomsten, Brussel, Story Scientia, I99I, 65-66). 
doelstellingen nastreven. Dit beginsel is overigens niet beperkt tot de overheid, maar geldt ten aanzien van elke rechtspersoon, ongeacht zijn publiek- of privaatrechtelijke aard. Ook in het vennootschapsrecht geldt dat een rechtspersoon slechts kan handelen binnen het doel waarvoor hij werd opgericht, d.i. het doel zoals dat blijkt uit de statuten en de toepasselijke wetgeving.

9. Wat het oogmerk betreft, is de overheid bij het uitoefenen van haar bevoegdheid dus steeds (doel)gebonden. De overheid moet immers te allen tijde haar handelen kunnen kaderen binnen het algemeen belang waarvoor zij instaat. Dit betekent dat haar bevoegdheden slechts worden toegewezen ter verwezenlijking van een welbepaald doel. Zo handelen provincies en gemeenten in beginsel enkel ter behartiging van het provinciaal of gemeentelijk doel en dienen de gemeenschappen, de gewesten en de federale overheid binnen hun respectievelijke werkingssfeer op te treden. Concreet betekent dit dat een bestuur met toepassing van een bepaalde wetgeving niet elk aangebracht belang in zijn beoordeling kan meenemen. Bij de beoordeling van bijv. een stedenbouwkundige vergunningsaanvraag voor een lunapark, kan het bestuur geen rekening houden met de morele aspecten van de zaak, terwijl dat voor de klagende buren misschien net het breekpunt is. Hetzelfde beginsel geldt voor de talrijke dienstgewijs gedecentraliseerde instellingen zoals agentschappen en overheidsondernemingen.

Io. Machtsafwending, d.i. het gebruiken van een bevoegdheid voor een ander publiek of privaat doel dan datgene waarvoor zij is verleend, is verboden en leidt tot de onwettigheid van de bestuurshandeling die door de Raad van State kan worden gesanctioneerd (artikel I4 RvS-wet). Dit belet weliswaar niet dat de toegewezen bevoegdheden het bestuur vaak een (ruime) beleidsruimte laten. Deze discretionaire bevoegdheden staan tegenover de gebonden bevoegdheden waarbij het resultaat van het overheidshandelen afhankelijk is van de loutere toepassing van de wettelijke voorwaarden en procedures.

II. Het hoeft geen betoog dat dit beginsel geldt voor elk bestuursoptreden en dus niet enkel wanneer de overheid gebruikmaakt van haar bijzondere prerogatieven. Ook wanneer de overheid contracteert, moet zij het wettelijke doel dienen waartoe zij werd opgericht. Op grond van het specialiteitsbeginsel heeft een overheid niet alleen het recht, maar ook de verplichting om bij de uitoefening van de haar toekomende discretionaire bevoegdheden steeds rekening te houden met, en in te spelen op, de concrete noden van het algemeen belang. Het beginsel staat er weliswaar niet aan in de weg dat het algemeen belang steeds vaker (mede) wordt ingevuld door partnerschapsverhoudingen, publiek-private samenwerking en verzelfstandiging ${ }^{6}$, noch dat deze verzelfstandigde besturen naast hun kerntaak ook nevenopdrachten van commerciële aard vervullen. ${ }^{7}$ Wel staat deze verplichting op gespannen voet

6 Zie A. ALEN en W. DEVROE, 'Verzelfstandiging van bestuurstaken in België' in X. (eds.), Vereniging voor de vergelijkende studie van het recht van België en Nederland: preadviezen 1999, Deventer, Tjeenk Willink, I999.

7 I. CLEYMAET, S. VANDAMME en K. VANDERSCHOT, Praktisch administratief recht, Berchem, De Boeck, 2012, 38 . 
met een situatie waarin de overheid de inhoud van het eigen optreden of van de eigen beslissing op voorhand vastlegt. In een contractuele verhouding, waarin de overheid zich ertoe heeft verbonden in de toekomst een zekere prestatie te leveren of een bepaalde beslissing te nemen, lijkt het overkoepelende principe van de wilsautonomie immers juist te impliceren dat een aanpassing van de aangegane verbintenissen of een beëindiging van de overeenkomst om redenen van algemeen belang in principe enkel mogelijk is na wederzijdse instemming van de contractspartijen. Voor het overige geldt pacta sunt servanda (artikel II34 BW).

I2. Het voorgaande impliceert evenwel niet dat contracteren door de overheid per definitie haaks staat op de behartiging van het algemeen belang en om die reden onmogelijk zou zijn. Wel is het verboden voor de overheid om in een overeenkomst de kern van de eigen beoordelingsbevoegdheid te beperken. Dit is ook wat de afdeling wetgeving van de Raad van State overwoog in een advies bij het Vlaamse decreet betreffende milieubeleidsovereenkomsten van I5 juni I994, dat voorzag dat de regering zich ertoe zou kunnen verbinden geen gebruik te maken van haar bevoegdheid om, met betrekking tot de in de overeenkomst geregelde aangelegenheden, bij verordening strengere eisen te stellen. De afdeling wetgeving oordeelde dat 'dergelijke bevoegdheidsbeperkingen slechts toelaatbaar kunnen worden geacht indien voldoende waarborgen voorhanden zijn dat de overheid steeds kan optreden met het oog op de vrijwaring van het algemeen belang'. ${ }^{8}$ In een advies bij het Waalse Afvalstoffendecreet lijkt de afdeling wetgeving van de Raad van State zelfs nog een stap verder te gaan wanneer zij overweegt dat sectorovereenkomsten enkel mogelijk zijn wanneer 'le Gouvernement est, nonobstant la conclusion d'un contrat, en droit d'intervenir unilatéralement, à tout moment, par voie réglementaire lorsque l'intérêt général le requiert'. ${ }^{9}$ De mogelijkheid om te allen tijde in een contractuele relatie te kunnen ingrijpen ter vrijwaring van het algemeen belang vormt volgens deze redenering een wezenlijke voorwaarde voor het erkennen van de bevoegdheid van een bestuurlijke overheid om contractueel op te treden.

I3. Hieruit afleiden dat de overheid louter op grond van haar bijzondere positie te allen tijde gebruik moet kunnen maken van dit bijzondere prerogatief, zodanig dat zij eenzijdig kan terugkomen op contractuele verbintenissen, lijkt echter een brug te ver en doet afbreuk aan de ruimte die het privaatrecht hiertoe biedt. Het contract zelf kan immers voldoende waarborgen bevatten ter bescherming van het algemeen belang (zie hierover uitgebreid hoofdstuk 5 van dit preadvies). De overheid kan bijvoorbeeld korte opzegtermijnen of bevrijdingsclausules bedingen in geval van dringende gevallen of om te voldoen aan dwingende wettelijke verplichtingen.

I4. Een mooie illustratie van een toenemend vertrouwen in het privaatrecht in dit verband vormt het domeingoederenrecht. Goederen behorend tot het openbaar domein zijn exclusief voorbehouden voor het collectief gebruik of voor de uitoefening van een

Ontwerp van decreet betreffende de milieubeleidsovereenkomsten, Parl.St. Vl.Parl. 1992-93, nr. 40I/I, 58-59.

9 Project de décret relatif aux déchets, Parl.St. W.Parl. 1995, nr. 49/I, 59. 
openbare dienst. In de regel blijven dergelijke goederen dan ook buiten de handel. ${ }^{10} \mathrm{Het}$ Hof van Cassatie bevestigde in 2000 nog dat niemand bij overeenkomst private rechten kan verwerven op het openbaar domein wanneer hiermee het collectief gebruik zou kunnen worden belemmerd en afbreuk worden gedaan aan het recht van de openbare overheid om dit gebruik te allen tijde volgens de behoeften en het belang van alle burgers te regelen en te wijzigen. ${ }^{\text {II }}$ Een privatief gebruik van dergelijke goederen is met andere woorden enkel mogelijk voor zover de toegekende rechten precair en herroepbaar zijn. Om die reden wordt vaak de toevlucht gezocht tot de zogenoemde administratieve gebruiksrechten - domeinconcessies (overeenkomst) en domeinvergunningen (eenzijdige rechtshandeling) - die te allen tijde door de overheid kunnen worden gewijzigd of beëindigd (zie nr. 57 e.v.). Omdat dergelijk eenzijdig beëindigingsrecht of wijzigingsrecht in beginsel niet verenigbaar is met artikel $\mathrm{I}_{34} \mathrm{BW}$ bestond lange tijd de opvatting dat privaatrechtelijke gebruiksrechten per definitie niet konden worden verzoend met een bestemming van algemeen belang. Persoonlijke (huur) of zakelijke (vruchtgebruik, opstal, erfpacht, erfdienstbaarheid) rechten werden in abstracto uitgesloten. ${ }^{\mathrm{I2}}$

Dit rigide uitgangspunt wordt evenwel gestaag verlaten ten gunste van een meer functioneel kader waarbij de aanwezigheid van private rechtsfiguren in het domeingoederenrecht niet langer als problematisch hoeft te worden gezien. De eerste stap in deze richting werd gezet voor de erfdienstbaarheden. Waar voorheen erfdienstbaarheden op het openbaar domein nog duidelijk werden afgewezen, besloot het Hof van Cassatie in I990 dat een erfdienstbaarheid op een goed van het openbaar domein kan worden gevestigd op voorwaarde dat (I) zij niet onverenigbaar is met de openbare bestemming van dat domein, (2) ze geen beletsel vormt voor het openbaar gebruik en (3) ze geen afbreuk doet aan het recht van het bestuur om dat gebruik volgens de noden en het belang van de gemeenschap te regelen. ${ }^{13}$ Deze rechtspraak kreeg navolging voor de opstalrechten in 2007 en lijkt voorbestemd om te worden uitgebreid naar andere exclusieve gebruiks- en genotsrechten, zoals vruchtgebruik, erfpacht en huur. ${ }^{\text {I4 }}$

Ook de (Vlaamse) wetgever laat zich niet onbetuigd en voorziet op verscheidene plaatsen in een machtiging voor de bestuurlijke overheid om het openbaar domein te bezwaren met zakelijke rechten, wederom op voorwaarde dat de openbare bestemming van de goederen wordt geëerbiedigd. ${ }^{15}$

J. DUJARDIN, M. VAN DAMME, J. VANDE LANOTTE en A. MAST, Overzicht van het Belgisch administratief recht, Mechelen, Kluwer, 20I4, 328 e.v.; D. BATSELÉ, T. MORTIER en M. SCARCEZ, Algemeen administratief recht, Brussel, Bruylant, 20I2, 49r. Dit principe wordt evenwel bekritiseerd. Zie S. VAN GARSSE, De concessie in het raam van publiek-private samenwerking: een analyse van het openbaar en het privaat domein, van de domeinconcessies, de concessies van openbare werken, de concessies van diensten en hun aanbesteding, Brugge, Die Keure, 2007, 205.

II Cass. 25 september 2000, Arr.Cass. 2000, I428.

I2 V. SAGAERT, 'Opstal en openbaar domein: een doorbraak' (noot onder Cass. I8 mei 2007), RW 2007-08, 737 .

I3 Cass. 27 september 1990, Arr.Cass. I990-9I, 84.

I4 Cass. I8 mei 2007, C.06.0086.N. Zie voor een bespreking V. SAGAERT, 'Opstal en openbaar domein: een doorbraak' (noot onder Cass. I8 mei 2007), RW 2007-08, (737) 740.

I5 Zie bijvoorbeeld artikel Io PPS-decreet, artikel I9I Gem.Decr., artikel I85 Prov.Decr., artikel 7, \$2 Decreet houdende de oprichting van de NV van publiek recht BAM. 
Het abstracte verbod werd met andere woorden ingeruild voor een beoordeling in concreto van de verenigbaarheid van de toegekende persoonlijke of zakelijke rechten met het algemeen belang. Impliciet wordt hiermee duidelijk erkend dat ook wanneer de overheid gebruikmaakt van privaatrechtelijke rechtsfiguren, zij de mogelijkheid heeft, minstens de mogelijkheid kan voorzien, om in te grijpen in functie van het algemeen belang.

\subsection{Wettigheidsbeginsel en de algemene grondslag tot contracteren}

I5. Opdat de overheid rechtsgeldig optreedt, volstaat het niet dat zij binnen haar (grond)wettelijke bevoegdheidssfeer blijft. Zij zal bovendien conform het recht moeten handelen, d.i. op de door het hiërarchisch hogere recht voorgeschreven wijze. Beide vereisten vloeien voort uit het wettigheidsbeginsel.

Terwijl de wetgevende macht de volheid van bevoegdheid heeft, beschikt het bestuur slechts over de bevoegdheden die de (grond)wetgever haar uitdrukkelijk toewijst. Elk overheidshandelen moet dus een grondslag hebben in een wet of de Grondwet en het bestuur is verplicht daar uitvoering aan te geven, binnen een redelijke termijn en zonder de draagwijdte ervan te wijzigen. In die zin bepaalt artikel I05 van de Grondwet voor de federale uitvoerende macht dat de Koning geen andere macht heeft dan die welke de Grondwet en de bijzondere wetten, krachtens de Grondwet zelf uitgevaardigd, hem uitdrukkelijk toekennen. Artikel 33, lid 2 van de Grondwet bepaalt voorts dat alle machten worden uitgeoefend op de wijze bij de Grondwet bepaald. Omdat uit deze bepaling wordt afgeleid dat de overheidsbevoegdheden in beginsel onoverdraagbaar en onvervreemdbaar zijn, is delegatie ervan slechts toegelaten wanneer de wet hierin voorziet. Niettemin wordt ook bij afwezigheid van een uitdrukkelijke machtiging een bevoegdheidsoverdracht mogelijk geacht, voor zover dit gebeurt binnen het door het Hof van Cassatie gehanteerde delegatiekader. Het Hof beoordeelde in zijn standaardarrest van 4 mei 1920 een bevoegdheidsdelegatie als geoorloofd wanneer de delegatie detailmaatregelen betreft, het delegerend orgaan toezicht uitoefent op de wijze waarop de delegatie wordt uitgeoefend en de delegatie onmiddellijk herroepbaar is. ${ }^{16} \mathrm{Bij}$ de (contractuele) overdracht van bevoegdheden aan particulieren of private rechtspersonen moet dus bijzondere aandacht worden besteed aan de organisatie van het uit te oefenen toezicht. ${ }^{17}$ Volgens de Afdeling Wetgeving van de Raad van State is de private rechtsvorm echter onverenigbaar met de uitoefening van het 'klassieke' bestuurlijke toezicht. ${ }^{\text {8 }}$

I6 Cass. 4 mei I920, Pas. I920, I, I35, met concl. A-G DEMEURE.

I7 Het Hof van Cassatie stelt weliswaar niet elke overdracht van bevoegdheden gelijk aan een delegatie, getuige daarvan een arrest van 29 mei 2009 (C.08.0I29.N). In dit arrest oordeelde het Hof dat de gemeente die wettelijk gemachtigd was aan een particulier een concessie te geven voor de materiële organisatie van het betaald parkeren en hem de controle toe te vertrouwen van het naleven van het parkeerreglement, aldus niet haar bevoegdheid aan een derde delegeert maar een openbare dienst beheert op de wijze die haar het meest geschikt lijkt.

I8 Voorstel van decreet houdende oprichting van een Vlaams Fonds voor de Letteren, Parl.St. Vl.Parl. I998-99, nr. 988/2, Io. Zie ook F. VANDENDRIESSCHE, Publieke en private rechtspersonen. Naar een graduele, meerduidige en evolutieve benadering van het onderscheid in de wetgeving en de rechtspraak, Brugge, Die Keure, 2004, 36 en I48; S. BAETEN en F. VANDENDRIESSCHE, De bevoegdheidsverdeling in het federale België. Oprichting van rechtspersonen en participaties. Dienstgewijze decentralisatie (artikelen 9 en 96 BWHI), Brugge, Die Keure, 2007, 66. 
I6. Het spreekt voorts voor zich dat overheden bij al hun optreden, zowel reglementair als contractueel, de bevoegdheidsverdelende regels moeten respecteren. Zo zal bijv. het optreden van het Vlaamse gewest enkel mogelijk zijn binnen de materies waarvoor het gewest bevoegd is (materiële bevoegdheid), en binnen het territorium waarop het gewest zijn bevoegdheden mag uitoefenen (territoriale bevoegdheid). De wetgever bepaalt ook hoe het bestuur rechtsgeldig in het rechtsverkeer optreedt. De niet-naleving van deze regels heeft de onwettigheid van de overheidsbeslissing tot gevolg. Deze onwettigheid tast in principe ook de geldigheid van de overeenkomst aan.

Daarnaast wordt aangenomen dat overheidshandelen met (potentieel) budgettaire implicaties in overeenstemming moet zijn met het begrotingsrecht. Zo zullen de vereiste begrotingskredieten moeten worden ingeschreven en zal de (jaarlijkse) goedkeuring van de wetgevende macht vereist zijn ('annaliteits- en universaliteitsbeginsel'). De niet-naleving van de begrotingsregels (bijv. de ontstentenis van een toegestaan begrotingskrediet) tast echter de geldigheid van de verbintenis zelf niet aan, in tegenstelling tot wat het geval is bij de niet-naleving van de bevoegdheidsverdelende regels. Zo zal een overeenkomst gesloten door de overheid zonder machtiging in de begroting rechtsgeldig zijn en de overheid verbinden. De niet-naleving van begrotingsregels verhindert dan ook niet de uitvoering van de overeenkomst, alhoewel een en ander uiteraard kan leiden tot aansprakelijkheid.

I7. Het mag inmiddels duidelijk zijn dat eenzijdig optreden van de overheid slechts mogelijk is als zij daartoe door of krachtens de wet is gemachtigd. Het hoeft dus niet te verwonderen dat het wettigheidsbeginsel ook bepalend is bij de zoektocht naar alternatieve manieren waarop de overheid zich efficiënt (maar rechtsgeldig) kan verbinden.

Het contractuele optreden van de overheid staat geenszins ter discussie wanneer de wetgever zelf deze mogelijkheid voorziet. In tal van domeinen beschikt de overheid inderdaad over een uitdrukkelijke wettelijke bevoegdheid om te contracteren, zoals de mogelijkheid om in het raam van de overheidsopdrachtenwetgeving aannemingsovereenkomsten aan te gaan, beheers- of samenwerkingsovereenkomsten te sluiten of via de contractuele weg onroerende goederen te verwerven of te vervreemden, personeel aan te werven, een jachtrecht te gunnen of zakelijke rechten te vestigen. ${ }^{19}$

Maar ook bij stilzwijgen van de wetgever wordt aangenomen dat de overheid als rechtssubject over de algemene bekwaamheid beschikt om te contracteren, net zoals andere (privaatrechtelijke) rechtssubjecten. Deze opvatting steunt op artikel II 23 BW, dat bepaalt dat eenieder - dus ook de overheid - contracten kan aangaan indien

I9 K. LEUS, 'Overeenkomsten met de overheid en overheidsovereenkomsten: bijzondere overeenkomsten en algemeen belang. De 'gemene', de 'gemengde' of de 'zuivere' rechtsleer?' in X. (eds.), Bijzondere overeenkomsten, XXXIVe Postuniversitaire cyclus W. Delva, 2007-2008, Mechelen, Kluwer, 4I34I4. 
hij daartoe door de wet niet onbekwaam is verklaard. ${ }^{20}$ De rechtsleer vindt in dat artikel dan ook de algemene wettelijke grondslag voor de overheid om contracten te sluiten. ${ }^{21}$ Een meer specifieke wettelijke machtiging is hiertoe niet vereist. ${ }^{22}$

Deze gedachtegang wordt in de rechtspraak echter niet gevolgd m.b.t. de mogelijkheid voor de overheid om privaatrechtelijke rechtspersonen op te richten of er een deelname in te verkrijgen. Zo weigerden de Raad van State en het Hof van Cassatie herhaaldelijk de mogelijkheid daartoe te erkennen voor gemeenten bij gebrek aan een bijzondere wettelijke grondslag. ${ }^{23}$ Het gebruik van de private rechtsvorm verplicht de overheid er overigens toe om de essentiële en dwingende bepalingen van de vennootschapswetgeving te respecteren. ${ }^{24}$ In essentie mag de overheid de gekozen vennootschapsvorm niet 'denatureren'. 25

\subsection{Troebel water: het ene overheidscontract is het andere niet}

I8. Wanneer de overheid de contractuele weg bewandelt, zijn deze contracten gesloten door de overheid in principe onderworpen aan het privaatrecht. Het bestuur zou in dit geval de overeenkomst enkel op eenzijdige wijze kunnen beëindigen of wijzigen indien het daartoe door de wet is gemachtigd of indien de overeenkomst zelf in die mogelijkheid voorziet. Dit privaatrechtelijke uitgangspunt wordt echter niet tot in zijn uiterste consequenties doorgetrokken. Tal van overeenkomsten waarbij de overheid als contractspartij optreedt, zijn wel degelijk onderworpen aan afwijkende publiekrechtelijke regels en beginselen. Vaak is deze bijzondere regeling verankerd in wetgeving, maar ook bij stilzwijgen van de wetgever kent de rechter zelf aan bepaalde overeenkomsten een bijzonder statuut toe en kwalificeert hij een rechtsverhouding als reglementair i.p.v. contractueel. Dit in de rechtspraak ontwikkelde regime maakt het voorwerp uit van het derde en het vierde hoofdstuk van dit preadvies.

20 Artikel II23 BW heeft echter betrekking op de handelings- en rechtsbekwaamheid van het rechtssubject, maar zegt niets over het overheidsorgaan dat rechtsgeldig contracten kan sluiten (bevoegdheid).

2I Zie hierover: D. D'HOOGHE, 'Overeenkomsten met de overheid' in X. (eds.), De overeenkomst vandaag en morgen, Antwerpen, Kluwer, I990, I34-I35. Zie echter kritisch over deze grondslag en de impliciete bevestiging van deze algemene bevoegdheid tot contracteren in o.m. de artikelen I596, I7I2 en 2054 BW: K. LEUS, 'Overeenkomsten met de overheid en overheidsovereenkomsten: bijzondere overeenkomsten en algemeen belang. De 'gemene', de 'gemengde' of de 'zuivere' rechtsleer?’ in X. (eds.), Bijzondere overeenkomsten, XXXIVe Postuniversitaire cyclus W. Delva, 2007-2008, Mechelen, Kluwer, 4I0-4I3.

22 D. D'HOOGHE en F. VANDENDRIESSCHE, Publiek-private samenwerking, Brugge, die Keure, 2003, 22-23.

23 Zie o.m. RvS 2I januari I994, nr. 457I6, asbl Centre Hospitalier De Soignies; RvS I5 september I992, nr. 40314, Driessens en cons.; Cass. I4 oktober 2002, met noot F. VANDENDRIESSCHE, 'De oprichting van een intergemeentelijke vereniging op grond van de vzw-wet en de burgerlijke rechter', CDPK 2003, Io6 e.v. Deze rechtspraak is niet vrij van kritiek (D. D'HOOGHE en F. VANDENDRIESSCHE, Publiek-private samenwerking, Brugge, die Keure, 200I, I34-I52).

24 Zie bijv. Parl. St. Vl. Parl. I990-I99I, nr. 488/2, I5-I6 en Parl. St. Vl. Parl. I993-I994, nr. 556/I, I70I7I. Zie daarover F. VANDENDRIESSCHE, Publieke en Private Rechtspersonen ? Naar een graduele, meerduidige en evolutieve benadering van het onderscheid in de wetgeving en de rechtspraak, Brugge, Die Keure, 2004, I27.

25 Zie A. ALEN en W. DEVROE, 'Verzelfstandiging van bestuurstaken in België' in X. (eds.), Vereniging voor de vergelijkende studie van het recht van België en Nederland: preadviezen 1999, II8 e.v. 
I9. Om die reden maakt de rechtsleer bij het meerzijdig optreden van de overheid naar Frans voorbeeld een onderscheid tussen administratieve contracten ('contrats administratifs') en overeenkomsten met de overheid ('contrats de l'administration'). ${ }^{26}$ Volgens die logica worden de 'gewone' overeenkomsten met de overheid, zoals koop, verkoop of huur, beheerst door het gemeen verbintenissenrecht, terwijl voor de administratieve contracten afwijkende regels gelden omdat zij betrekking hebben op de behartiging van het algemeen belang. Van dit laatste is in het bijzonder sprake wanneer de overeenkomst betrekking heeft op een openbare dienst (concessie van openbare dienst) of het gebruik van het openbaar domein (domeinconcessie). Het onderscheid wordt verklaard vanuit de opvatting dat de overheid bij gewone contracten op gelijke voet staat met haar medecontractant, terwijl bij de administratieve contracten de ongelijkheid tussen contractspartijen de regel is omdat het algemeen belang voorrang moet krijgen op het individuele belang van de medecontractant.

20. Het gaat echter te ver om uit het sui generis-karakter van bepaalde overheidsovereenkomsten af te leiden dat het Belgische recht net zoals Frankrijk een algemene theorie van het administratief contract kent, waarbij de administratieve contracten onderworpen zijn aan een volledig van het privaatrecht onderscheiden regelenbestand. ${ }^{27}$ In de rechtsleer wordt er vooreerst op gewezen dat verschillende van de exorbitante overheidsbevoegdheden in het raam van administratieve overeenkomsten kunnen (en moeten) worden verklaard door gebruik te maken van een privaatrechtelijk redeneerschema. ${ }^{28}$ Bovendien steunt de beschreven indeling op het in België reeds lang verlaten onderscheid tussen de Staat als privépersoon en de Staat als openbare macht, waardoor een rechtsgrondslag niet voorhanden lijkt. ${ }^{29}$ Reeds in het befaamde Flandria-arrest van 1920 huldigde het Hof van

26 A. BUTTGENBACH, Manuel de droit administratif, Brussel, Larcier, I966, 355; F. DE VISSCHERE, 'Algemene theorie der rechtshandelingen van het openbaar bestuur', RW I96I-62, 2394; A. MAST, J. DUJARDIN, M. VAN DAMME en J. VANDE LANOTTE, Overzicht van het Belgisch administratief recht, Mechelen, Kluwer, 20I4, I64 e.v.; W. VAN GERVEN en M. WYCKAERT, 'Overeenkomsten met de overheid', TPR I987, I7I4 (volgens deze laatste auteurs is er slechts sprake van een gradatieverschil); contra: S. BAETEN, P. DE BOCK, K. LEMMENS, J. OLIVIER, K. LEUS, 'Enige bedenkingen omtrent het juridisch kader van de convenanten', T.Gem. 200I, 20-2I; C. CAMBIER, Droit administratif, Brussel, Larcier, I968, 272; L. WAUTHIER, 'Y-a-t-il en droit belge, des contrats administratifs?', JT I956, 65; D. D'HOOGHE, 'Overeenkomsten met de overheid' in M. STORME, Y. MERCHIERS en J. HERBOTS (eds.), De overeenkomst. Vandaag en morgen, Antwerpen, Kluwer, I990, I3I.

27 S. LIERMAN, Besturen zonder grenzen. Over grijze zones en blinde vlekken, Acta Falconis, VIII, Antwerpen, Intersentia, 2015, I4, e.v.; zie ook D. D'HOOGHE, 'Overeenkomsten met de overheid' in M. STORME, Y. MERCHIERS en J. HERBOTS (eds.), De overeenkomst. Vandaag en morgen, Antwerpen, Kluwer, I990, I32.

28 D. D'HOOGHE, 'Overeenkomsten met de overheid' in M. STORME, Y. MERCHIERS en J. HERBOTS (eds.), De overeenkomst. Vandaag en morgen, Antwerpen, Kluwer, I990, I54, e.v. De auteur wijst er ook op dat de theorie van het administratief contract moeilijk verenigbaar is met de tweewegenleer die de overheid de keuzemogelijkheid laat maar waarbij zij dan ook de gevolgen van die keuze moet dragen (kiezen is verliezen) (p. I56). Zie ook bijv. wat het veranderlijkheidsbeginsel in het kader van domeinconcessies betreft: S. VAN GARSSE, De concessie in het raam van publiek-private samenwerking: een analyse van het openbaar en het privaat domein, van de domeinconcessies, de concessies van openbare werken, de concessies van diensten en hun aanbesteding, Brugge, Die Keure, 2007, 295 ev.

29 D. D'HOOGHE, 'Overeenkomsten met de overheid' in M. STORME, Y. MERCHIERS en J. HERBOTS (eds.), De overeenkomst. Vandaag en morgen, Antwerpen, Kluwer, I990, I55. 
Cassatie de opvatting dat er bij de toepassing van het recht principieel geen onderscheid meer kan worden gemaakt tussen de overheid die optreedt 'als overheid' en de overheid die optreedt 'als privépersoon' en dat zodoende iedereen - m.i.v. de overheid - onderworpen is aan dezelfde (aansprakelijkheids)regels. ${ }^{\circ}$ Overigens houdt het (eerder besproken) specialiteitsbeginsel in dat het overheidshandelen steeds doelgebonden is. Bij alle overheidscontracten zal de overheid dus steeds het algemeen belang moeten nastreven. Evenmin overtuigt de verantwoording dat administratieve contracten steunen op de ongelijkheid van contractspartijen en daarom afwijkend moeten worden behandeld. Ook in het gemeen verbintenissenrecht staan contractspartijen niet altijd op gelijke voet, getuige daarvan de ontstaansreden en de verdere ontwikkeling van het consumentenrecht.

Het Belgische bestuursrecht kent bovendien in vergelijking tot het Franse recht niet dezelfde autonomie doordat het rechterlijke toezicht op de overheid verdeeld is onder de bestuursrechter en de gewone rechter en uitsluitend deze laatste bevoegd is om uitspraak te doen over subjectieve rechten, met inbegrip van geschillen aangaande rechten en verplichtingen van contractspartijen. De rechtsmacht van de gewone rechter strekt zich derhalve uit tot alle overheidscontracten, ongeacht hun gewone of bijzondere statuut. Het wekt daarom weinig verwondering dat de burgerlijke rechter hierbij bij voorrang het recht toepast waarmee hij het best vertrouwd is, met name het privaatrecht. ${ }^{3 \mathrm{I}}$

Een vaak gehoord argument tegen het gebruik van de contractuele techniek houdt precies verband met dit verschil in rechtsbescherming. Het objectieve contentieux van de bestuursrechter laat immers toe dat eenieder die doet blijken van een persoonlijk, actueel en rechtstreeks belang een vernietigingsberoep kan instellen tegen een uitvoerbare administratieve rechtshandeling. Deze vernietiging leidt er dan toe dat de onwettige bestuurshandeling ex tunc en erga omnes uit de rechtsorde verdwijnt. De bestuursrechter ontbeert deze bevoegdheid t.a.v. overheidscontracten. De algemene bevoegdheid van de gewone rechter om uitspraak te doen over subjectieve (en dus ook contractuele) rechten, verhindert echter niet dat het toezicht van de Raad van State zich uitstrekt tot de totstandkoming van contractuele overheidshandelingen..$^{32}$ Volgens het zogenoemde leerstuk van de afsplitsbare bestuurshandelingen kunnen bestuurshandelingen die de overheidsovereenkomst voorafgaan of erop volgen,

Cass. 4 november 1920, Pas. I920, I, 20I; zie ook de conclusie van A-G P. LECLERCQ: 'le gouvernement ou le pouvoir exécutif, agissant à ce titre de pouvoir exécutif, passe des contrats et n'est pas, à ce titre, hors le droit civil' (Pas. I920, I, I93).

3I S. LIERMAN, Besturen zonder grenzen. Over grijze zones en blinde vlekken, Acta Falconis, VIII, Antwerpen, Intersentia, 2015, I4, e.v.

32 Bestuurshandelingen die de overheidsovereenkomst voorafgaan of erop volgen, kunnen wel het voorwerp uitmaken van een nietigheidsberoep bij de Raad van State. Hierdoor strekt het toezicht van de Raad van State zich uit tot de totstandkoming van contractuele overheidshandelingen (F. VANDENDRIESSCHE, Publieke en private rechtspersonen. Naar een graduele, meerduidige en evolutieve benadering van het onderscheid in de wetgeving en de rechtspraak, Brugge, Die Keure, 2004, Io6; K. LEUS, 'Overeenkomsten met de overheid en overheidsovereenkomsten: bijzondere overeenkomsten en algemeen belang. De "gemene”, de “gemengde” of de “zuivere” rechtsleer?' in X. (eds.), Bijzondere overeenkomsten, XXXIVe Postuniversitaire cyclus W. Delva, 2007-2008, Mechelen, Kluwer, 4I8). 
immers het voorwerp uitmaken van een nietigheidsberoep bij de Raad van State. Hierover hebben we het meer uitgebreid in het volgende hoofdstuk. De vraag in hoeverre ook via het privaatrecht en het subjectieve contentieux belangen van derden afdoende kunnen worden beschermd, komt aan bod in het vijfde hoofdstuk.

In Frankrijk is uitsluitend de bestuursrechter bevoegd om uitspraak te doen over administratieve contracten. Het afwijkende publiekrechtelijke regime geldt er voor de totstandkoming, de uitvoering en de beëindiging van deze bijzondere categorie van overheidscontracten. De Franse benadering vertrekt vanuit het bijzondere statuut van de overheid, waardoor publiekrechtelijke rechtsregels in principe gelden in elke verhouding, ongeacht of deze reglementair dan wel contractueel is. ${ }^{33}$ Het Belgische recht kent daarentegen meer gewicht toe aan het privaatrechtelijke rechtsinstrument dan aan de publiekrechtelijke titularis die deze bevoegdheid uitoefent. ${ }^{34}$ Zelfs bij de zogenoemde administratieve contracten ligt de klemtoon op het contractuele element en geldt het publiekrecht als correctie op het principieel toepasselijke privaatrecht. Anders dan in Frankrijk maakt het bijzondere regime van deze categorie van overheidscontracten dan ook geen sluitend (van het gemeen recht afwijkend) geheel uit, maar krijgt het ad hoc en op pragmatische wijze vorm in de rechtspraak. ${ }^{35}$

\subsection{Onzekere werkingssfeer van de ongeschreven beginselen van behoorlijk bestuur}

2I. De beginselen van behoorlijk bestuur zijn het geheel van beginselen die aangeven hoe en op welke manier bestuursbeslissingen moeten worden genomen en omkaderd. Zeworden door de rechter 'afgeleid' of 'gevonden' in het rechtssysteem, en zijn bindend voor het bestuur. ${ }^{36}$ Het gaat om concrete gedragsvoorschriften met een positiefrechtelijk karakter, waarvan de naleving door de rechter kan worden gecontroleerd. ${ }^{37}$ Deze beginselen van behoorlijk bestuur functioneren in essentie

33 Voor de kwalificatie als administratieve overeenkomst volstaat het weliswaar niet dat een publieke rechtspersoon optreedt als contractspartij. Hiervan is slechts sprake als de overeenkomst of de wetgeving de overheid van het gemeen recht afwijkende bevoegdheden toekent of als de overeenkomst een voldoende nauwe band heeft met de uitoefening van de openbare dienst. Zie voor de afbakening van dit begrip: C. GUETTIER, Droit des contrats administratifs, Parijs, Presses Universitaires de France, 2004, 75-I40.

34 S. LIERMAN, Besturen zonder grenzen. Over grijze zones en blinde vlekken, Acta Falconis, VIII, Antwerpen, Intersentia, 2015, I4 e.v.

35 A. MAST, J. DUJARDIN, M. VAN DAMME en J. VANDE LANOTTE, Overzicht van het Belgisch administratief recht, Mechelen, Kluwer, 20I4, I65.

36 A. MAST, J. DUJARDIN, M. VAN DAMME en J. VANDE LANOTTE, Overzicht van het Belgisch administratief recht, Mechelen, Kluwer, 20I4, 48 e.v. Zie voor een gedetailleerde bespreking I. OPDEBEEK en M. VAN DAMME (eds.), Beginselen van behoorlijk bestuur, Brugge, Die Keure, 2006, 49Ip. Zie daarover ook G.J. WIARDA, 'Algemene beginselen van behoorlijk bestuur in het Nederlandse recht', TBP I970, 365-378; L.-P. SUETENS, 'Algemene rechtsbeginselen en algemene beginselen van behoorlijk bestuur in het Belgisch administratief recht', TBP I970, 379-396.

37 P. VAN ORSHOVEN, 'Algemene rechtsbeginselen, in alle rechtstakken' in X. (eds.), Postuniversitaire cyclus Willy Delva. XXIII: De doorwerking van het publiekrecht in het privaatrecht, Gent, Mys \& Breesch, I997, Io; P. VAN ORSHOVEN, 'Non scripta, sed nata lex' in M. VAN HOECKE (ed.), Algemene rechtsbeginselen, Antwerpen, Kluwer, I99I, 69-73. 
als beperking van de (discretionaire) bevoegdheid van het bestuur (daar waar de beginselen van de openbare dienst in essentie dienen ter verruiming van de bevoegdheden van het bestuur, zie nr. 27 e.v.).

22. Over het toepassingsgebied van de beginselen van behoorlijk bestuur is in België al veel geschreven. ${ }^{38}$ Er bestaat eensgezindheid over het feit dat deze beginselen van toepassing zijn op het eenzijdig overheidsoptreden (reglementaire rechtsverhoudingen). ${ }^{39} \mathrm{Om}$ deze reden wordt de rechtstreekse toepasselijkheid eveneens algemeen aanvaard in de fase van de totstandkoming van een overheidsovereenkomst. De Raad van State beschouwt de beslissing tot contractsluiting immers als een afsplitsbare (eenzijdige) rechtshandeling die onderworpen is aan de beginselen van behoorlijk bestuur..$^{\circ}$ Zo zijn bijv. de regels inzake transparantie, objectieve en gelijke behandeling en het verbod van willekeur van toepassing, ongeacht of een personeelslid contractueel of statutair wordt aangesteld of een openbare dienst via contractuele weg of bij een eenzijdig overheidsbesluit wordt uitbesteed. ${ }^{4}$

23. De theorie van de afsplitsbare rechtshandeling - die restrictief dient te worden uitgelegd - geldt echter niet in het raam van de uitvoering en de beëindiging van

38 Zie o.a. K. WAUTERS, 'Zin of onzin van een leer van het administratief contract in België?' in D. D'HOOGHE, K. DEKETELAERE en A.M. DRAYE (eds.), Liber amicorum Marc Boes, Brugge, Die Keure, 20II, 589-6o6; P. POPELIER, 'Beginselen van behoorlijk bestuur: begrip en plaats in de hiërarchie van de normen' in I. OPDEBEEK en M. VAN DAMME (eds.), Beginselen van behoorlijk bestuur, Brugge, Die Keure, 2006, 4-5; J. DE STAERCKE, Algemene beginselen van behoorlijk bestuur, Mechelen, Kluwer, 2004, 9-I3; J. DE STAERCKE, Algemene beginselen van behoorlijk bestuur en behoorlijk burgerschap: beginselen van de openbare dienst, Brugge, Vanden Broele, 2002, I4-I5. Zie ook W. VAN GERVEN, 'Algemene beginselen van behoorlijk handelen', RW I982-83, 962-978, die stelt dat deze beginselen eigenlijk een specifieke verschijningsvorm zijn van bredere algemene rechtsbeginselen, nl. de 'algemene beginselen van behoorlijk handelen'; in dezelfde zin: F. VANDENDRIESSCHE, 'Het toepassingsgebied van de beginselen van behoorlijk bestuur' in I. OPDEBEEK en M. VAN DAMME (eds.), Beginselen van behoorlijk bestuur, Brugge, Die Keure, 2006, 39; G.M.A. VAN DER HEIJDEN, Een filosofie van behoorlijk bestuur, Deventer, W.E.J. Tjeenk Willink, 200I, 2; M. VAN DAMME, 'Goede trouw van burger en bestuur', RW I989-I990, IIo8IIO9; F. DEBAEDTS, 'De algemene rechtsbeginselen in het administratief recht', TBP I988, 644. Zie ook K. WAUTERS, Rechtsbescherming en overheidsovereenkomsten, Antwerpen, Intersentia, 2009, I37-I43.

39 Een bijkomend probleem in dat opzicht, naast de kwestie van het eigenlijke toepassingsgebied van de beginselen van behoorlijk bestuur, vormt het feit dat het zeker niet altijd even gemakkelijk is om een orgaan al dan niet te kwalificeren als een bestuurlijke overheid (S. DE SOMER, 'Het begrip administratieve overheid: stand van zaken van a never ending story', RW 20II-20I2, I6I4I639; J. DE STAERCKE, 'Wat is een administratieve overheid? De cassatiearresten van 6 september 2002', TBP 2003, 64; V. VERDEYEN, 'Administratieve overheden; een organieke nuancering van de functionele benadering', CDPK 2006, 325).

40 RvS 17 juni 2003, nr. I20.646, NV Pac man; RvS 28 mei 1997, nr. 66.428, BVBA De Backer; RvS 2 februari I993, nr. 4I.878, NV Seaport Terminals; RvS 3I mei I979, nr. I9.67I, Integan.

4I K. LEUS, 'Overeenkomsten met de overheid en overheidsovereenkomsten: bijzondere overeenkomsten en algemeen belang. De 'gemene', de 'gemengde' of de 'zuivere' rechtsleer?' in X. (eds.), Bijzondere overeenkomsten, XXXIVe Postuniversitaire cyclus W. Delva, 2007-2008, Mechelen, Kluwer, 4I5-426. 
de overeenkomst. ${ }^{2}$ De rechtstreekse doorwerking van beginselen van behoorlijk bestuur in deze fase maakt dan ook het voorwerp uit van discussie, zowel in de rechtspraak als de rechtsleer.

Zo wordt in rechtspraak over arbeidsovereenkomsten afgesloten tussen de overheid en haar contractuele personeelsleden nu eens beslist dat de rechtsverhouding rechtstreeks en onverkort is onderworpen aan de beginselen van behoorlijk bestuur, ${ }^{43}$ maar wordt in andere gevallen een rechtstreekse doorwerking van de beginselen van behoorlijk bestuur expliciet afgewezen. ${ }^{44}$

24. Ook in de rechtsleer bestaat onenigheid over het toepassingsbereik van deze beginselen. Zo verdedigen verscheidene auteurs de enkele toepassing op de reglementaire rechtsverhouding met het argument dat deze beginselen het tegengewicht vormen voor de (soms ruime) eenzijdige overheidsbevoegdheden. ${ }^{45}$ Anderen stellen dan weer dat de beginselen van behoorlijk bestuur steeds gelden in 'rechtsverhoudingen die kaderen binnen het algemeen belang' of die strekken tot het uitoefenen van een 'doelgebonden bevoegdheid (die tot het algemeen belang strekt)' ${ }^{6}$ of een 'taak van algemeen belang' ${ }^{47}$ De rechtspraak gebruikt deze criteria ook sporadisch in de zeldzame

42 RvS 7 november 2013, nr. 225.385, NV Kinepolis Mega: 'De theorie van de afsplitsbare rechtshandeling heeft voornamelijk betrekking op de rechtshandelingen in verband met de totstandkoming van een overeenkomst. Eenmaal de overeenkomst is gesloten, zullen geschillen omtrent de uitvoering, interpretatie en ontbinding van die overeenkomst door de justitiële rechter moeten worden beslecht.' Zie meer concreet RvS 25 februari 20I4, nr. 226.533, NV Bimexco (beëindiging overheidsopdracht), RvS I4 juli 20II, nr. 2I4.638, Calant (beëindiging arbeidsovereenkomst). Zie tevens D. D'HOOGHE, 'Overeenkomsten met de overheid' in X. (eds.), De overeenkomst vandaag en morgen, Antwerpen, Kluwer, I990, I49. Zie echter verder over de domeinconcessie nr. 59 .

43 Arbh. Brussel 8 januari 20I3, JTT 20I3, 228; Arbh. Brussel 23 april 20I2, JTT 20I2, 284; Arbh. Brussel I3 december 20II, Soc.Kron. 2013, 392; Arbh. Luik, 20 juni 20II, Soc.Kron. 20I3, 37I; Arbh. Luik 22 december 2010, Soc.Kron. 2013, 368 (volgens een merkwaardige redenering stelt het Hof i.c. dat een eenzijdige beslissing tot verbreking van de (arbeids)overeenkomst enkel dan een bestuurshandeling is in de zin van de Wet Motivering Bestuurshandelingen wanneer deze beslissing schriftelijk genomen werd); Arbh. Brussel I8 december 2008, JTT 2009, I53; Arbh. Brussel 27 november 2007, JTT 2008, I67; Arbh. Brussel 9 november 2007, JTT 2008, 73; Arbh. Brussel 1o december 2003, JTT I85; Arbrb. Brussel 30 oktober 2000, JTT 200I, 52; Arbrb. Brussel 25 mei 20II, JTT 20II, 473; Arbrb. Bergen io januari 20II, JTT 2012, I0.

44 Arbh. Gent I3 februari 2013, Soc.Kron. 2013, 366; Arbh. Luik 5 september 2012, Soc.Kron. 2013, 378; Arbh. Antwerpen 20 april 2009, Soc.Kron. 2013, 355; Arbh. Luik 24 juni 2009, JTT 20I0, I3; Arbrb. Tongeren 2 oktober 2008, Limb.Rechtsl. 2010, 225; Arbrb. Gent 6 december 2007, RW 2007o8, I480, noot K. SALOMEZ.

45 P. POPELIER, 'Beginselen van behoorlijk bestuur: begrip en plaats in de hiërarchie van de normen' in I. OPDEBEEK en M. VAN DAMME (eds.), Beginselen van behoorlijk bestuur, Brugge, die Keure, 2006, 20; A. DE BECKER, De overheid en haar personeel: juridische grondslagen van de rechtspositie van de ambtenaar, Brugge, die Keure, 2007, 577-58I; A. DE BECKER, 'De motivering van het ontslag van een arbeidscontractant in de publieke sector', RW 2007-08, afl. 3, Ioo.

46 J. DE STAERCKE, Algemene beginselen van behoorlijk bestuur, Mechelen, Kluwer, 2004, 9-I3; J. DE STAERCKE, Algemene beginselen van behoorlijk bestuur en behoorlijk burgerschap: beginselen van de openbare dienst, Brugge, Vanden Broele, 2002, I2-I3. Voor kritiek zie F. VANDENDRIESSCHE, 'Het toepassingsgebied van de beginselen van behoorlijk bestuur' in I. OPDEBEEK en M. VAN DAMME (eds.), Beginselen van behoorlijk bestuur, Brugge, Die Keure, 2006, 43-44.

47 Zie W. VAN GERVEN en M. WYCKAERT, 'Overeenkomsten met de overheid', TPR I987, I7I6. 
uitspraken hierover..$^{8}$ Een verdienstelijke poging tot concretisering van het toepassingsgebied van de beginselen van behoorlijk bestuur werd ook ondernomen door F. Vandendriessche. Deze auteur stelt voor om de toepassing van de beginselen van behoorlijk bestuur af te bakenen aan de hand van een dubbel criterium. Volgens zijn opvatting zijn de beginselen van behoorlijk bestuur van toepassing op: (a) alle handelingen van 'organieke' overheden, d.w.z. instellingen opgericht of erkend door de overheid en belast met een taak van algemeen belang ${ }^{49}$; en (b) 'gezagshandelingen' en handelingen ingebed in een 'publiekrechtelijk procedé'. ${ }^{\circ}$ Elk van deze voorstellen roepen echter nieuwe vragen en afbakeningsproblemen op. . $^{\text {I }}$

25. De voorgaande discussie geldt uiteraard niet voor die beginselen die een concretisering vormen van de grondrechten. Het is immers onbetwist dat een overheid niet alleen voor haar eenzijdig optreden, maar eveneens in het kader van haar privaat handelen, steeds de (publiekrechtelijke) grondrechten dient na te leven. ${ }^{52} \mathrm{We}$ denken hier dan bij uitstek aan het gelijkheidsbeginsel.

26. Het belang van de discussie over de rechtstreekse doorwerking van beginselen van behoorlijk bestuur in de private rechtsverhoudingen van de overheid moet overigens worden genuanceerd. Meer eensgezindheid bestaat er immers over de onrechtstreekse doorwerking van deze principes op de overheidscontracten via de open normen in het privaatrecht. ${ }^{53}$ In hoofdstuk 5 bespreken we in dit verband of, en

48 Zie bijv. Vred. Leuven, 3 mei 2000, RW 2002-2003, 272-273; Vred. Ciney 9 november I988, RRD, I989, 322-325. De toepasselijkheid van de beginselen van behoorlijk bestuur werd in beide gevallen gemotiveerd door te verwijzen naar het vervullen van de openbare dienst met het oog op het algemeen of maatschappelijke belang van de organisatie (i.c. sociale huisvestingsmaatschappijen).

49 De auteur voorziet slechts één uitzondering, namelijk indien de regelgever zelf een onderscheid maakt tussen een optreden als overheid en louter private of commerciële activiteiten, zoals dit het geval is voor de handelingen van de federale economische overheidsbedrijven krachtens de wet van 2I maart I99I (F. VANDENDRIESSCHE, 'Het toepassingsgebied van de beginselen van behoorlijk bestuur' in I. OPDEBEEK en M. VAN DAMME, Beginselen van behoorlijk bestuur, Brugge, Die Keure, 2006, 56).

50 Met 'gezagshandelingen' bedoelt VANDENDRIESSCHE de imperiumbevoegdheid (d.i. de eenzijdige beslissingsmacht t.a.v. derden); met 'publiekrechtelijk procedé' wordt bedoeld een door de wetgever specifiek uitgewerkt regime (zoals bijv. de wetgeving m.b.t. overheidsopdrachten). Zie F. VANDENDRIESSCHE, 'Het toepassingsgebied van de beginselen van behoorlijk bestuur' in I. OPDEBEEK en M. VAN DAMME (eds.), Beginselen van behoorlijk bestuur, Brugge, Die Keure, 2006, $44-65$.

5I Meer fundamenteel wordt in deze laatste opvatting één vaag criterium ('taak van algemeen belang') vervangen door drie subcriteria, die zo mogelijk nog vager zijn (de begrippen 'organieke overheid' en 'gezagshandelingen', maar vooral ook het begrip 'ingebed in een publiekrechtelijk procédé', laten aan duidelijkheid te wensen over). Zie daarover K.-J. VANDORMAEL, 'Overheidswaarborgen en ABBB', CDPK, te verschijnen. Evenmin lijkt het Hof van Cassatie deze opvatting te delen (zie bijv. Cass 2I maart I994, Soc.Kron. 1994, I6I-I62).

52 A. VAN OEVELEN, 'De contractuele versus de reglementaire rechtsverhouding tussen openbare nutsbedrijven en hun gebruikers, en de rechterlijke toetsing van de in die rechtsverhouding gehanteerde exoneratieclausules' (noot onder Cass. 4 december 2000), RW 2002-2003, I579.

53 Zie bijv. D. CUYPERS, 'Beginselen van behoorlijk bestuur in personeelsmateries: zowel voor ambtenaren als voor overheidscontractanten' in R. JANVIER en A. DE BECKER (eds.), De rechtspositie van het overheidspersoneel in beweging, Brugge, die Keure, 2014, 24 ev. In dezelfde zin wordt aanvaard dat via de open norm van de goede trouw grondrechten kunnen doorwerken in horizontale, privaatrechtelijke relaties (onrechtstreekse horizontale werking). Zie S. STIJNS en S. JANSEN, 'De basisbeginselen van het contractenrecht: kroniek van de recentste evoluties', TBBR 20I3, afl. I, I2-I3. 
in welke mate, het goedetrouwcriterium uit artikel II34 BW dienst kan doen als spreekwoordelijke 'hefboom' voor de toepassing van beginselen van behoorlijk bestuur bij de uitvoering van overheidsovereenkomsten.

\subsection{Draagwijdte en toepassingsgebied van de beginselen van openbare dienst}

27. In tegenstelling tot de beginselen van behoorlijk bestuur - die de beoordelingsvrijheid van de overheid beperken - kennen de wetten of beginselen van de openbare dienst het bestuur juist specifieke ('exorbitante') prerogatieven toe ${ }^{54}$ en vergroten ze dus de (beoordelings)vrijheid van de overheid veeleer dan die te beperken. ${ }^{55}$ Deze beginselen zijn van toepassing op de instanties die belast zijn met het uitoefenen van een openbare dienst, hetgeen in rechtsleer en rechtspraak meestal in verband wordt gebracht met het uitvoeren van 'taken van algemeen belang'. ${ }^{56}$ Het begrip openbare dienst moet hier in functionele zin worden begrepen, in die zin dat ook privaatrechtelijke rechtspersonen een openbare dienst kunnen behartigen. ${ }^{57}$ Het vindt zijn grondslag in het Franse administratieve recht, ${ }^{58}$ en wordt daar - in tegenstelling tot bij ons - gebruikt als algemeen criterium voor het bepalen van de bevoegdheid van de gewone en de administratieve rechter. ${ }^{59}$ De nationale begripsinvulling moet overigens steeds vaker plaats maken voor de Europeesrechtelijke begrippen 'diensten van algemeen belang (DAB)' en 'diensten van algemeen economisch belang (DAEB)', waarmee enige verwantschap bestaat zonder dat zij elkaar echter volledig overlappen. ${ }^{60}$

54 Zie daarover D. D'HOOGHE en P. DE KEYSER, 'Het continuïteitsbeginsel en het veranderlijkheidsbeginsel' in I. OPDEBEEK en M. VAN DAMME (eds.), Beginselen van behoorlijk bestuur, Brugge, Die Keure, 2006, 363-396 en E. VAN HOOYDONK, 'Het artikel I30 van de Grondwet als algemene grondslag van het bestendigingsbeginsel in het administratief recht', ТВР I992, 75-88.

55 Uit deze beginselen worden enkel afwijkingen afgeleid ten voordele van de overheid, Zo put de gebruiker van een openbare dienst uit het continuïteitsbeginsel in beginsel geen subjectief recht op het behoud of de permanente werking van die dienst (Cass. I2 februari 2004, C.01.0248.N, concl. G. DUBRULLE). Zie ook hierover: D. DEOM, Le statut juridique des entreprises publiques, Brussel, StoryScientia, I990, 423-324 en L.-P. SUETENS en S. SWARTENBROUX-VANDERHAEGEN, 'Evolutie van het begrip 'openbare dienst" in I.C.V. STAATSRECHT (ed.), De nieuwe vormen van overheidstussenkomst in de onderneming, Brussel, Bruylant, I988, nr. I5.

56 D. D'HOOGHE en P. DE KEYSER, 'Het continuïteitsbeginsel en het veranderlijkheidsbeginsel' in I. OPDEBEEK en M. VAN DAMME (eds.), Beginselen van behoorlijk bestuur, Brugge, Die Keure, 2006, 364.

57 Zie hierover S. LIERMAN, Besturen zonder grenzen. Over grijze zones en blinde vlekken, Acta Falconis, VIII, Antwerpen, Cambridgde, Intersentia, 2015, 31, e.v. In zijn functionele betekenis verwijst de openbare dienst naar de taakbehartiging van algemeen belang, ongeacht de publieke of private rechtsvorm. De openbare dienst in organieke zin slaat daarentegen op de (klassieke) organismen van publiekrecht.

58 L.-P. SUETENS en S. SWARTENBROUX-VANDERHAEGEN, 'Evolutie van het begrip 'openbare dienst'، in I.C.V. STAATSRECHT (ed.), De nieuwe vormen van overheidstussenkomst in de onderneming, Brussel, Bruylant, I988, 279-302; J. DE STAERCKE, Algemene beginselen van behoorlijk bestuur en behoorlijk burgerschap: beginselen van de openbare dienst, Brugge, Vanden Broele, 2002, 7I e.v. en E. VAN HOOYDONK, 'Het artikel Izo van de Grondwet als algemene grondslag van het bestendigingsbeginsel in het administratief recht', TBP I992, 75-88.

59 J. RIVERO, Droit administratif, Parijs, Dalloz, I983, nrs. I57-I62.

6o Omwille van deze Europese doorwerking acht M. Amilhat de Franse theorie van het administratief contract ten dode opgeschreven en bepleit hij een op de Europese leest geschoeide theorie van het publiek contract (M. AMILHAT, La notion de contrat administratif. L'influence du droit de l'Union 
28. Klassiek worden drie beginselen van openbare dienst onderscheiden: het continuïteitsbeginsel, het veranderlijkheidsbeginsel en het beginsel van de benuttigingsgelijkheid. Het continuïteitsbeginsel houdt in dat diensten die beantwoorden aan een behoefte van algemeen belang moeten blijven bestaan en permanent moeten kunnen functioneren. ${ }^{6}{ }^{\mathrm{r}}$ Aan 'openbare diensten' moet dus een zekere continuïteit worden gegarandeerd. Het beginsel wordt afgeleid uit het vereiste van de 'permanentie van de staatsfunctie'. ${ }^{62}$ Volgens het Hof van Cassatie vereist 'de ononderbroken voortzetting van de werking van de staat, hoofdzakelijke voorwaarde tot zijn bestaan, [...] dat de staat zich nooit in de juridische onmogelijkheid zou bevinden om zijn opdracht te vervullen'. ${ }_{3}$

Een belangrijk, maar deels achterhaald, gevolg van het continuïteitsbeginsel is het principe van de uitvoeringsimmuniteit van de overheid. ${ }^{64}$ Voor het beslag op overheidsgoederen (d.i. een vorm van 'onrechtstreekse executie' ${ }^{65}$ ) kreeg het continuiteitsbeginsel uitdrukkelijk vorm in artikel I4I2bis van het Gerechtelijk Wetboek. ${ }^{66}$ Als afwijking van het principe dat overheidsgoederen niet vatbaar zijn voor beslag, kunnen deze goederen krachtens deze bepaling het voorwerp van beslag uitmaken wanneer deze (I) door de betrokken overheid op een daartoe bestemde lijst zijn ingeschreven, dan wel (2) 'kennelijk niet nuttig' zijn voor de uitoefening van de taak van deze overheid of voor de continuïteit van de openbare dienst, wanneer er geen dergelijke lijst werd opgemaakt of indien de goederen op de lijst niet volstaan tot voldoening van de schuldeisers. Maatregelen van rechtstreekse executie, dit zijn gedwongen uitvoeringsmaatregelen waardoor de aanspraken van de schuldenaar meteen worden verwezenlijkt, worden beperkt door het (ongeschreven) continuïteitsbeginsel. ${ }^{67}$ Volgens dat beginsel is het in principe niet mogelijk om de

européenne, Brussel, Bruylant, 20I4, 86). Zie ook het pleidooi van S. VAN GARSSE om de traditionele omschrijving van concessie te herzien onder invloed van het EU-recht (i.h.b. het aanbestedingsrecht): S. VAN GARSSE, De concessie in het raam van publiek-private samenwerking: een analyse van het openbaar en het privaat domein, van de domeinconcessies, de concessies van openbare werken, de concessies van diensten en hun aanbesteding, Brugge, die Keure, 2007, 615.

6I A. MAST, J. DUJARDIN, M. VAN DAMME en J. VANDE LANOTTE, Overzicht van het Belgisch administratief recht, Mechelen, Kluwer, 20I4, I05 e.v.

62 J. GIJSSELS, 'Het stakingsrecht in de overheidsdiensten en het kontinuïteitsbeginsel' in M. VAN HOECKE (ed.), Algemene rechtsbeginselen, Antwerpen, Kluwer, I99I, 300.

63 Cass. io januari I950, Arr. Cass. I950, 28 r.

64 Ook de wettelijke regel dat intergemeentelijke samenwerkingsverbanden (o.g.v. artikel II Decreet 6 juli 200I houdende de intergemeentelijke samenwerking, BS 3I oktober 200I) en economische overheidsbedrijven (o.g.v. artikel 8 Wet 2I maart I99I betreffende de hervorming van sommige economische overheidsbedrijven, BS 27 maart I99I) principieel niet failliet kunnen worden verklaard, wordt traditioneel verantwoord aan de hand van het continuïteitsbeginsel. Privaatrechtelijke ondernemingen zouden zich echter, zelfs wanneer zij een taak van algemeen belang uitoefenen, niet op het continuïteitsbeginsel kunnen beroepen om aan de toepassing van de faillissementsregeling te ontkomen ( $\mathrm{R}$. ERGEC en H. DELWAIDE, 'Les entreprises publiques peuvens-elles être déclarées en faillite?', JT I995, 7I3-7I7; B. PEETERS, De continuïteit van het overheidsondernemen, Antwerpen, Maklu, I989, 620).

65 Maatregelen van onrechtstreekse uitvoering zijn maatregelen die bijv. rechtstreeks betrekking hebben op het vermogen van de schuldenaar als drukkingsmiddel om zijn verplichtingen na te komen. Een ander voorbeeld is de dwangsom.

66 Zie hierover in detail E. DIRIX, 'art. I4I2bis Ger.W.' in X. (eds.), Gerechtelijk recht. Artikelsgewijze commentaar met overzicht van rechtspraak en rechtsleer, Mechelen, Kluwer, losbl.

67 D. D'HOOGHE en P. DE KEYSER, 'Het continuïteitsbeginsel en het veranderlijkheidsbeginsel' in I. OPDEBEEK en M. VAN DAMME (eds.), Beginselen van behoorlijk bestuur, Brugge, Die Keure, 2006, 369-370. 
uitvoering van verbintenissen effectief af te dwingen tegenover de overheid, indien deze niet vrijwillig tot de uitvoering overgaat. ${ }^{68} \mathrm{Zo}$ acht het Hof van Cassatie een rechterlijke machtiging om het herstel in natura bij verzuim van de overheid zelf te laten uitvoeren (op kosten van de overheid) niet mogelijk indien daardoor de continuïteit van de openbare dienst in het gedrang komt. ${ }^{69}$

Het veranderlijkheidsbeginsel houdt in dat de overheid haar beleid steeds moet kunnen aanpassen aan de wisselende eisen van het algemeen belang. ${ }^{70}$ Hoewel semantisch enigszins tegengesteld aan het continuïteitsbeginsel, is het er in wezen een aspect van. Continuïteit vereist immers dat het bestuur zich te allen tijde kan aanpassen aan wisselende omstandigheden.

Het beginsel van de benuttigingsgelijkheid is ten slotte eigenlijk niet meer dan een concretisering van het grondwettelijk gelijkheidsbeginsel. Het houdt in dat alle burgers ten aanzien van het gebruik van de openbare dienst gelijk moeten worden behandeld..$^{71}$

29. Hoewel de rechtsleer vaak het stilzwijgen bewaart over het toepassingsgebied van de beginselen van de openbare dienst, is ook hier de essentiële vraag in welke mate de behartiging van een openbare dienst een uitzonderingspositie verantwoordt voor de personen die daarmee zijn belast. ${ }^{72}$ De rechtspraak over het toepassingsgebied van de beginselen van de openbare dienst is zeldzaam en heeft meestal betrekking op specifieke rechtsverhoudingen zoals bij overheidsopdrachten ${ }^{73}$ of concessies van openbare diensten, ${ }^{74}$ zodat voorzichtigheid geboden is bij een veralgemening naar andere administratieve overheidscontracten. Doorgaans gaat de

68 Zie daarover bijv. B. PEETERS, 'Dwanguitvoering op overheidsgoederen. Een commentaar op art. I4I2bis Ger.W.', TBP I995, 67-75 en A.-M. STRANART en P. GOFFAUX, 'L'immunité d'exécution des personnes publiques et l'article I4I2bis du Code Judiciaire', JT I995, 437-447.

69 Cass. 26 april I980, Arr. Cass. I970-I980, I365. Anders: Cass. 24 april I998, Arr. Cass. I998, 210, RW 2000-200I, II95, noot S. BRIJS; zie ook: E. DIRIX, 'art. I4I2bis Ger.W.' in X. (eds.), Gerechtelijk recht. Artikelsgewijze commentaar met overzicht van rechtspraak en rechtsleer, Mechelen, Kluwer, losbl; D. D’HOOGHE en P. DE KEYSER, 'Het continuïteitsbeginsel en het veranderlijkheidsbeginsel' in I. OPDEBEEK en M. VAN DAMME (eds.), Beginselen van behoorlijk bestuur, Brugge, Die Keure, 2006, 370.

70 D. D'HOOGHE, 'Bestuurlijke vrijheid geklemd tussen de beginselen inzake rechtszekerheid, wettigheid en veranderlijkheid', RW I993-94, IIO2.

$7 \mathrm{I} \quad \mathrm{RvS} 27$ september I988, nr. 364.488.

72 D. D'HOOGHE en P. DE KEYSER, 'Het continuïteitsbeginsel en het veranderlijkheidsbeginsel' in I. OPDEBEEK en M. VAN DAMME (eds.), Beginselen van behoorlijk bestuur, Brugge, die Keure, 2006, 364 .

73 Zie bijv. M.-A. FLAMME, Traité théorique et pratique des marchés publics, Brussel, Bruylant, 1969, I47, wiens verwijzingen naar rechtspraak hoofdzakelijk, zoniet uitsluitend, betrekking hebben op overeenkomsten voor werken, leveringen en diensten voor rekening van de overheid; W. VAN GERVEN, Beleidsovereenkomsten, Academiae analecta, Brussel, Paleis der Academiën, 1984, 44; W. VAN GERVEN, De overheid in het verbintenissenrecht: hoe blauw is het bloed van de prins?, Antwerpen, Kluwer, I984, 68-69.

74 Zie bijv. de standaardarresten Cass. I4 februari I935, Pas. I935, I, I55 en Cass. 24 oktober I958, Pas. I959, I, 202, die beide betrekking hebben op concessieovereenkomsten en waaruit meestal wordt afgeleid dat de overheid de mogelijkheid heeft om contracten in het algemeen belang eenzijdig te beëindigen (het veranderlijkheidsbeginsel). Zie ook Cass. 3i mei I978, Arr. Cass. I978, II59 e.v. 
rechtspraak voorbij aan de preliminaire vraag naar het toepassingsgebied van de beginselen om onmiddellijk de draagwijdte en de betekenis van deze beginselen in het concrete geval te onderzoeken.

De rechtspraak lijkt aldus eerder pragmatisch en ad hoc deze beginselen toe te passen bij de uitvoering van administratieve overheidscontracten. Deze in concreto-benadering wekt in wezen weinig onrust op en kan zelfs op goedkeuring rekenen bij een groot deel van de rechtsleer die een meer abstracte aanpak moeilijk of onmogelijk acht. ${ }^{75}$ Wel betwist is of de toepassing van deze beginselen daadwerkelijk betekent dat de overheid in een contractuele verhouding haar bijzondere prerogatieven behoudt en m.a.w. in het algemeen belang beschikt over een absoluut wijzigingsrecht. Een deel van de rechtsleer verzet zich tegen deze publiekrechtelijke correctie op het gemeen contractenrecht en betoogt dat het veranderlijkheidsbeginsel in een contractuele verhouding enkel die rol kan spelen die er wettelijk of contractueel aan wordt gegeven. ${ }^{76}$ De verklaring voor de toepassing in de rechtspraak van deze beginselen bij de concessies van openbare dienst wordt dan gevonden in het feit dat de rechtsverhouding in dat geval gedeeltelijk reglementair van aard is. ${ }^{77}$ De analyse in het volgende hoofdstuk maakt echter duidelijk dat deze kwalificatie geen exacte wetenschap is. De verplaatsing van de discussie naar het onderscheid reglementcontract mag niet verhullen dat het ook hier gaat om dezelfde complexe afweging tussen algemene en private belangen, alsook om de verhouding tussen privaat- en publiekrecht.

De tendens lijkt in elk geval om de beginselen van de openbare dienst niet te beperken tot publiekrechtelijke rechtspersonen die taken van algemeen belang vervullen (organieke benadering), maar deze ook uit te breiden naar privaatrechtelijke personen die een taak van algemeen belang vervullen (functionele benadering).$^{78}$ Het onderscheid

75 Zie reeds W. VAN GERVEN, Beleidsovereenkomsten, Academiae analecta, Brussel, Paleis der Academiën, I984, 44; D. D’HOOGHE en P. DE KEYSER, 'Het continuïteitsbeginsel en het veranderlijkheidsbeginsel' in I. OPDEBEEK en M. VAN DAMME (eds.), Beginselen van behoorlijk bestuur, Brugge, Die Keure, 2006, 394; Contra M.-A. FLAMME, Traité théorique et pratique des marchés publics, Brussel, Bruylant, I969, I47, volgens wie de beginselen van de openbare dienst gelden voor alle administratieve contracten.

76 D. D'HOOGHE, 'Overeenkomsten met de overheid' in M. STORME, Y. MERCHIERS en J. HERBOTS (eds.), De overeenkomst vandaag en morgen, Antwerpen, Kluwer, I990, I55-I6o. D'HOOGHE en P. DE KEYSER, 'Het continuïteitsbeginsel en het veranderlijkheidsbeginsel' in I. OPDEBEEK en M. VAN DAMME (eds.), Beginselen van behoorlijk bestuur, Brugge, Die Keure, 2006, 395. Zie ook voor een kritische benadering: E. VAN DE VELDE, 'Afspraken' met de fiscus: de grenzen, juridische kwalificatie en rechtgevolgen, Gent, Larcier, 2009, 384; F. VANDENDRIESSCHE, Publieke en private rechtspersonen: naar een graduele, meerduidige en evolutieve benadering van het onderscheid in de wetgeving en de rechtspraak, Brugge, die Keure, 2004, II3; B. GORS, 'Le principe de mutabilité' in X. (eds.), Le service public 2. Les 'lois' du service public, Brussel, la Charte, 2009, (I05) I47.

77 D. D'HOOGHE, 'Overeenkomsten met de overheid' in M. STORME, Y. MERCHIERS en J. HERBOTS (eds.), De overeenkomst vandaag en morgen, Antwerpen, Kluwer, I990, I58-I59; zie echter de kritiek op deze gemengde kwalificatie bij: S. VAN GARSSE, De concessie in het raam van publiek-private samenwerking: een analyse van het openbaar en het privaat domein, van de domeinconcessies, de concessies van openbare werken, de concessies van diensten en hun aanbesteding, Brugge, die Keure, 2007, 453 e.v.

78 D. D'HOOGHE en P. DE KEYSER, 'Het continuïteitsbeginsel en het veranderlijkheidsbeginsel' in I. OPDEBEEK en M. VAN DAMME (eds.), Beginselen van behoorlijk bestuur, Brugge, Die Keure, 2006, 395. 
tussen de private en de publieke rechtsvorm is overigens zelf niet loepzuiver. De verzelfstandiging van het overheidsoptreden leidt tot een waaier aan rechtspersonen waarvan de ene al meer dan de andere afwijkt van het gemeen vennootschapsrecht. ${ }^{79}$ De definitie van het toepassingsgebied aan de hand van een functioneel criterium (d.i. de behartiging van een taak van algemeen belang), waarbij de organisatievorm op zich geen rol speelt, sluit bovendien goed aan bij het Europese recht. ${ }^{80}$ Dit laatste stelt bovenal de materiële rechtsverhouding centraal en besteedt doorgaans weinig aandacht aan de privaat- of publiekrechtelijke kwalificatie van de betrokken instelling. Naarmate het EU-recht overigens zelf meer waarborgen bevat waaraan een kwalitatieve en minimumdienstverlening moet beantwoorden, boeten de ongeschreven beginselen van openbare dienst aan belang in.

\section{Contract of reglement: het kompas is zoek}

\section{I Reglementaire kwalificatie als publiekrechtelijke correctie}

30. In het vorige hoofdstuk werd toegelicht dat het Belgische recht het Franse leerstuk van het administratief contract niet kent. Volgens dit leerstuk worden bepaalde overheidscontracten onderworpen aan een van het gemeen recht afwijkend en uitsluitend door de bestuursrechter toegepast rechtsregime. In tegenstelling tot Nederland kent België evenmin een algemene wet bestuursrecht, die een gemeenschappelijke set rechtsregels bevat voor overheidsoptreden. Hoewel het overheidscontractenrecht aldus in principe wordt beheerst door het privaatrecht, wordt dit uitgangspunt niet tot haar uiterste consequenties doorgetrokken. Wetgeving en rechtspraak hebben tal van afwijkingen en correcties ontwikkeld om overeenkomsten met de overheid te onderwerpen aan van het gemeen (privaat)recht afwijkende regels. Deze afwijkingen worden gerechtvaardigd vanuit de bekommernis om de overheid als hoeder van het algemeen belang bijzondere prerogatieven toe te kennen en een evenwicht te realiseren tussen dat algemeen belang en private belangen.

3I. Dit bijzondere statuut houdt doorgaans in dat de rechter een rechtsverhouding minstens gedeeltelijk kwalificeert als een reglementaire en dus publiekrechtelijke verhouding. Deze kwalificatie en in het bijzonder het onderscheid met een contractuele rechtsverhouding blijft in rechtspraak en rechtsleer aanleiding geven tot discussies. Dit wordt treffend geïllustreerd door de kwalificatie van clausules in de beheerscontracten die de overheid afsluit met overheidsondernemingen en waarvan het statuut veelal niet wettelijk is bepaald ${ }^{8 \mathrm{r}}$ (zie nr. 60). Ook over de aard van

79 Zie hierover meer uitgebreid: S. LIERMAN, Besturen zonder grenzen. Over grijze zones en blinde vlekken, Acta Falconis, VIII, Antwerpen, Cambridgde, Intersentia, 20I5, 32 e.v. Zie hierover in Nederland: N. JAK, Semipublieke instellingen. De juridische positie van instellingen op het snijulak van overheid en samenleving, Den Haag, Boom Juridische uitgevers, 20I4, 45Ip.

80 D. D'HOOGHE en P. DE KEYSER, 'Het continuïteitsbeginsel en het veranderlijkheidsbeginsel' in I. OPDEBEEK en M. VAN DAMME (eds.), Beginselen van behoorlijk bestuur, Brugge, Die Keure, 2006, 395.

8I Een uitdrukkelijke kwalificatie (als contractuele rechtsverhouding) is wel voorhanden in artikel 3, \$5, van de wet van 2I maart I99I betreffende de hervorming van sommige economische overheidsbedrijven. 
de rechtsverhouding tussen openbare nutsbedrijven en hun afnemers bijvoorbeeld, bestaat een niet aflatende discussie. De rechtsleer blijft verdeeld over de kwalificatie van deze rechtsverhouding, hoewel minstens de hogere rechtspraak duidelijk een principieel standpunt inneemt en de rechtsverhouding als reglementair beschouwt. ${ }^{82}$ Deze onenigheid heeft veel, zo niet alles, te maken met de onduidelijkheid over de criteria die bepalend zijn voor deze kwalificatie. Alvorens deze criteria te bespreken, staan we stil bij het belang van deze kwalificatie.

\subsection{Belang van het onderscheid}

32. De rechtsgevolgen van de kwalificatie als een reglementaire of contractuele rechtsverhouding kunnen ten eerste worden gesitueerd op het vlak van: (I) de rechtsbescherming en (2) het toepasselijke recht. ${ }^{8}$ Deze verschilpunten moeten echter worden genuanceerd o.m. omwille van de theorie van de acte détachable en het feit dat zowel de gewone rechter als de Raad van State dikwijls dezelfde instrumenten aanwenden (zij het steeds met een andere finaliteit). Het onderscheid heeft daarnaast gevolgen voor (3) de toepassing van het aansprakelijkheidsrecht, en (4) de vereisten van bekendmaking en de tegenstelbaarheid t.a.v. derden. Zeker het verschil wat betreft de tegenstelbaarheid is fundamenteel (zie daarover ook verder in hoofdstuk V). Het onzekere toepassingsgebied van (5) de beginselen van behoorlijk bestuur en (6) de wetten van de openbare dienst in een contractuele overheidsverhouding kwam ten slotte reeds aan bod in het vorige hoofdstuk.

\section{a. Rechtsbescherming}

33. De grondwettelijke rechtsmachtverdeling tekent zich in België grotendeels af tegen het onderscheid tussen het subjectieve en het objectieve beroep. Het objectieve beroep tot nietigverklaring voor de bestuursrechter is gericht op het herstel van de wettigheid die in het gedrang is gebracht door een bestuurshandeling van de overheid. De kwalificatie als reglement laat dus eenieder die een belang aantoont

82 RvS 3I maart I950, nr. 310, Buttgen; RvS 27 september I988, nr. 30.864, DCCR I989, 62, noot P. DE VROEDE; DAOR 1989, I07, noot D. PHILIPPE; Cass. 4 december 2000, RW 2002-03, p. 1578, noot A. VAN OEVELEN; Cass. 8 maart 2012, RW 2013-2014, noot I. CLAEYS; zie hierover in detail K.-J. VANDORMAEL, 'De rechtsverhouding tussen openbare diensten en gebruikers: van reglementaire of contractuele aard?' (noot bij Rb. Limburg Ig december 2014), Limb. Rechtsl. 2015, I86; I. CLAEYS, 'Normenhiërarchie en afwijkingen van (aansprakelijkheids)wetgeving in reglementaire verhoudingen' (noot onder Cass. 8 maart 2012), RW 2013-I4, I661-I662. Zie ook (ex multis): RvS 27 september 1988, nr. 30.876; Cass. 4 december 2000, RW 2002-2003, 1578-1583, noot A. VAN OEVELEN; recenter: Cass. 8 maart 2012, RW 2013-20I4, I660-I665, noot I. CLAEYS (rechtsverhouding is reglementair). Contra, zie vooral de (vroegere) rechtspraak van burgerrechtelijke rechtscolleges, bijv. Gent, 4 oktober 2007, TGR 2008, I05-IO6 (impliciet contractueel); Gent, 3I mei 2002, RW 2002-2003, I589; Antwerpen, 23 maart 1998, RW I998-I999, 223; Rb. Kortrijk, 2I april I997, Iuvis, 2000, I066, met noot; Kh. Hasselt I4 mei 2009, Limb. Rechtsl. 20II, I80-I83 (impliciet contractueel); Kh. Hasselt I8 november 2009, Limb. Rechtsl. 20II, I84-I87 (prijsbeslissing leverancier is partijbeslissing); Vred. Brussel I8 januari I99I, T. Vred. I99I, 336; B. PEETERS, 'De verhouding tussen openbare diensten en hun gebruikers: een contractuele of reglementaire relatie?', RW I990-I99I, I37-I48 (rechtsverhouding is contractueel).

83 Voor een gedetailleerd overzicht, zie K.-J. VANDORMAEL, 'De rechtsverhouding tussen openbare diensten en gebruikers: van reglementaire of contractuele aard?' (noot bij Rb. Limburg Ig december 2014), Limb. Rechtsl. 2015, 194 . 
toe om hiertegen een beroep in te stellen bij de bestuursrechter. Een vernietiging leidt ertoe dat de onwettige bepaling 'erga omnes' en met terugwerkende kracht uit het rechtsverkeer verdwijnt. De beslechting van geschillen over subjectieve burgerlijke rechten, met inbegrip dus van de rechten en de verplichtingen van contractspartijen, behoort daarentegen bij uitsluiting toe aan de gewone rechter. Deze doet uitsluitend uitspraak in de verhouding tussen de procespartijen en de beslissing geldt niet met terugwerkende kracht.

34. Dit onderscheid in rechtsbescherming moet echter worden genuanceerd. Vooreerst leidt de theorie van de 'acte détachable' of de afsplitsbare rechtshandeling ertoe dat ook de Raad van State in een contractuele context een vernietigingsbevoegdheid heeft. Hoewel het contract zelf niet door de administratieve rechter kan worden beoordeeld, zijn de eenzijdige rechtshandelingen die eraan voorafgaan of erop volgen wél voor vernietiging vatbaar (als 'afsplitsbare rechtshandelingen' van het contract). Zo is de beslissing van de overheid tot het sluiten van een contract aanvechtbaar bij de Raad van State.

Omgekeerd is de burgerlijke rechter bevoegd om kennis te nemen van alle betwistingen met betrekking tot subjectieve rechten, ongeacht of het nu een reglementaire of contractuele rechtsverhouding betreft. Ook in een reglementaire rechtsverhouding kan de burgerlijke rechter met andere woorden worden gevat, namelijk om uitspraak te doen over subjectieve rechten. Dit is het geval telkens wanneer het geschil betrekking heeft op de uitvoering van het reglement. ${ }^{8}$ Zowel de Raad van State als de gewone rechter kunnen dus kennis nemen van vorderingen die voortspruiten uit een reglementaire rechtsverhouding (zij het telkens met een andere finaliteit).

35. Een ander onderscheid houdt verband met de toepassing van artikel I59 van de Grondwet. Deze bepaling verplicht de (administratieve én gewone) rechter om bestuurshandelingen (dit zijn: besluiten en verordeningen) buiten toepassing te laten wanneer zij niet overeenstemmen met hogere rechtsnormen (de zgn. exceptie van onwettigheid). ${ }^{85}$ Deze exceptie van onwettigheid kan bijgevolg enkel worden toegepast binnen reglementaire rechtsverhoudingen. ${ }^{86}$ Binnen het kader van contractuele rechtsverhoudingen is artikel $159 \mathrm{Gw}$. enkel relevant als er sprake is van afsplitsbare rechtshandelingen (actes détachables).

Volgens sommigen is het onderscheid tussen een contractuele en een reglementaire rechtsverhouding ten slotte nog van belang voor de toepassing van het adagium

84 F. VANDENDRIESSCHE, W. GELDHOF en A. CARTON, 'De aard van de rechtsverhoudingen in nutssectoren: reglementair of contractueel?' in I. CLAEYS, R. STEENNOT en M. TISON (eds.), Economisch recht: ondernemingen, concurrenten en consumenten, Mechelen, Kluwer, 20II, 2II; de auteurs wijzen erop dat de meeste betwistingen tussen nutsbedrijven en hun gebruikers juist de toepassing van de reglementen betreffen.

85 De facto komt een buitentoepassingsverklaring van een individuele bestuurshandeling overigens op hetzelfde neer als een erga omnes vernietiging door de Raad van State. Zie C. BERX, Rechtsbescherming van de burger tegen de overheid, Antwerpen, Intersentia, 200I, I57-I58.

86 Zie daarover J. THEUNIS, De exceptie van onwettigheid, Brugge, Die Keure, 201I, 233 e.v. 
patere legem quam ipse fecisti. ${ }^{87}$ Dit algemeen rechtsbeginsel houdt in dat een overheid bij individuele beslissingen niet mag afwijken van de algemene regeling ('reglement') die zij zelf heeft uitgevaardigd. Een dergelijk reglement kan enkel door een ander besluit met algemene draagwijdte worden gewijzigd. ${ }^{88}$ Deze regel zou geen toepassing vinden binnen contractuele rechtsverhoudingen. Hiermee kan echter niet zonder meer worden ingestemd. Aangezien het adagium wordt afgeleid uit het wettigheidsbeginsel, moet de overheid ook bij haar contractuele optreden haar eigen reglementen indachtig zijn. Deze conclusie dringt zich des te meer op nu het adagium tevens in verband wordt gebracht met het rechtszekerheids- en het gelijkheidsbeginsel, in die zin dat gelijke situaties een gelijke behandeling behoeven. ${ }^{89}$ De ruimere contractuele bewegingsruimte van de overheid is veelal echter het gevolg van het niet van toepassing zijn van het reglement op de niet vergelijkbare situatie of categorie. Zo geldt het ambtenarenstatuut in principe enkel voor de statutaire ambtenaren, zodat de overheid er niet door is gebonden wanneer ze personeel contractueel aanwerft.

\section{b. Toepasselijke recht}

36. In een contractuele relatie geldt het gemene verbintenissenrecht als aanvullend recht wanneer partijen hierover niets hebben afgesproken. In de meerderheid van de rechtsleer kan men lezen dat in reglementaire rechtsverhoudingen de regels en beginselen uit het burgerlijk recht niet toepasselijk zijn..$^{\circ}$ Deze opvatting vindt steun in cassatierechtspraak waarin werd geoordeeld dat in een reglementaire rechtsverhouding artikel I23I, SI eerste lid BW (dat de mogelijkheid voor de rechter tot matiging van een strafbeding omvat) niet kan worden toegepast, juist omdat het niet gaat om een contractuele, maar om een reglementaire rechtsverhouding. ${ }^{. \mathrm{I}}$ Het Hof van Cassatie lijkt dus een suppletieve toepassing van het verbintenissenrecht op reglementaire relaties te verwerpen. Het belangrijkste verschil is wellicht dat het reglement in het algemeen belang eenzijdig kan worden vastgesteld en gewijzigd, terwijl in een contractuele verhouding de wederzijdse instemming van de partijen vereist is. ${ }^{92}$

37. Opnieuw moet dit onderscheid echter worden genuanceerd. Zo wordt soms aangenomen dat het verbintenissenrecht naar analogie van toepassing kan zijn in

87 F. COUSY, 'De Vlaamse distibutienetbeheerders voor elektriciteit en de bescherming van de consument', DCCR 2007, I70. Zie ook reeds B. PEETERS, 'De verhouding tussen openbare diensten en hun gebruikers: een contractuele of reglementaire relatie?', RW I990-I99I, I39.

88 A. MAST, J. DUJARDIN, M. VAN DAMME en J. VANDE LANOTTE, Overzicht van het Belgisch administratief recht, Mechelen, Kluwer, 20I4, I9-20.

89 A. MAST, J. DUJARDIN, M. VAN DAMME en J. VANDE LANOTTE, Overzicht van het Belgisch administratief recht, Mechelen, Kluwer, 20I4, IO40.

90 Zie bijv. F. VANDENDRIESSCHE, W. GELDHOF en A. CARTON, 'De aard van de rechtsverhoudingen in nutssectoren: reglementair of contractueel?' in I. CLAEYS, R. STEENNOT en M. TISON (eds.), Economisch recht: ondernemingen, concurrenten en consumenten, Mechelen, Kluwer, 20II, 2I3 en F. COUSY, 'De Vlaamse distributienetbeheerders voor elektriciteit en de bescherming van de consument', DCCR 2007, I69.

9 I Cass. 3 juni 2010, C.08.0581.N.

92 B. PEETERS, 'De verhouding tussen openbare diensten en hun gebruikers: een contractuele of reglementaire relatie?', RW I990-I991, I39. 
een reglementaire rechtsverhouding, althans voor zover dit niet onverenigbaar is met de (wets)voorschriften die deze verhouding beheersen. ${ }^{93}$

Hoewel vertrekkend vanuit een tegengesteld uitgangspunt, leek de Raad van State deze opvatting genegen waar hij stelde dat 'de bepalingen van het Burgerlijk Wetboek die de verzoekende partijen aanhalen, als zodanig uiteraard niet van toepassing zijn, daar ze alle voorkomen in de titels van het Burgerlijk Wetboek die contractenrecht bevatten; dat het wel niet a priori uitgesloten mag worden geacht dat die bepalingen of sommige ervan niets meer zijn dan de concretisering van het algemeen rechtsbeginsel dat de verzoekende partijen geschonden noemen; dat dit algemeen rechtsbeginsel eigenlijk het redelijkheidsbeginsel is, een beginsel dat het bestuur verbiedt tegen alle redelijkheid in te handelen, met name door in strijd met alle redelijkheid te doen wat volgens de verzoekende partijen het bestuur in de onderhavige zaak heeft gedaan, namelijk het krenken van de belangen van de elektriciteitsverbruikers; dat dit gemis van de meest elementaire redelijkheid ook hierin kan bestaan dat in een materie die, was ze geen voorwerp van een openbare dienst, onder het contractenrecht zou vallen, zonder enige aanwijsbare reden regelingen worden vastgesteld die anders zijn dan die vervat in het contractenrecht' (eigen cursivering). ${ }^{94}$

Omgekeerd kunnen een aantal typisch publiekrechtelijke beginselen - zoals de beginselen van behoorlijk bestuur en de beginselen van de openbare dienst - rechtstreeks of onrechtstreeks - uitwerking hebben in een contractuele rechtsverhouding (zie verder in hoofdstuk 5). Bovendien komt steeds vaker publiekrechtelijke wetgeving tot stand - niet in het minst onder invloed van het EU-recht - die geldt ongeacht of het gaat om een contractuele of een reglementaire verhouding. Zo is de wetgeving op de consumentenbescherming (artikel VI.I -VI.I28 WER, vroeger WMPC $^{95}$ ) steeds van toepassing in de relatie tussen verkopers en consumenten en heeft deze kwalificatie niet het minste belang..$^{6}$

\section{c. Toepassing van het aansprakelijkheidsrecht}

38. Het contractuele en het buitencontractuele aansprakelijkheidsrecht gaan terug op een eigen rechtsgrondslag - respectievelijk artikel II 34 BW en artikel I382 BW -

93 In dezelfde zin B. PEETERS, 'De verhouding tussen openbare diensten en hun gebruikers: een contractuele of reglementaire relatie?', RW I990-I99I, I40; zie daarover ook: K.-J. VANDORMAEL, 'De rechtsverhouding tussen openbare diensten en gebruikers: van reglementaire of contractuele aard?' (noot bij Rb. Limburg I9 december 2014), Limb. Rechtsl. 2015, I98; en K.-J. VANDORMAEL, Het Grondwettelijk Hof: rechter of regelgever - Analyse van de draagwijdte van de rechtspraak van het Grondwettelijk Hof, Brussel, Larcier, 2015, 70 (72) e.v.

94 RvS 27 september I988, nr. 30.876, De Leener en Ballon, Consumentenrecht I989, 62-87, noot P. DE VROEDE; DAOR I989, I07, met noot D. PHILIPPE; JT I989, 7I6; T.Gem. I989, 200.

95 Wet marktpraktijken en consumentenbescherming (hierna: 'WMPC').

96 K.-J. VANDORMAEL, 'De rechtsverhouding tussen openbare diensten en gebruikers: van reglementaire of contractuele aard?' (noot bij Rb. Limburg I9 december 20I4), Limb. Rechtsl. 2015, I99. Dit is vaststaande rechtspraak, zie bijv. (impliciet) GwH 9 juli 2013, nr. IoI/2013; GwH 26 oktober 2005, DCCR 2006, 49, noot R. STEENNOT; Gent 20 december 20Io, onuitgeg. 
en volgen een enigszins verschillend rechtsregime. ${ }^{97}$ Het samenloopverbod verhindert in de regel dat contractspartijen zich op de regels van buitencontractuele aansprakelijkheid zouden kunnen beroepen..$^{98}$ Omgekeerd kunnen partijen in een reglementaire rechtsverhouding zich, bij afwezigheid van overeenkomst, vanzelfsprekend enkel beroepen op artikel $\mathrm{I}_{3} 82 \mathrm{BW}$.

Artikel II34 BW (contractuele aansprakelijkheid), noch artikel I382 e.v. BW (buitencontractuele aansprakelijkheid) zijn van openbare orde of van dwingend recht. Het Hof van Cassatie aanvaardt dan ook dat hier bij (overheids)overeenkomst van kan worden afgeweken (exoneratiebedingen - schadebedingen). ${ }^{99}$ Deze mogelijkheid tot andersluidende regeling bestaat in principe niet in het kader van een reglementaire verhouding. Artikel $159 \mathrm{Gw}$., dat een uitdrukking vormt van het legaliteitsbeginsel, is immers in algemene bewoordingen gesteld, zonder dat het een onderscheid maakt naargelang de aard van de wetten waarmee de daarin bedoelde besluiten en verordeningen moeten overeenstemmen. ${ }^{100}$ Behoudens andersluidende machtiging dringen deze wilsaanvullende bepalingen zich dus aan de overheid op, zonder dat deze hier eenzijdig kan van afwijken. ${ }^{\text {or }}$ Dikwijls zal dergelijke machtiging tot afwijking echter, minstens impliciet, wel degelijk voorhanden zijn. ${ }^{\text {102 }}$

97 Hoewel er in de rechtsleer op wordt gewezen dat er de laatste jaren sprake is van harmonisatie. Het gaat dan ook veeleer om technische verschilpunten (bijv. de verjaringsregeling). Zie B. WEYTS en T. VANSWEEVELT, Handboek buitencontractueel aansprakelijkheidsrecht, Antwerpen, Intersentia, 2009, 87. Zie ook P. WÉRY, 'Les rapports entre responsabilité aquilienne et responsabilité contractuelle' in X (eds.), Droit de la responsabilité, Louvain-la-Neuve, Anthemis, 2008, I2.

98 Volgens het Hof van Cassatie kan een contractant enkel nog buitencontractueel aansprakelijk worden gesteld indien (I) de ten laste gelegde fout een tekortkoming uitmaakt aan de algemene zorgvuldigheidsplicht; en (2) deze fout een andere dan aan de slechte uitvoering te wijten schade heeft veroorzaakt. Zie Cass. 29 september 2006, C.03.0502.N; Cass. 7 december 1973, Pas. I974, I, 376. In hoeverre naast de inbreuk op de algemene zorgvuldigheidsplicht ook nog sprake kan zijn van een tekortkoming aan het contract is betwist. Zie D. VERVOORT, 'De relevantie van het Tiercéarrest voor de rechtspraak: een slag in het water' (noot onder Brussel I7 september 2012), TBBR 20I5, afl. 5, 260 .

99 Cass. 26 oktober I877, Pas. I877, I, 406; Cass. I2 november I885, Pas. I885, I, 275 (contractuele aansprakelijkheid); Cass. 2I februari I907, Pas. I907, I, I35 (buitencontractuele aansprakelijkheid). Zie ook P. VAN OMMESLAGHE, Les obligations (vol. 2), Brussel, Bruylant, 2013 , I708.

IOo Cass. 8 maart 20I2, C.II.0568.N.

IOI A contrario Antwerpen 7 juni I999, RW 2000-or, 5 I en de noot hierbij van A. DE BOECK, 'De toetsing van de geldigheid van de in havenreglementen opgenomen bevrijdingsbedingen aan de beginselen van behoorlijk bestuur', RW 2000-02I, 54; Antwerpen 6 september I994, AJT-dossier 1995-96, I53.

I02 De rechtsleer stelt zich overigens soepel op bij de beoordeling van de aanwezigheid van een dergelijke impliciete machtiging. Voor het Gemeentelijk Havenbedrijf Antwerpen wordt het bijv. voldoende geacht dat het havenbedrijf gerechtigd is 'alle nodige verordeningen en reglementen' uit te vaardigen tot beheer en exploitatie van de haven (artikel I4 Wet I9 juni I 978 betreffende het beheer van het linkerscheldeoevergebied ter hoogte van Antwerpen en houdende maatregelen voor het beheer en de exploitatie van de haven van Antwerpen). I. CLAEYS en S. RYNWALT stellen zich daarbij de vraag of de bevoegdheid om eenzijdig de primaire verbintenissen te regelen niet a fortiori de bevoegdheid meebrengt om ook de secundaire verbintenissen tot schadevergoeding te moduleren. Zie I. CLAEYS en S. RYNWALT, 'Normenhiërarchie en afwijkingen van (aansprakelijkheids) wetgeving in reglementaire verhoudingen' (noot onder Cass. 8 maart 20I2), RW 2013-20I4, I66o. Over de impliciete grondslag in de elektriciteitssector, zie K.-J. VANDORMAEL, 'De rechtsverhouding tussen openbare diensten en gebruikers: van reglementaire of contractuele aard? (noot bij Rb. Limburg, I9 december 2014)', Limb. Rechtsl. 2015, 202. 


\section{d. Vereisten van bekendmaking en tegenstelbaarheid t.a.v. derden}

39. Een reglement heeft een algemene draagwijdte en is tegenstelbaar erga omnes. Dit impliceert o.m. dat elke belanghebbende zich in rechte op de inhoud van dit reglement kan beroepen en hier desgevallend ook rechten aan kan onttrekken. Zo kunnen gebruikers van de openbare dienst zich ten aanzien van een concessiehouder beroepen op de door de overheid vastgelegde tariefregeling (zie nr. 54). Daartegenover staat dat elke belanghebbende zich in het kader van een juridische procedure tegen de inhoud van het reglement kan verzetten. De reglementaire verhouding verschilt op dit punt fundamenteel van de contractuele verhouding waar relativiteit het uitgangspunt is (artikel $\mathrm{II}_{5} \mathrm{BW}$ ). ${ }^{\mathrm{I} 3}$ Uit een overeenkomst vloeien in beginsel enkel rechten en verplichtingen voort ten aanzien van de contractspartijen zelf (inter partes). Alle andere belanghebbenden kunnen zich, als derden, in principe dan ook niet in rechte beroepen op (noch verzetten tegen) ${ }^{\text {I04 }}$ de inhoud van het contract.

40. Een reglement wordt geacht gekend te zijn, en is dus tegenstelbaar, vanaf het ogenblik van publicatie. ${ }^{\text {I05 }}$ Effectieve kennisname of aanvaarding is hiervoor niet vereist. ${ }^{106}$ In het verleden oordeelde het Hof van Cassatie bijvoorbeeld dat gewijzigde algemene voorwaarden in de reglementaire verhouding tussen een openbare dienstverlener en zijn gebruikers onmiddellijk aan deze laatsten kunnen worden tegengeworpen, zonder dat nog aanvaarding moet worden bewezen. ${ }^{\text {I07 }}$ Ook hierin verschilt het reglement duidelijk van een overeenkomst. Zo wordt traditioneel aangenomen dat algemene voorwaarden in een overeenkomst slechts uitwerking vinden wanneer de tegenpartij van deze voorwaarden heeft kunnen kennisnemen, en deze ook effectief heeft aanvaard. ${ }^{108}$

\subsection{Gebrek aan duidelijke onderscheidingscriteria}

4I. Traditioneel wordt de reglementaire aard van de rechtsverhouding gerechtvaardigd op basis van vier argumenten: ${ }^{\text {109 }}$

I03 Zie daarover in detail K.-J. VANDORMAEL, 'De rechtsverhouding tussen openbare diensten en gebruikers: van reglementaire of contractuele aard? (noot bij Rb. Limburg I9 december 20I4)', Limb. Rechtsl. 2015, I99.

I04 Hier geldt het voorbehoud van de theorie van de actes détachables.

I05 Zie daarover bijv. T. GOETHALS, 'Factuurvoorwaarden' in G.L. BALLON en I. SAMOY (eds.), De factuur en aanverwante documenten, Brugge, Vanden Broele, 2008, 82-83.

ro6 Kennisname wordt onweerlegbaar vermoed. Zie P. QUERTAINMONT, Droit publique économique. Interventionnisme économique des pouvoirs publics, Waterloo, Kluwer, 2007, I4I.

I07 Cass. 4 december 2000, RW 2002-03, I578, noot A. VAN OEVELEN.

Io8 Zie daarover K.-J. VANDORMAEL en G.L. BALLON, 'Creatief met factuurvoorwaarden', in X. (eds.), Proactief ondernemingsrecht, Antwerpen, Intersentia, 20I3, 26 e.v. Zie daarnaast de zeer kritische rechtspraak met betrekking tot (niet op de contractsdocumenten) gepubliceerde algemene voorwaarden, bijv. Antwerpen I5 maart 2004, NjW 2005, 703 en RW 2004-05, I354; Brussel I2 september I997, TBBR I998, 352 en S. STIJNS en K. VANDERSCHOT, Contractuele clausules rond de (niet-)uitvoering en de beëindiging van contracten, Antwerpen, Intersentia, 2006, 6 en 28-29, met uitvoerige verwijzingen.

Io9 Zie daarover in detail K.-J. VANDORMAEL, 'De rechtsverhouding tussen openbare diensten en gebruikers: van reglementaire of contractuele aard? (noot bij Rb. Limburg I9 december 20I4)', Limb. Rechtsl. 20I5, te verschijnen. 


\section{a. Uitoefening van een openbare dienst}

42. Dit argument, dat overigens aansluit bij de gevestigde rechtspraak van de Raad van State ${ }^{\text {IIo }}$, werd door het Hof van Cassatie meermaals gebruikt om de verhouding tussen nutsbedrijven en gebruikers te kwalificeren als reglementair. ${ }^{\mathrm{II}}$ Het argument dat een rechtsverhouding reglementair moet zijn telkens wanneer er sprake is van een 'openbare dienst', is op zich echter niet overtuigend. Eerst en vooral is het nog maar de vraag wat een 'openbare dienst' precies is. Bij gebrek aan een wettelijke definitie wordt meestal teruggegrepen naar de vage notie 'taak van algemeen belang', maar ook dat begrip staat open voor interpretatie. ${ }^{\mathrm{II} 2}$ Daarenboven lijkt het begrip, o.a. ten gevolge van de privatiseringsgolf onder invloed van het Europese recht, steeds restrictiever te worden ingevuld. Bovenal verhindert het openbaredienstkarakter op zich niet dat er gebruik wordt gemaakt van contractuele technieken. De kwalificatie van een 'openbare dienst' verplicht dus zeker niet tot een reglementaire rechtsverhouding. ${ }^{113}$ Het openbaredienstkarakter brengt wel met zich mee dat, ook wanneer deze via de 'privaatrechtelijke weg' wordt uitgebaat, aan bepaalde (bijkomende) publiekrechtelijke regels en beginselen moet worden voldaan (zie hierover hoofdstuk 4).

Het is dus niet zo dat de kwalificatie van 'openbare dienst' impliceert dat de rechtsverhouding tussen dienstverlener en gebruikers reglementair moet zijn (al zal dat vaak wel het geval zijn).

\section{b. Grondwettelijk gelijkheidsbeginsel (artikelen Io en II Gw.)}

43. Het argument dat het grondwettelijk gelijkheidsbeginsel zich verzet tegen individuele afwijkingen, terwijl er bij toetredingscontracten in de regel wél individuele afwijkingen kunnen worden gemaakt, werd eertijds door de Raad van State aangewend om de contractuele benadering te verwerpen. ${ }^{\mathrm{II} 4}$ Ook dit argument mist overtuigingskracht: zoals in de rechtsleer herhaaldelijk betoogd, sluit het vereiste van de gelijke behandeling van de afnemers van een openbare dienst (het zgn. benuttigingsgelijkheidsbeginsel, zie nr. 28) geenszins een contractuele verhouding uit. ${ }^{\text {II }}$

IIo Zie reeds RvS 3I maart I950, nr. 3I0; RvS 27 september I988, nr. 30.876.

III Het Hof houdt het enigmatisch op 'gelet op het feit dat de elektriciteitsdistributeur een openbare dienst verleent, de voorwaarden voor de levering van elektriciteit van reglementaire aard zijn' (Cass. 4 december 2000, C.99.0095.F); zie ook Cass. 8 maart 20I2, C.II.0027.N, concl. A-G G. DUBRULLE.

II2 Het is in het kader van deze bijdrage niet de bedoeling om een allesomvattende definitie van het begrip 'openbare dienst' te formuleren. Voor een poging, zie K.-J. VANDORMAEL, 'De rechtsverhouding tussen openbare diensten en gebruikers: van reglementaire of contractuele aard? (noot bij Rb. Limburg I9 december 2014)', Limb. Rechtsl. 2015, I87.

II3 Zie daarover W. VAN GERVEN, De overheid in het verbintenissenrecht-Hoe blauw is het bloed van de prins?, Kluwer, Antwerpen, I984, (76) 89 .

II4 Zie RvS 27 september I988, nr. 30.876, overweging 2.3.I.

II5 Zie bijv. B. PEETERS, 'De verhouding tussen openbare diensten en hun gebruikers: een contractuele of reglementaire relatie?', RW I990-9I, I45; Cass. 4 december 2000, RW 2002-2003, I578I583, noot A. VAN OEVELEN; RvS 27 september I988, nr. 364.488 en F. VANDENDRIESSCHE, W. GELDHOF en A. CARTON, 'De aard van de rechtsverhoudingen in nutssectoren: reglementair of contractueel?' in I. CLAEYS, R. STEENNOT en M. TISON (eds.), Economisch recht: ondernemingen, concurrenten en consumenten, Mechelen, Kluwer, 20II, 202-203. 
Overigens werkt het gelijkheidsbeginsel ook in privaatrechtelijke (contractuele) rechtsverhoudingen door, ${ }^{116}$ zodat de overheid ook bij het gebruik van privaatrechtelijke technieken de verplichting heeft om in gelijke omstandigheden personen gelijk te behandelen. ${ }^{117}$

De toepassing van het grondwettelijk gelijkheidsbeginsel houdt dus niet noodzakelijk in dat de rechtsverhouding tussen dienstverlener en gebruikers reglementair is.

\section{c. Eenzijdige wijzigingsbevoegdheid}

44. Wellicht was de eenzijdige wijzigingsbevoegdheid door de overheid indertijd voor de Raad van State de belangrijkste reden om de rechtsverhouding tussen elektriciteitsdistributeur en gebruikers als reglementair te beschouwen. ${ }^{\mathrm{II} 8} \mathrm{Het}$ is inderdaad zo dat bij het uitoefenen van een openbare dienst in bepaalde omstandigheden wijzigingen of aanpassingen geboden zijn in het licht van de veranderende eisen van het algemeen belang. Dit is de draagwijdte van het veranderlijkheidsbeginsel, dat speelt bij het uitoefenen van alle openbare diensten (zie nr. 28 e.v.). Toch kan ook dit standpunt niet volledig worden gevolgd. Een eenzijdige wijzigingsbevoegdheid kan inderdaad een belangrijke aanwijzing zijn om te besluiten tot een reglementaire verhouding, maar betekent niet dat er altijd sprake is van een reglementaire rechtsverhouding. Dergelijke bevoegdheden kunnen immers evenzeer voorkomen in een contractuele rechtsverhouding. Het overeenkomstenrecht verzet er zich niet tegen dat aan een contractspartij een eenzijdige wijzigingsbevoegdheid wordt toegekend, d.i. de bevoegdheid om de rechten en verplichtingen van de wederpartij te wijzigen, zelfs lopende de overeenkomst. Ook aan het veranderlijkheidsbeginsel kan met andere woorden worden tegemoetgekomen via het privaatrecht, nl. via een zgn. toetredingsovereenkomst die één van de partijen de bevoegdheid verleent om eenzijdig de inhoud van de overeenkomst te wijzigen ('partijbeslissing') (zie nr. 77 e.v.). ${ }^{\text {I19 }}$

45. Tegelijkertijd valt echter niet te ontkennen dat de bevoegdheid om derden te binden een belangrijk - zo niet het belangrijkste aspect - is van een reglementaire rechtsverhouding. De bevoegdheid om in het algemeen belang eenzijdig de rechten en verplichten van derden te bepalen, is immers een bijzonder prerogatief van de overheid. ${ }^{120}$ De voorrang van het algemeen op het private belang van burgers

II6 Zie bijv. GwH Io november 20II, nr. I66/20II, overweging B.56.2.

II7 W. VAN GERVEN, De overheid in het verbintenissenrecht - Hoe blauw is het bloed van de prins?, Kluwer, Antwerpen, $1984,58$.

II8 RvS 27 september I988, nr. 30.876. Zie daarover in detail K.-J. VANDORMAEL, 'De rechtsverhouding tussen openbare diensten en gebruikers: van reglementaire of contractuele aard? (noot bij Rb. Limburg I9 december 2014)', Limb. Rechtsl. 2015, I89.

II9 Over de geldigheidsvoorwaarden van partijbeslissingsbedingen, zie I. SAMOY en A. MAES, 'Over het beding dat de bevoegdheid verleent om een partijbeslissing te nemen en de vraag of de opname van objectieve criteria noodzakelijk is voor de geldigheid ervan' (noot bij Gent, I3 oktober 2008, nr. 2007/AR/I033), TBBR 2010, 309-3I4.

I20 Het Hof van Cassatie spreekt van een imperiumbevoegdheid wanneer een instelling beslissingen kan nemen die derden binden wanneer 'zij de eigen verplichtingen tegenover anderen eenzijdig kan bepalen of verplichtingen van de anderen eenzijdig kan vaststellen' (Cass. I4 februari I997, Arr. Cass. I997, 22I; RW I996-I997, I433, concl. G. DUBRULLE, 'Gimvindus' (vaste rechtspraak)). 
en ondernemingen verklaart waarom het bestuur deze bijzondere positie inneemt in het rechtsverkeer. ${ }^{12 \mathrm{I}} \mathrm{Om}$ reglementaire van niet-reglementaire verhoudingen te onderscheiden kan de bevoegdheid om eenzijdig rechten en verplichtingen te wijzigen dan ook dienen als aanwijzing, zij het slechts als een (indicatief) vermoeden. ${ }^{122}$ Hiertoe is weliswaar vereist dat de (door de overheid opgerichte of erkende) rechtspersoon die belast is met de uitvoering van de openbare dienst daadwerkelijk beschikt over de bevoegdheid om reglementen op te stellen die bindend zijn voor de gebruikers ervan. ${ }^{123}$ Het feit dat een dergelijke bevoegdheid voorligt, betekent echter niet dat er steeds en in alle omstandigheden sprake is van een reglementaire rechtsverhouding. Een dergelijke bevoegdheid kan immers, zoals aangegeven, ook in contractuele rechtsverhoudingen voorkomen.

\section{d. Monopoliepositie}

46. In het hierboven reeds vermelde arrest van de Raad van State van 27 september I988 wordt terloops opgemerkt dat de betrokken openbare dienst 'zelfs tot overheidsmonopolie - monopolie van de gemeenten - is gemaakt'. ${ }^{124}$ Dit argument, dat de Raad eerder ten overvloede aanhaalde om de rechtsverhouding tussen de elektriciteitsdistributeur en de gebruikers als reglementair te kwalificeren, kan wel degelijk overtuigend worden aangewend als argument voor een reglementaire rechtsverhouding. ${ }^{125} \mathrm{Zo}$ vloeit de reglementaire rechtsverhouding tussen netbeheerder en gebruikers in het bijzonder voort uit de vaststelling dat elektriciteitsnetbeheerders opereren binnen een wettelijk monopolie. ${ }^{\mathrm{I} 26}$ In een monopoliesituatie is vrije toestemming van de

I2I F. VANDENDRIESSCHE, 'De invulling van het begrip administratieve overheid na de arresten Gimvindus en BATC van het Hof van Cassatie', RW 2000-200I, 497-506. Ook voor het begrip 'administratieve overheid' uit artikel I4 RvS-wet (en dus voor de toetsingsbevoegdheid van de Raad van State, zie verder/hoger) wordt het al dan niet beschikken over derdenbindende bevoegdheid aangewend om uit te maken of privaatrechtelijke instellingen administratieve overheden zijn. Zie daarover K.-J. VANDORMAEL, 'commentaar bij art. 3I-35 RvS.-wet' in W. TIMMERMANS (ed.), Wet en duiding: publiek procesrecht, Brussel, Larcier, 20I4, te verschijnen. Het is echter in de praktijk niet altijd even makkelijk te bepalen of en wanneer een instelling derdenbindende bevoegdheden uitoefent.

I22 In dezelfde zin (zij het niet indicatief, maar imperatief) I. CLAEYS, 'Normenhiërarchie en afwijkingen van (aansprakelijkheids)wetgeving in reglementaire verhoudingen (noot bij Cass. 8 maart 2012), RW 2013-I4, I663.

I23 Gebaseerd op Cass. 30 mei 20II, C.Io.0508.N. Zie daarover K.-J. VANDORMAEL en J. VANPRAET, 'Bevoegde overheden en geschillenbeslechting' in J. DE HERDT en J. KERREMANS (eds.), Wet en duiding - Sportrecht, Brussel, Larcier, 2013, 644 e.v.

I24 RvS 27 september I988, nr. 30.876, overweging 2.3.I.

I25 In dezelfde zin F. VANDENDRIESSCHE, W. GELDHOF en A. CARTON, 'De aard van de rechtsverhoudingen in nutssectoren: reglementair of contractueel?' in I. CLAEYS, R. STEENNOT en M. TISON (eds.), Economisch recht: ondernemingen, concurrenten en consumenten, Mechelen, Kluwer, 20II, 206 e.v.

I26 De elektriciteitsdistributienetten mogen enkel beheerd worden door één distributienetbeheerder die door de Vlaamse Reguleringsinstantie voor de electriciteits- en gasmarkt (VREG) wordt aangewezen voor een geografisch afgebakend gebied, zodat de gebruiker zijn netbeheerder niet vrij kan kiezen (artikel 4.I.I Energiedecreet); Zie daarover K.-J. VANDORMAEL, 'De rechtsverhouding tussen openbare diensten en gebruikers: van reglementaire of contractuele aard? (noot bij Rb. Limburg I9 december 2014)', Limb. Rechtsl. 2015, 193. In dezelfde zin: F. COUSY, 'De Vlaamse distributienetbeheerders voor elektriciteit en de bescherming van de consument', DCCR 2007, I56-I57; zie echter het onderscheid tussen het hoogspanningsnet (contractuele aard) en het laagspanningsnet (reglementaire aard) bij: 
wederpartij immers problematisch bij gebrek aan een alternatieve contractspartij, ${ }^{127}$ zeker indien het essentiële basisbehoeften betreft. Zowel de medecontractant als de geleverde goederen en diensten zijn in dat geval niet substitueerbaar. ${ }^{228}$ In dat geval kan ook de theorie van de partijbeslissing moeilijk toepassing vinden omdat er in een monopoliesituatie in feite geen vrije wilsovereenstemming mogelijk is, en men dus ook niet vrij kan instemmen met de bevoegdheid van de tegenpartij om de wederzijdse rechten en verplichtingen eenzijdig te bepalen of te wijzigen. Het gebrek aan keuzevrijheid lijkt zich in dat geval te verzetten tegen een contractuele rechtsverhouding.

Ook bij dit onderscheidingscriterium moeten echter enkele voorbehouden worden gemaakt. Tegenwoordig is het zo dat taken van openbare diensten, als gevolg van de liberalisering, steeds vaker niet in een juridische monopoliesituati $\mathrm{e}^{\mathrm{I} 29}$ worden uitgevoerd. ${ }^{130}$ Steeds meer taken die vroeger via een overheidsmonopolie werden uitgeoefend, worden vandaag verricht in een vrije marktsituatie en dus binnen een louter contractuele verhouding. ${ }^{\mathrm{I3}}$ In tegenstelling tot een juridisch monopolie kan een feitelijke monopoliesituatie niet leiden tot een kwalificatie als reglementaire rechtsverhouding omdat er in dat geval geen wettelijke grondslag voorhanden is waarop de reglementaire bevoegdheid kan worden gesteund en de kwalificatie niet mag afhangen van de feitelijke marktpositie van een dienstverlener. ${ }^{132}$ Overigens gaat een wettelijk monopolie vrijwel altijd gepaard met verregaande regulering. De wet voorziet in dat geval immers in specifieke (publiekrechtelijke) beschermingsmechanismen en procedures om misbruik van de monopoliesituatie te beperken en om te verzekeren dat de monopolist zijn taken effectief en behoorlijk uitvoert. ${ }^{133}$

F. VANDENDRIESSCHE, W. GELDHOF en A. CARTON, 'De aard van de rechtsverhoudingen in nutssectoren: reglementair of contractueel?' in I. CLAEYS, R. STEENNOT en M. TISON (eds.), Economisch recht: ondernemingen, concurrenten en consumenten, Mechelen, Kluwer, 20II, 227-228.

I27 F. VANDENDRIESSCHE, W. GELDHOF en A. CARTON, 'De aard van de rechtsverhoudingen in nutssectoren: reglementair of contractueel?' in I. CLAEYS, R. STEENNOT en M. TISON (eds.), Economisch recht: ondernemingen, concurrenten en consumenten, Mechelen, Kluwer, 20II, 206.

I28 Ook de aanbieder zelf heeft in een dergelijke situatie overigens in principe de plicht om zijn diensten te verstrekken aan eenieder die hierom verzoekt. Zie E. DIRIX, 'Algemene contractsvoorwaarden en monopolies' (noot onder Antwerpen 20 januari 1987), RW I986-1987, 2724; C. DELFORGE en J. GERMAIN, 'Le conommateur et les services publics. Etude de droit privé' in H. DUMONT, P. JADOUL et al. (eds.), Le service public: passé, present et avenir, Brugge, Die Keure, 2009, 445-446.

I29 Een juridisch monopolie is een monopolie dat wordt vastgelegd door de wetgever. In de regelgeving moet met andere woorden een grondslag bestaan voor de toekenning van bijzondere of exclusieve rechten.

I30 F. VANDENDRIESSCHE, W. GELDHOF en A. CARTON, 'De aard van de rechtsverhoudingen in nutssectoren: reglementair of contractueel?' in I. CLAEYS, R. STEENNOT en M. TISON (eds.), Economisch recht: ondernemingen, concurrenten en consumenten, Mechelen, Kluwer, 20II, 206.

I3I Wanneer een bepaalde sector volledig is geliberaliseerd, lijkt een reglementaire kwalificatie niet meer vol te houden (D. YERNAULT, 'L'impact pour les communes de l'évolution de la notion de service public dans les secteurs de l'eau et de l'energie', RDC 2002, II6).

I32 Zie daarover F. VANDENDRIESSCHE, W. GELDHOF en A. CARTON, 'De aard van de rechtsverhoudingen in nutssectoren: reglementair of contractueel?' in I. CLAEYS, R. STEENNOT en M. TISON (eds.), Economisch recht: ondernemingen, concurrenten en consumenten, Mechelen, Kluwer, 20II, 205-207.

I33 F. VANDENDRIESSCHE, W. GELDHOF en A. CARTON, 'De aard van de rechtsverhoudingen in nutssectoren: reglementair of contractueel?' in I. CLAEYS, R. STEENNOT en M. TISON (eds.), Economisch recht: ondernemingen, concurrenten en consumenten, Mechelen, Kluwer, 20II, 220-22I. 
Dit verhindert niet dat de wetgever, zelfs in het kader van een juridisch monopolie, alsnog in een contractuele kwalificatie voorziet, bijv. in relaties tussen dienstaanbieder en gebruikers.

\subsection{Behoefte aan eenduidigheid}

47. De huidige tendens in de rechtspraak lijkt alvast om rechtsverhoudingen eerder welwillend als reglementair te kwalificeren. Het bovenstaande maakt echter duidelijk dat de rechtspraak allerminst consequent is bij de verantwoording daartoe en dat de criteria die door de rechtspraak worden aangewend niet steeds duidelijk of doorslaggevend zijn.

48. De loutere verwijzing in de cassatierechtspraak naar de openbare dienst om de reglementaire aard te verantwoorden lijkt alleszins te kort te doen aan de waarborgen en de remedies die het privaatrecht kan bieden om een evenwicht tussen publieke en private belangen te realiseren. Het verdient veeleer de voorkeur om pas te besluiten tot een reglementaire rechtsverhouding na een gedetailleerde analyse van de totstandkoming en de inhoud van de rechtsverhouding in kwestie. ${ }^{134}$ Deze genuanceerde benadering, die door de Raad van State wordt gehanteerd m.b.t. beheerscontracten (zie nr. 6o), wordt in het algemeen goed onthaald in de rechtsleer, niet in het minst omdat het recht doet aan de diversiteit aan verschijningsvormen, en het de rechten van de gebruikers van de openbare dienst versterkt. ${ }^{135}$

Waar het bij openbare dienstverlening in essentie om gaat, is een correcte afweging tussen algemene en private belangen. De overheid en de rechter moeten hierbij voldoende oog hebben voor de bescherming van fundamentele waarden en belangen, alsook voor de rechtsbescherming van de gebruikers. De relativiteit van privaatrechtelijke overeenkomsten verhindert immers dat derden rechten putten uit de interne gevolgen van een overeenkomst (zie nr. 96). Een verscherpte aandacht is hierbij ontegensprekelijk vereist wanneer de openbare dienst met een juridische monopoliesituatie gepaard gaat.

I34 RvS I3 oktober 2008, nr. I87.032. Het ging in het bijzonder om volgende redenen: de afwijking van de contractsvrijheid, het verbod om ontbindende bedingen op te nemen, de vereiste goedkeuring door de regering, de bekendmaking in het Belgisch Staatsblad en het toezicht op de uitvoering door een administratieve overheid. Hierbij dient weliswaar te worden opgemerkt dat het louter afleiden van het statuut uit de afwijkingen van het gemene recht in feite neerkomt op een cirkelredenering omdat het oorzaak en gevolg verwart. Zie S. LIERMAN, Besturen zonder grenzen. Over grijze zones en blinde vlekken, Acta Falconis, VIII, Antwerpen, Intersentia, 2015, 22 e.v. Zie ook B. PEETERS, 'De verhouding tussen openbare diensten en haar gebruikers: een contractuele of een reglementaire relatie', RW I990-9I, I40.

I35 D. DEOM, 'Le contrat de gestion démasqué. Variations sur les vrais et faux contrats, les droits subjectifs et la compétence du Conseil d'Etat', APT 20I0, 4II, e.v.; D. DE ROY, 'Les contrats de gestion, des entreprises publiques ne sont pas ... des contrats', JT 2009, I40-I42; zie ook reeds vóór de besproken rechtspraak van de Raad van State: F. VANDENDRIESSCHE, Publieke en private rechtspersonen. Naar een graduele, meerduidige en evolutieve benadering van het onderscheid in de wetgeving en de rechtspraak, Brugge, Die Keure, 2004, 213, voetnoot 7I9. 


\section{$4 \quad$ Bijzondere overheidsovereenkomsten en hun afwijkingen van het privaatrecht}

49. In wat volgt worden een aantal specifieke overheidsovereenkomsten geanalyseerd, waarbij zal worden onderzocht op welke punten deze overeenkomsten een van het gemeen recht afwijkend statuut genieten. We bespreken achtereenvolgens de concessie van openbare dienst (I), de domeinconcessie (2), de beheerscontracten (3) en de beleidsovereenkomsten (4), omdat deze overeenkomsten allemaal in mindere of meerdere mate expliciet door de rechtspraak erkende afwijkingen van het gemene contractenrecht vertonen.

Deze afwijkingen houden in het bijzonder verband met de deels reglementaire kwalificatie van de rechtsverhouding, de eenzijdige wijzigbaarheid of beëindiging, de afwijking van contractuele sancties bij wanprestatie of de doorwerking van andere publiekrechtelijke regels en beginselen zoals de beginselen van de openbare dienst. Net zoals dat het geval is bij de vraag of een bepaalde rechtsverhouding als reglementair of contractueel moet worden gekwalificeerd of de vraag naar het toepassingsgebied van de beginselen van behoorlijk bestuur, ontbreekt ook voor deze bijzondere overheidsovereenkomsten een duidelijk omlijnd afbakeningscriterium of normatief referentiekader, behoudens dan dat men ook hier de rechtvaardiging van afwijkingen van het gemeen recht zoekt in de vereisten van algemeen belang.

50. Meer geïnstitutionaliseerde rechtsfiguren of rechtsverhoudingen, zoals de overheidsopdrachtenreglementering, het ambtenarenrecht of de samenwerkingsovereenkomsten tussen publiekrechtelijke organismen onderling, vallen buiten het bestek van dit preadvies, juist omwille van het feit dat de wetgever (Europees, nationaal of deelstatelijk), voor deze rechtsfiguren een uitdrukkelijk en omvattend van het gemeen recht afwijkend regime heeft ontwikkeld. Omwille van hun eigenheid en volledigheid worden deze rechtsfiguren niet behandeld. Naarmate dit publiekrechtelijke kader uitbreiding kent, krimpt overigens de ruimte die is weggelegd voor het privaatrecht. ${ }^{136}$

\section{I Concessie van openbare diensten}

5I. De concessie van een openbare dienst (hierna ook: 'concessie') is een (administratief) contract, waarbij de overheid een particulier (of ander publiekrechtelijk orgaan) (tijdelijk) opdracht geeft een openbare dienst uit te oefenen, op eigen kosten en risico, tegen een vergoeding die normaliter op de gebruikers wordt verhaald,

I36 Ter illustratie: in een arrest van II september 2014 oordeelde het Hof van Justitie dat voor zover de schending van de overheidsopdrachtenregelgeving niet kan resulteren in de onverbindendverklaring van de overeenkomst in de zin van de Richtlijn 2007/66/EG van II december 2007 (Rechtsbeschermingsrichtlijn), er ook geen beroep kan worden gedaan op eventuele gemeenrechtelijke rechtsfiguren die de overeenkomst haar rechtsgevolgen ontneemt (bijv. nietigheidsleer). Zie HvJ C-I9/I3, Ministero dell'Interno v. Fastweb SpA, 20I4. Zie hierbij F. VANDENDRIESSCHE en J. CARLÉ, 'Kan een overheidsopdracht die niet meer onverbindend kan worden verklaard, wel nog nietig worden verklaard?', ТBP 2015, afl. 6, 331. 
maar onder het gezag (toezicht) van de overheid en mits naleving van de door haar bepaalde voorwaarden. ${ }^{137}$

\section{Reeds geruime tijd neemt het Hof van Cassatie aan dat de concessie een over-} eenkomst 'sui generis' is die niet uitsluitend door de regels van het burgerlijk recht wordt beheerst. ${ }^{13^{8}}$ De reden hiervoor moet volgens het Hof worden gezocht in het voorwerp zelf van de concessie (een 'openbare dienst') en de doeleinden van openbaar nut die door de concessiegevende overheid worden nagestreefd ('het algemeen belang').

Hoewel deze analyse niet door eenieder wordt gedeeld, ${ }^{139}$ neemt de rechtsleer in navolging hiervan veelal aan dat de concessie een gemengde rechtshandeling is die deels van contractuele, en deels van reglementaire aard is. ${ }^{100}$ In essentie zouden de oprichting en de wijze van exploitatie van een openbare dienst eenzijdig en

I37 A. MAST, J. DUJARDIN, M. VAN DAMME en J. VANDE LANOTTE, Overzicht van het Belgisch administratief recht, Mechelen, Kluwer, 20I4, I68. De concessie van openbare diensten moet worden onderscheiden van de concessie voor openbare werken en de domeinconcessie. Een concessie voor openbare werken is een overeenkomst waarbij de overheid de uitvoering gunt van een bouwwerk bestemd voor gebruik door de overheid, waarbij in de regel de overheid aan het einde van de overeenkomst het eigendomsrecht op het bouwwerk verwerft in ruil voor het recht op exploitatie ervan door de 'concessiehouder' gedurende het tijdsbestek van de overeenkomst, al dan niet gepaard gaand met een vergoeding (voor de concessiehouder), of een retributie (voor de overheid). Een domeinconcessie is een overeenkomst waarbij de overheid de toelating geeft om tijdelijk en tegen vergoeding (privatief) gebruik te maken van goederen die behoren tot het openbaar domein, zonder daarbij 'positieve prestaties' in het algemeen belang op te leggen aan de 'concessiehouder' (zie nr. 57 ev.).

I38 Cass. 3I mei I978, RW I878-I979, kol. I229-I233.

I39 In zijn proefschrift komt S. VAN GARSSE na een grondige analyse (van publiek- en privaatrecht) tot de conclusie dat de domeinconcessie en de concessie voor openbare werken en diensten als gewone contracten moeten worden beschouwd met geen of slechts een geringe rol voor (administratiefrechtelijke) afwijkende regels, met dien verstande dat concessies voor openbare werken in de meeste gevallen aan de overheidsopdrachtenreglementering zijn onderworpen (S. VAN GARSSE, De concessie in het raam van publiek-private samenwerking: een analyse van het openbaar en het privaat domein, van de domeinconcessies, de concessies van openbare werken, de concessies van diensten en hun aanbesteding, Brugge, Die Keure, 2007, 237 e.v., 453 e.v. en 64I e.v.).

I40 J. MERTENS, 'De contractuele verantwoordelijkheid van de openbare besturen', TBP I948, II8; P. ORIANNE, La loi et le contrat dans les Concessions de service public, Brussel, Larcier, I96I, 84; M.-A. FLAMME, Traité théorique et pratique des marchés publics, Brussel, Bruylant, I969, I38; M. BOSMANS, 'De verhouding tussen het privé contractenrecht en het publiekrecht', RW I985-86, 2103; W. VAN GERVEN, De overheid in het verbintenissenrecht: hoe blauw is het bloed van de prins?, Antwerpen, Kluwer, I984, 66; W. VAN GERVEN en M. WYCKAERT, 'Overeenkomsten met de overheid', TPR I987, I7I7; D. D'HOOGHE, 'Overeenkomsten met de overheid' in M. STORME, Y. MERCHIERS en J. HERBOTS (eds.), De overeenkomst vandaag en morgen, Antwerpen, Kluwer, I990, I58; M. PÂQUES, De l'acte unilatéral au contrat dans l'action administrative, Brussel, Story-Scientia, I99I, I92; R. ANDERSEN, 'Autorité et contrat dans l'admnistration moderne en Belgique', Annuaire Européen d'administration Publique I997, 37; D. DEOM, 'Les instruments du droit administratif à l'épreuve des partenariats public-privé' in X. (eds.), Les partenariats public-privé: un défi pour le droit des services publics, Brugge, Die Keure, 2005, I97; A. MAST, J. DUJARDIN, M. VAN DAMME en J. VANDE LANOTTE, Overzicht van het Belgisch administratief recht, Mechelen, Kluwer, 20I4, I69, e.v.; S. VAN GARSSE, De concessie in het raam van publiek-private samenwerking: een analyse van het openbaar en het privaat domein, van de domeinconcessies, de concessies van openbare werken, de concessies van diensten en hun aanbesteding, Brugge, Die Keure, 2007 , 406 e.v. 
reglementair worden vastgesteld, terwijl het contractuele aspect wordt vereenzelvigd met de verbintenis van de concessionaris om de openbare dienst te verzekeren in ruil voor bepaalde financiële voordelen. Het reglementaire aspect betreft dan de regels verbonden aan de geconcessioneerde dienst, zoals bijv. het tarief dat mag worden gerekend voor gebruikers, de duur van de dienst of de modaliteiten ervan.

53. De rechtspraak en de rechtsleer leiden uit dit gemengde karakter van de concessie van een openbare dienst af dat deze overeenkomst is onderworpen aan een aantal specifieke, van het gemeen recht afwijkende rechtsregels. ${ }^{\text {III }}$ Er worden immers bepaalde prerogatieven aan de concessiehouder verleend die eigen zijn aan de overheid (het beheer van een openbare dienst, het innen van rechten, enz.). Deze regels zijn hoofdzakelijk terug te brengen tot de zogenoemde beginselen van de openbare dienst, waarvan het toepassingsgebied de rechtsfiguur van de concessie overstijgt.

54. Zo kan de overheid in het algemeen belang eenzijdig de exploitatievoorwaarden van de dienst wijzigen, niettegenstaande het bestaan van een contract en een lastenkohier waarin de wederzijdse rechten en plichten van de concessiegevende overheid en de concessiehouder zijn vastgelegd. ${ }^{142}$ Deze wijzigingsmogelijkheid bestaat zelfs indien het contract daarover niets voorziet en kan zelfs expliciet ingaan tegen de bepalingen van het contract of het lastenkohier. De wijzigingen verplichten niet enkel de concessiehouder, maar binden ook de gebruikers van de openbare dienst. Hoewel het contract tussen overheid en concessiehouder voor de gebruikers een 'res inter alios acta' is, kunnen zij zich tegen de concessiehouder op deze reglementaire bepalingen beroepen, maar zijn de gebruikers evenzeer gebonden door eventuele wijzigingen hierin (bijv. een tariefverhoging die de overheid in de reglementaire bedingen aanbrengt). ${ }^{\text {I43 }}$

De concessiehouder heeft in principe wel recht op vergoeding van de schade waartoe deze wijzigingen aanleiding geven. Twee hypotheses zijn in dat geval mogelijk: ofwel voorziet de overeenkomst zelf in een schadeloosstelling en de modaliteiten daarvoor, ofwel niet. In het eerste geval moet de situatie worden afgehandeld overeenkomstig het gemeen contractenrecht en met toepassing van de in het contract voorziene sancties. In het andere geval moet, zelfs indien de overeenkomst daaromtrent niets voorziet, de overheid de benadeelde concessiehouder vergoeden (tenzij andersluidend contractueel beding). Deze vergoeding moet in principe integraal zijn, en dus niet alleen het geleden verlies ('damnum emergens'), maar ook de winstderving ('lucrum cessans') dekken die de concessie-

I4I Over het feit dat de concessie is onderworpen aan bepaalde van het gemene recht afwijkende regels lijkt wel eensgezindheid te bestaan in de rechtsleer. Zie daarover MAST, J. DUJARDIN, M. VAN DAMME en J. VANDE LANOTTE, Overzicht van het Belgisch administratief recht, Mechelen, Kluwer, 20I4, I73 e.v.

I42 Zie reeds Brussel, 8 januari I877, Pas. I877, I36; RvS 26 oktober I949, nr. I42; Cass. 4 september I958, Pas. I959, I, 7; Cass. 3I mei I978, Arr. Cass. I978, II59; RvS 2 januari I993, nr. 4I.878; Cass. 25 september 2000, Arr. Cass. 2000, 49I en RvS I4 maart 2000, nr. 85.875 (zij het over een domeinconcessie).

I43 MAST, J. DUJARDIN, M. VAN DAMME en J. VANDE LANOTTE, Overzicht van het Belgisch administratief recht, Mechelen, Kluwer, 20I4, I69. 
houder redelijkerwijze had kunnen verwachten bij de normale uitvoering van de overeenkomst. ${ }^{\mathrm{I} 4}$ De grondslag voor de compensatievergoeding, daarentegen, is weliswaar betwist. Sommige auteurs verwijzen naar het principe van de gelijkheid van de burgers voor openbare lasten, ${ }^{145}$ anderen kijken naar het contractenrecht (artikel II 35 BW) ${ }^{146}$, nog anderen betrachten de synthese en hebben het over 'une responsabilité contractuelle objective [...] qui trouve sa justification dans le principe de l'égalité devant les charges publiques' ${ }^{\prime 24}$.

Ook wordt door de rechtspraak algemeen aanvaard dat de overheid de concessieovereenkomst eenzijdig mag beëindigen, zelfs indien dit niet formeel in het concessiecontract is bedongen. ${ }^{\mathrm{I} 8}$ Deze beëindigingsmogelijkheid van de overheid moet als het ware als 'stilzwijgend vervat in de overeenkomst' worden aangenomen gelet op, aldus het Hof van Cassatie, de aard en het voorwerp van de overeenkomst. Het beginsel van de veranderlijkheid van de openbare dienst rechtvaardigt dat te allen tijde wordt teruggekomen op de concessievoorwaarden of het bestaan zelf van de concessieovereenkomst. ${ }^{\text {I49 }}$

Aangezien de rechtspraak deze beëindigingsmogelijkheid baseert op de rechten en plichten waarop de partijen krachtens de overeenkomst aanspraak kunnen maken, zijn deze beslissingen in principe niet vatbaar voor een schorsings- of vernietigingsberoep bij de Raad van State. ${ }^{150}$

55. Bovendien wordt algemeen aangenomen dat de concessiehouder, behoudens overmacht, onder geen enkel voorwendsel de exploitatie mag onderbreken tijdens de duur van de concessie. Ook deze regel zou teruggaan op de beginselen van de openbare dienst, meer specifiek het continuïteitsbeginsel, al wordt hiertegen

I44 Cass. 4 september I958, Pas. I959, I, 7, concl. P. MAHAUX.

I45 H. DE PAGE, Traité élémentaire de droit civil belge, tome V., Brussel, Bruylant, I94I, 7I3.

I46 S. VAN GARSSE, De concessie in het raam van publiek-private samenwerking: een analyse van het openbaar en het privaat domein, van de domeinconcessies, de concessies van openbare werken, de concessies van diensten en hun aanbesteding, Brugge, Die Keure, 2007, 299; zie ook voor een toepassing van de gewone regels inzake contractuele wanprestatie wanneer de overheid haar contractuele verplichtingen miskent: Gent, I9 november 1959, Pas. I96I, II, I4.

I47 B. GORS, 'Le principe de mutabilité' in X. (eds.), Le service public 2. Les 'lois' du service public, Brussel, la Charte, 2009, (I05) I29.

I48 Cass. Io mei I929, Pas. I929, I, I83; Cass. 4 september I958, Pas. I959, I, 7, concl. P. MAHAUX, Cass. 3 I mei I978, Arr. Cass. 1978, I59; Gent, I9 november I959, Pas. I961, II, I4.

I49 Cass. 3I mei 1978, Arr.Cass. I978, I59; M.-A. FLAMME, Traité théorique et pratique des marchés publics précédé d'un essai de théorique générale des contrats de l'administration en droit belge et en droit comparé, Brussel, Bruylant, I969, nr. I20; A. BUTTGENBACH, Manuel de droit administratif, Brussel, Larcier, Ig66, 365. Zie hierover ook D. D'HOOGHE, 'Bestuurlijke vrijheid geklemd tussen de beginselen inzake rechtszekerheid, wettigheid en veranderlijkheid', RW I993-94, IIo2.

I50 Het is vaste rechtspraak van de Raad van State dat beslissingen van de overheid om het contract te beëindigen of te wijzigen niet losstaan van de uitvoering van het contract en daarom ook niet vatbaar zijn voor schorsing of vernietiging bij de Raad van State; zie bijv. RvS 28 maart 2000, nr. 86.268; RvS 22 november 2004, nr. I37.4I7. Zie echter verder (nr. 59 ev., 'de domeinconcessie') de bespreking van een arrest van de Raad van State waarin de Raad zich toch bevoegd verklaart om kennis te nemen van een beeïndigingsbeslissing van een domeinconcessie door een (zij het onbevoegd) college van burgemeester en schepenen 
aangevoerd dat deze verplichting even goed zou kunnen voortvloeien uit de betrokken contractuele verbintenissen. ${ }^{151}$

De concessiegever is verplicht tot stipte naleving van zijn verplichtingen en moet alles doen om het goede en regelmatige functioneren van de dienst te waarborgen. ${ }^{152}$ Hij bezit in dat opzicht dan ook niet alle rechten van een gewone medecontractant. ${ }^{53}$ Zo mag de concessiehouder in principe wel optreden indien de overheid in gebreke blijft bij het uitvoeren van haar verbintenissen, maar zal hij principieel de 'exceptio non adimpleti contractus' (enac) niet kunnen inroepen om zijn prestaties te schorsen. ${ }^{154}$

56. Ten slotte vereist het beginsel van de benuttigingsgelijkheid nog dat principieel alle burgers ten aanzien van het gebruik van de openbare dienst (door de concessiehouder) gelijk worden behandeld. ${ }^{155}$ Het gaat hier eigenlijk om niet meer dan de concretisering van het grondwettelijk gelijkheidsbeginsel (artikelen io en II Gw.) dat ook doorwerkt in privaatrechtelijke rechtsverhoudingen. ${ }^{156}$ De verplichting van de overheid om in gelijke omstandigheden personen gelijk te behandelen geldt evenzeer wanneer de overheid privaatrechtelijke technieken gebruikt. ${ }^{157}$

Uit het gelijkheidsbeginsel vloeit nog voort dat de overheid bij het verlenen van concessies een passende mate van openbaarheid moet garanderen om de mededinging te laten spelen, zelfs buiten het toepassingsgebied van de overheidsop-

I5I A. MAST, J. DUJARDIN, M. VAN DAMME en J. VANDE LANOTTE, Overzicht van het Belgisch administratief recht, Mechelen, Kluwer, 20I4, I76-I77. Zie, over dit laatste: S. VAN GARSSE, De concessie in het raam van publiek-private samenwerking: een analyse van het openbaar en het privaat domein, van de domeinconcessies, de concessies van openbare werken, de concessies van diensten en hun aanbesteding, Brugge, Die Keure, 2007,508 . De concessiehouder verbindt er zich immers vaak uitdrukkelijk toe gedurende een welbepaalde termijn, onder alle omstandigheden, op een bestendige wijze bepaalde prestaties te verrichten. Zie ook reeds P. ORIANNE, La loi et le contrat dans les Concessions de service public, Brussel, Larcier, I961, I83.

I52 A. MAST, J. DUJARDIN, M. VAN DAMME en J. VANDE LANOTTE, Overzicht van het Belgisch administratief recht, Mechelen, Kluwer, 2914, I76-I77.

I53 Daarnaast kan hij ook gehouden zijn tot naleving van specifieke wetgeving, zoals de taalwetgeving (Artikel I, SI, $2^{\circ}$ wetten van I8 juli I 66 op het gebruik der talen in bestuurszaken, BS 2 augustus I966).

I54 P. ORIANNE, La loi et le contrat dans les Concessions de service public, Brussel, Larcier, I96I, II4; W. VAN GERVEN, De overheid in het verbintenissenrecht: hoe blauw is het bloed van de prins?, Antwerpen, Kluwer, I984, 68; A. MAST, J. DUJARDIN, M. VAN DAMME en J. VANDE LANOTTE, Overzicht van het Belgisch administratief recht, Mechelen, Kluwer, 20I4, 177. Daarbij past wel de kritische kanttekening dat de opschorting van sommige prestaties niet noodzakelijk de openbare dienstverlening zelf in het gedrang brengt. Zie daarover B. PEETERS, De continuiteit van het overheidsondernemen, Antwerpen, Maklu, 1989, 420 en S. VAN GARSSE, De concessie in het raam van publiek-private samenwerking: een analyse van het openbaar en het privaat domein, van de domeinconcessies, de concessies van openbare werken, de concessies van diensten en hun aanbesteding, Brugge, Die Keure, 2007, 507.

I55 RvS 2 mei 20II, nr. 2I2.886; RvS 27 september I988, nr. 364.488.

I56 Zie bijv. GwH Io november 20II, nr. I66/20II, overweging B.56.2.

I57 W. VAN GERVEN, De overheid in het verbintenissenrecht - Hoe blauw is het bloed van de prins?, Kluwer, Antwerpen, I984, 58. 
drachtenreglementering. ${ }^{158}$ Hoewel de rechtspraak strenger is ten aanzien van concessieovereenkomsten, ${ }^{159}$ is dit in feite een toepassing van de algemene regel dat voor alle overheidsovereenkomsten een zekere vorm van 'inmededingingstelling' moet worden georganiseerd door de overheid. ${ }^{160}$

\subsection{Domeinconcessie}

57. Een domeinconcessie is een overeenkomst waarbij de overheid toestemming geeft om tijdelijk en tegen vergoeding (privatief) gebruik te maken van goederen die behoren tot het openbaar domein, maar dan zonder daarbij 'positieve prestaties' in het algemeen belang op te leggen aan degene aan wie de concessie wordt toegekend. ${ }^{161}$ Hoewel de domeinconcessie dus losstaat van de exploitatie van een openbare dienst, is het in de praktijk niet altijd even gemakkelijk om de domeinconcessie duidelijk te onderscheiden van de concessie van openbare dienst. ${ }^{162}$

58. Domeinconcessies worden traditioneel beschouwd als administratieve overeenkomsten doordat de overheid bepaalde van het gemeen recht afwijkende bevoegdheden behoudt. Dit bijzondere statuut wordt doorgaans afgeleid uit het feit dat openbare domeingoederen buiten de handel zijn. Men neemt dan ook aan dat elk recht op openbare domeingoederen precair is en als herroepbaar moet worden beschouwd, zij het ook hier meestal onder de voorwaarde van betaling van een schadevergoeding (zie nr. 54, 'concessie van openbare diensten'). ${ }^{163}$ Deze eenzijdige wijzigingsmogelijkheid is inherent aan de domeinconcessie. Particulieren kunnen op deze goederen immers slechts privatieve rechten verkrijgen in de mate dat daarmee geen afbreuk wordt gedaan aan hun bestemming of het recht van het bestuur om het gebruik ervan te regelen of te wijzigen volgens de vereisten van het algemeen belang. ${ }^{164} \mathrm{Om}$ dezelfde reden wordt aangenomen dat de concessiehouder

I58 RvS 22 november I995, nr. 56.4I0; RvS 5 december 2002, nr. II3.343; zie ook HvJ C-324/07, Coditel Brabant NV v. gemeente Ukkel, 2008; A. MAST, J. DUJARDIN, M. VAN DAMME en J. VANDE LANOTTE, Overzicht van het Belgisch administratief recht, Mechelen, Kluwer, 20I4, I70; S. VAN GARSSE, De concessie in het raam van publiek-private samenwerking: een analyse van het openbaar en het privaat domein, van de domeinconcessies, de concessies van openbare werken, de concessies van diensten en hun aanbesteding, Brugge, Die Keure, 2007, 695-696.

I59 Zie bijv. RvS 3 I mei 1979, nr. I9.67I.

I6o Zie daarover in detail: K. WAUTERS, Rechtsbescherming en overheidsovereenkomsten, Antwerpen, Intersentia, 2009, I46-I53. Zo zal de overheid in principe bij alle overeenkomsten die zij sluit moeten nagaan of er (meerdere) potentiële contractspartijen in aanmerking komen, hieraan de nodige openbaarheid verlenen, en, indien van toepassing, deze geïnteresseerden ook de kans moeten geven hun interesse kenbaar te maken.

I6I A. MAST, J. DUJARDIN, M. VAN DAMME en J. VANDE LANOTTE, Overzicht van het Belgisch administratief recht, Mechelen, Kluwer, 20I4, I68.

I62 Zie daarover B. PEETERS, De continuïteit van het overheidsondernemen, Antwerpen, Maklu, I989, 265; A. MAST, J. DUJARDIN, M. VAN DAMME en J. VANDE LANOTTE, Overzicht van het Belgisch administratief recht, Mechelen, Kluwer, 20I2, I68-I69.

I63 Voor toepassingen zie RvS 29 oktober I98I, nr. 2I.5I7; RvS 2 januari I993, nr. 4I.878; Cass. 25 september 2000, Arr. Cass. 2000, 49I.

I64 Cass. 25 september 2000, Arr. Cass. 2000, 49I; D. D'HOOGHE, 'Overeenkomsten met de overheid', in: M. STORME, Y. MERCHIERS en J. HERBOTS, De overeenkomst vandaag en morgen, Antwerpen, Kluwer, I990, I47. 
op grond van deze overeenkomst niet kan beschikken over zakelijke rechten, doch slechts over een subjectief recht dat tegenstelbaar is aan derden. ${ }^{165}$ De rechtspraak en de wetgever aanvaarden echter steeds vaker dat binnen het openbaar domein ook zakelijke rechten kunnen worden toegestaan (zie nr. I4).

59. Ondanks dit bijzondere statuut bestaat doorgaans eensgezindheid over het contractuele karakter van de domeinconcessie. ${ }^{\mathrm{I} 66}$ In de rechtsleer gaan zelfs stemmen op om de domeinconcessie als een gewoon civielrechtelijk contract te beschouwen, waarbij het eenzijdig wijzigingsrecht voortvloeit uit de aard en het voorwerp zelf van de domeinconcessie. ${ }^{167}$ De contractuele kwalificatie houdt in dat bij uitsluiting de gewone rechter bevoegd is om uitspraak te doen over de geschillen m.b.t. de uitvoering van de concessie. De Raad van State heeft het laken echter gedeeltelijk naar zich toegetrokken door de domeinconcessie te kwalificeren als een complexe handeling, die wordt gekenmerkt door een element van gezag en een contractueel element. ${ }^{168}$ Ondanks de vaste rechtspraak van de Raad van State om geen kennis te nemen van beslissingen van de overheid om een overeenkomst te beëindigen of te wijzigen (zie nr. 23), verklaarde de Raad van State zich wel bevoegd om kennis te nemen van een beslissing waarbij een (daartoe onbevoegd) college van burgemeester en schepenen een einde maakte aan een domeinconcessie. ${ }^{69}$ De Raad van State vond de verantwoording hiervoor in de bijzondere aard van dit contract 'mêlant des éléments contractuels et d'autorité', waardoor het niet volledig door het burgerlijke recht wordt beheerst. De beslissing die een einde maakte aan de concessie om redenen van algemeen belang is dan niet genomen 'en vertu de sa composante contractuelle mais d'autorité' en kan bijgevolg als administratieve rechtshandeling voorwerp uitmaken van een vernietigingsberoep bij de Raad van State.

Dit laatste arrest illustreert de aanhoudende discussie over de bijzondere aard van de domeinconcessie. Ongeacht of de rechtspraak deze verhouding echter een contractueel dan wel een deels publiekrechtelijk jasje aanmeet, blijft het gezochte evenwicht hetzelfde, namelijk tussen het private gebruik en de publieke bestemming van het openbare domein.

I65 A. MAST, J. DUJARDIN, M. VAN DAMME en J. VANDE LANOTTE, Overzicht van het Belgisch administratief recht, Mechelen, Kluwer, 20I2, 320.

I66 Zie echter L. DERIDDER en T. VERMEIR, Leidingen voor nutsvoorzieningen, Brugge, die Keure, 200o, I3-I4; de auteurs zien in de domeinconcessie een vermomde eenzijdige domeinvergunning.

I67 D. D'HOOGHE, 'Overeenkomsten met de overheid', in: M. STORME, Y. MERCHIERS en J. HERBOTS, De overeenkomst vandaag en morgen, Antwerpen, Kluwer, I990, I47-I48; D. D'HOOGHE en P. DE KEYSER, 'Het continuïteitsbeginsel en het veranderlijkheidsbeginsel', in: I. OPDEBEEK en M. VAN DAMME, Beginselen van behoorlijk bestuur, Brugge, Die Keure, 2006, 39I-392; S. VAN GARSSE, De concessie in het raam van de publiek-private samenwerking, Brugge, die Keure, 2007, 252, e.v., 317. Hierbij moet dan wel rekening worden gehouden met de bijzondere positie van de overheid (A. VAN OEVELEN, De overheidsaansprakelijkheid voor het optreden van de rechterlijke macht, Antwerpen, Kluwer, I987, nr. I59; M. BOES, 'Bestuurlijke vrijheid en rechterlijke toetsing', RW I987-I988, I249; D. D'HOOGHE, 'Overeenkomsten met de overheid', in: M. STORME, Y. MERCHIERS en J. HERBOTS, De overeenkomst vandaag en morgen, Antwerpen, Kluwer, I990, I48).

I68 RvS I4 maart 2000, nr. 85.875, ro. 4.9.2; RvS 25 september 2007, nr. I74.964.

I69 RvS 25 september 2007, nr. I74.964. 


\subsection{Beheerscontracten}

6o. Beheerscontracten zijn overeenkomsten gesloten tussen de overheid en een overheidsbedrijf, waarin de bijzondere regels en voorwaarden zijn opgenomen waaronder deze bedrijven hun opdrachten vervullen. ${ }^{170}$ Een beheerscontract bevat bepalingen zoals de taken van het overheidsbedrijf, de tariefbepaling, gedragsregels en eventuele sancties en wordt gekenmerkt door de nadruk op het wederzijdse karakter van de verbintenissen en het procedé van onderhandelingen waaruit die verbintenissen resulteren. ${ }^{\mathrm{I} T \mathrm{I}}$

Volgens de rechtspraak van de Raad van State moet de rechtsaard van (clausules uit) beheerscontracten ad hoc, dit wil zeggen bepaling per bepaling en geval per geval, worden nagegaan. ${ }^{172}$ Zo werd het beheerscontract tussen de Franse Gemeenschap en de RTBF door de Raad van State gekwalificeerd als reglementair na een gedetailleerde analyse van de totstandkoming en de inhoud van het beheerscontract. Dit was het geval omdat het beheerscontract op essentiële punten afweek van het gemeen recht, nl. de afwijking op het principe van de contractsvrijheid, het verbod om ontbindende bedingen op te nemen, de vereiste goedkeuring door de regering, de bekendmaking in het Belgisch Staatsblad en het toezicht op de uitvoering door een administratieve overheid. ${ }^{173}$ Het Hof van Cassatie weigerde in eerdere rechtspraak echter deze clausules te kwalificeren als 'wetten in de zin van artikel 608 van het Gerechtelijk Wetboek' (waaronder ook reglementen vallen). ${ }^{174}$

6r. De diversiteit aan beheerscontracten maakt het in de praktijk moeilijk, zo niet onmogelijk, om algemene regels te distilleren die van toepassing zijn op alle beheersovereenkomsten. ${ }^{175}$ In elk van deze gevallen zoekt de rechtspraak naar een legitimatie om correcties op het gemeen recht te rechtvaardigen. In het vorige hoofdstuk werden een aantal criteria gedistilleerd die dienstig kunnen worden aangewend om de rechtsverhoudingen in een beheerscontract te kwalificeren als reglementair dan wel contractueel, met alle gevolgen vandien (zie nr. 4I e.v.). Dit neemt niet weg dat de wetgever soms zelf uitdrukkelijk afwijkt van het gemeen verbinte-

I70 Zie daarover o.m. S. BAETEN, De overheid als ondernemer, Brugge, Die Keure, 2003, 337-354; D. DEOM, 'Les contraintes de droit public qui pèsent sur les entreprises publiques' in Les entreprises publiques autonomes, Brussel, Bruylant, I992, II9-I23; L. DERIDDER, 'De beheerscontracten in federaal, communautair en gewestelijk perspectief' in X. (eds.), Onderneming van publiekrecht, Antwerpen, Maklu, 2000, 267-303; W. DEVROE, 'Deugdelijk bestuur van overheidsondernemingen', TRV I998, 487-488; H. MATTHIJS, 'De overheidsbedrijven: een nieuw management met beheerscontracten of privatiseren', ТВP I997, 307-316.

I7I F. VANDENDRIESSCHE, Publieke en private rechtspersonen. Naar een graduele, meerduidige en evolutieve benadering van het onderscheid in de wetgeving en de rechtspraak, Brugge, Die Keure, 2004, 2 II.

I72 RvS I3 oktober 2008, nr. I87.032.

I73 RvS I3 oktober 2008, nr. 187.032; de Raad van State achtte zich bevoegd om te beoordelen of de beslissing van de controle-instantie - Conseil supérieur de l'audiovisuel - waarbij de RTBF een administratieve sanctie werd opgelegd wegens schending van de reclameregels in het beheerscontract, was gebaseerd op een verkeerde interpretatie van deze regeling; zie ook: RvS 9 juni 2010, nr. 204.956.

I74 Cass. 2I december 2000, JT 2002, 402.

I75 In dezelfde zin D. DE ROY, 'La nature juridique des contrats de gestion des entreprises publiques: à la recherche de l'introuvable ?', JT 2002, 397-398. 
nissenrecht. Zo onttrekt de wet van 2I maart I99I betreffende de hervorming van sommige economische overheidsbedrijven de beheerscontracten aan de toepassing van artikel II $84 \mathrm{BW}$, waardoor de rechterlijke ontbinding van deze beheerscontracten is uitgesloten. ${ }^{176}$

\subsection{Beleidsovereenkomsten}

62. Een beleidsovereenkomst of 'convenant' is een door de overheid met een particulier (of andere overheid) gesloten overeenkomst waarin het beleid van die overheid wordt vormgegeven of uitgevoerd. ${ }^{177}$ Traditioneel wordt een viertal grote categorieën van beleidsovereenkomsten onderscheiden, ${ }^{178} \mathrm{al}$ is het in de praktijk niet altijd even gemakkelijk om deze indeling te volgen:

- beleidsovereenkomsten in de strikte zin zijn beleidsovereenkomsten waarbij het algemeen beleid wordt vormgegeven, zoals bijv. de Zwartbergakkoorden m.b.t. de sluiting van de koolmijnen;

- programmaovereenkomsten zijn overlegovereenkomsten waarbij de overheid afspraken maakt met een bepaalde sector met het oog op de tenuitvoerlegging van overheidsbeleid, zoals bijv. in het kader van prijzenreglementering of zogenoemde milieubeleidsovereenkomsten;

- aanvullende beleidsovereenkomsten zijn overeenkomsten ter vervollediging (of in afwijking) van wettelijke of reglementaire regels, zoals bijv. de overeenkomsten in uitvoering van de economische expansiewetgeving van 30 december 1970, of ook inzake de prijzenreglementering;

- zelfstandige beleidsovereenkomsten zijn overeenkomsten bij ontstentenis van wettelijke of reglementaire regels, zoals bijv. de bankprotocollen tussen de bankcommissie (CBFA) en de individuele banken. ${ }^{179}$

I76 Artikel 3, \$3 wet van 2I maart I99I betreffende de hervorming van sommige economische overheidsbedrijven, BS, 27 maart I99I, err. BS, 20 juli I99I.

I77 W. VAN GERVEN, Beleidsovereenkomsten. Academiae Analecta, Brussel, Paleis der Academiën, I984, 48. Meer recent: J. DEBIĒVRE, 'Het convenant als beleidsinstrument naar Belgisch recht: achtergrond en recente evolutie', TuW 2002, 367.

I78 Zie daarover J. LE BRUN, 'l'administration économique par voie contractuelle en Belgique' in X. (eds.), Renaissance du phénomène contractuel, I97I, 40 e.v.; C. CAMBIER, 'Les contrats de programme' in X. (eds.), Misc. W.J. Ganshof van der Meersch, Brussel, Bruylant, I972, 435 e.v.; W. VAN GERVEN, Beleidsovereenkomsten. Academiae Analecta, Brussel, Paleis der Academiën, I984, 58-50; B. PEETERS, 'Convenanten, in het bijzonder milieuconvenanten' in X. (eds.), Vereniging voor de vergelijkende studie van het recht van België en Nederland: preadviezen 1994, Zwolle, W.E.J. Tjeenk Willink, I994, 20 e.v.; J. DEBIÈVRE, 'Het convenant als beleidsinstrument naar Belgisch recht: achtergrond en recente evolutie', TuW 2002, 367 e.v.; K. LEUS, 'Overeenkomsten met de overheid en overheidsovereenkomsten: bijzondere overeenkomsten en algemeen belang. De 'gemene', de 'gemengde' of de 'zuivere' rechtsleer?' in X. (eds.), Bijzondere overeenkomsten, XXXIVe Postuniversitaire cyclus W. Delva, 20072008, Mechelen, Kluwer, 426 e.v.

I79 (Eigen terminologie). Zie daarover (en over de voorbeelden) in detail W. VAN GERVEN en M. WYCKAERT, 'Overeenkomsten met de overheid', TPR I987, I746 e.v. 
63. Elk van deze beleidsovereenkomsten is in principe volledig onderworpen aan het gemeen verbintenissenrecht. Zo wordt, althans voor milieubeleidsovereenkomsten, aangenomen dat zij als wederkerige overeenkomsten zijn onderworpen aan de gemeenrechtelijke bewijsregels (artikel I325 e.v. BW), de enac (II84 BW) en de risicoleer (als één van de partijen door overmacht haar verbintenissen niet kan uitvoeren is de medecontractant in beginsel evenmin gehouden zijn verbintenissen na te komen). ${ }^{\text {I80 }}$ Dit neemt niet weg dat de toepassing van deze regels vaak aanleiding geeft tot praktische problemen. Zo is de afdwingbaarheid en de handhaving van dergelijke beleidsovereenkomsten vooral psychologisch van aard, en dikwijls zelfs problematisch. ${ }^{\mathrm{I} 8 \mathrm{r}}$ Beleidsovereenkomsten worden immers gekenmerkt door een lager juridisch gehalte en een beperkt bindend karakter, gelet op de aard van de materie en de wil van de partijen. ${ }^{182}$ Zo bevatten de meeste (milieu) beleidsovereenkomsten geen enkele controle- of sanctieregeling, behoudens in uitzonderlijke gevallen een rapporteringsplicht aan de bevoegde overheid. ${ }^{183}$ Daarbij komt dat burgers (en milieuverenigingen) in de regel derden zijn ten aanzien van deze overeenkomsten en dus, krachtens het beginsel van de relativiteit van overeenkomsten, de naleving ervan niet kunnen eisen van de contracterende ondernemingen (zie hoofdstuk 5). ${ }^{184}$

64. Onder de voorwaarden van de Belgische tweewegenleer staat niets de overheid in de weg om haar beleid via deze overeenkomsten vorm te geven. Dit mag er echter niet toe leiden dat de overheid haar bevoegdheid geheel en op voorhand aan banden legt. De overheid mag zich ertoe verbinden haar bevoegdheid op een welbepaalde manier te gebruiken, maar niet om geen gebruik te maken van een haar toekomende bevoegdheid. ${ }^{185}$ Het contract mag er niet toe leiden dat de overheid vooruitloopt op een vergunningsbeslissing en zo publiekrechtelijke voorwaarden en procedures omzeilt, zoals een openbaar onderzoek, een termijnregeling of een adviesverplichting. Dit publiekrechtelijke kader beoogt niet in het minst de bescherming van particulieren tegen het overheidsoptreden en kan elementen naar voren brengen die in de contractuele verhouding niet ter sprake kwamen. ${ }^{186}$

I80 A. VAN OEVELEN, 'Privaatrechtelijke aspecten van milieubeleidsovereenkomsten' in H. BOCKEN en I. TRAEST (eds.), Milieubeleidsovereenkomsten, Brussel, Story, I99I, I9-20.

I8I M. PAQUES 'Les conventions sectorielles en matière d'environnement du point de vue du droit public' in H. BOCKEN en I. TRAEST (eds.), Milieubeleidsovereenkomsten, Brussel, Story, I99I, 5I-52.

I82 J. LE BRUN, 'l'administration économique par voie contractuelle en Belgique' in X. (eds.), Renaissance du phénomène contractuel, I97I, 63 e.v.; W. VAN GERVEN, Beleidsovereenkomsten. Academiae Analecta, Brussel, Paleis der Academiën, I984, 50; M. PAQUES 'Les conventions sectorielles en matière d'environnement du point de vue du droit public' in H. BOCKEN en I. TRAEST (eds.), Milieubeleidsovereenkomsten, Brussel, Story, I99I, 44 e.v.

I83 M. PAQUES 'Les conventions sectorielles en matière d'environnement du point de vue du droit public' in H. BOCKEN en I. TRAEST (eds.), Milieubeleidsovereenkomsten, Brussel, Story, I99I, 32.

I84 M. PAQUES 'Les conventions sectorielles en matière d'environnement du point de vue du droit public' in H. BOCKEN en I. TRAEST (eds.), Milieubeleidsovereenkomsten, Brussel, Story, I99I, 52.

I85 C. CAMBIER, 'Les contrats de programme' in X. (eds.), Misc. W.J. Ganshof van der Meersch, Brussel, Bruylant, I972, 452.

I86 Zie ook in die zin (i.v.m. bestuursbemiddeling): E. LANCKSWEERT, 'Naar een faciliterende wetgeving voor bemiddeling met openbare besturen', TBP 2010, 520-52I. 
Ook de Raad van State neemt aan dat de overheid zich rechtsgeldig kan verbinden, op voorwaarde dat ze blijft binnen haar toegewezen bevoegdheden en op voorwaarde dat deze contractuele binding de overheid niet belet 'op normale en behoorlijke wijze van zijn vrije beoordeling van het algemeen belang gebruik te maken' en 'het gelijkheidsbeginsel na te leven'. ${ }^{187}$ De overheid is dan ook verplicht de kern van haar discretionaire bevoegdheid ongemoeid te laten, en 'moet steeds bevoegd blijven de beleidsovereenkomst op elk moment te herzien of zelfs te beëindigen als het algemeen belang zulks vereist en dit ongeacht enige andersluidende contractuele clausule maar desgevallend mits het toekennen van een schadevergoeding' ${ }^{188}$ De rechtsleer vindt de rechtvaardiging voor deze (impliciete) wijzigings- en opzeggingsmogelijkheid, zelfs in afwezigheid van een contractuele clausule in die zin, in de (wisselende) vereisten van het algemeen belang, zodat ook deze afwijking van het gemeen recht in wezen kan worden teruggebracht op een toepassing van het veranderlijkheidsbeginsel. ${ }^{189}$

65. Hoewel de overheid in een beleidsovereenkomst niet mag vooruitlopen op een latere vergunningsbeslissing, kunnen de contractuele afspraken wel als basis dienen voor toekomstige bestuurshandelingen. ${ }^{190}$ Het staat de overheid overigens niet vrij om zomaar terug te komen op gemaakte contractuele afspraken. Dit zou nl. indruisen tegen de beginselen van behoorlijk bestuur, meer bepaald het zorgvuldigheids-, het motiverings- en het vertrouwensbeginsel. ${ }^{\text {III }}$ Goede redenen om af te wijken van de overeenkomst kunnen bijvoorbeeld wel volgen uit de bezwaren die derden uitten tijdens het openbare onderzoek of uit de al dan niet verplichte adviezen van andere overheidsinstanties. ${ }^{192}$

De overheid die in een beleidsovereenkomst haar eigen discretionaire beoordelingsruimte bij het nemen van latere bestuurshandelingen inperkt, dreigt het deksel op de neus te krijgen. Hoewel de overeenkomst zelf niet het voorwerp kan uitmaken van een annulatieberoep, is dat wel zo voor de bestuurshandelingen die erop volgen. In het ophefmakende Uplace-dossier oordeelde de Raad van State dat de Vlaamse Regering zich in een beleidsovereenkomst, nl. een brownfield-convenant, te ver had geëngageerd door afspraken op te nemen over de inhoud van de vergunning. ${ }^{193}$ Brownfield-convenanten zijn overeenkomsten naar burgerlijk recht, waarbij de overheid (Vlaamse gewest), samen met private (projectontwik-

I87 Ontwerp van wet betreffende de economische expansie, Parl.St. Senaat I969-70, 354, 58.

I88 W. VAN GERVEN, Beleidsovereenkomsten. Academiae Analecta, Brussel, Paleis der Academiën, I984, 6o-62; W. VAN GERVEN en M. WYCKAERT, 'Overeenkomsten met de overheid', TPR I987, I750I75I. W. VAN GERVEN, De overheid in het verbintenissenrecht: hoe blauw is het bloed van de prins?, Antwerpen, Kluwer, I984, 89 .

I89 W. VAN GERVEN en M. WYCKAERT, 'Overeenkomsten met de overheid', TPR I987, I750-I75I

I90 Zie ook (i.v.m. bestuursbemiddeling): E. LANCKSWEERDT, 'Bemiddeling (mediation)' in X. (eds.), Welzijnsgids, Mechelen, Kluwer rechtswetenschappen, losbl., afl. februari 2004, I53.

I9I Zie ook (i.v.m. bestuursbemiddeling): E. LANCKSWEERT, 'Naar een faciliterende wetgeving voor bemiddeling met openbare besturen', TBP 2010, 52I.

I92 Zie ook (i.v.m. bestuursbemiddeling): E. LANCKSWEERT, 'Naar een faciliterende wetgeving voor bemiddeling met openbare besturen', TBP 2010, 520-52I.

I93 RvS 28 mei 20I4, nr. 227.578, ro. 25-29; het beroep bij het Hof van Cassatie (als attributierechter) werd afgewezen: Cass. I9 februari 2015, C.I4.0308.N, concl. A-G C. VANDEWAL; RW 20I4-I5, I665, noot C. BERX. 
kelaars e.a.) en andere publiekrechtelijke actoren (vergunningverlenende overheden) modaliteiten, afspraken en steunmaatregelen overeenkomt met betrekking tot het saneren en het ontwikkelen van verwaarloosde of onderbenutte (dikwijls vervuilde) gronden. ${ }^{194}$ In het bijzonder had de Vlaamse Regering zich ertoe verbonden om de milieuvergunning enkel te weigeren in welbepaalde omstandigheden, namelijk om redenen van openbaar belang of om redenen die niet op redelijke wijze te remediëren zijn. Omdat de overheid niet meer 'in alle objectiviteit, zonder vooringenomenheid en zonder gebonden te zijn door eerder aangegane overeenkomsten' kon oordelen over de op het convenant volgende milieuvergunningsaanvraag, vernietigde de Raad van State de vergunning wegens schending van het onpartijdigheidsbeginsel. ${ }^{195}$ Het Hof van Cassatie zag er als attributierechter geen graten in dat de Raad van State verbintenissen uit de overeenkomst interpreteert wanneer dit zoals in casu noodzakelijk is om de beoordeling van de rechtmatigheid van de bestuurshandeling te kunnen toetsen. ${ }^{196}$ Hoewel de bestuursrechter de overeenkomst erg streng interpreteert, biedt het arrest een mooie illustratie dat de Raad van State ondanks zijn onbevoegdheid om uitspraak te doen over contractuele geschillen, wel onrechtstreeks via het leerstuk van de afsplitsbare handeling invloed kan uitoefenen op de contractspraktijk van het bestuur. Het arrest leidde begin 2015 immers tot de ondertekening van een hernieuwd convenant dat rekening hield met de opmerkingen van de Raad van State.

\section{$5 \quad$ Behartiging van het algemeen belang door middel van het privaatrecht}

66. Volgens de gangbare opvatting bezit de klassieke tweedeling tussen het publiekrecht en het privaatrecht een duidelijke normatieve dimensie. ${ }^{197}$ Dat overheidshandelen traditioneel onderworpen is aan een bijzonder statuut - het publiekrecht wordt immers verantwoord vanwege haar speciale opdracht: de behartiging van het algemeen belang. Op deze grond beschikt een overheid over verschillende privileges, waarvan de eenzijdige beslissingsbevoegdheid uiteraard het meest in het oog springt. Daartegenover staat dat het overheidsoptreden onderworpen is aan specifieke standaarden - waaronder de grondrechten en de beginselen van behoorlijk

I94 Zie artikel 2 Decreet van 30 maart 2007 betreffende de brownfieldconvenanten, BS II april 20II; Parl. St. Vl. Parl. 2006-2007, nr. I059I/I, I2.

I95 Raad van State 28 mei 20I4, nr. 227.578, r.o. 29.

I96 Cass. I9 februari 20I5, C.I4.0308.N, concl. A-G C. VANDEWAL; RW 20I4-I5, I665, noot C. BERX. In een noot bij dit arrest merkt C. BERX terecht op dat het Hof van Cassatie anders zou hebben geoordeeld indien de Vlaamse overheid de milieuvergunning zou hebben geweigerd en de NV Uplace hiertegen zou hebben aangevoerd dat de weigering onrechtmatig was omdat de Vlaamse overheid hierdoor inging tegen contractueel bedongen verplichtingen. In die hypothese is het werkelijke en rechtstreekse voorwerp van het geschil immers een betwisting van een subjectief recht dat de NV Uplace ontleent aan het brownfield-convenant, waartoe uitsluitend de gewone rechter bevoegd is (C. BERX, 'Het Hof van Cassatie ziet er geen graten in dat de Raad van State zijn rechtsmacht (ogenschijnlijk?) verder uitbreidt (noot onder Cass. I9 februari 2015), RW 2014-I5, I673).

I97 P. CANE, 'Accountability and the public/private distinction' in N. BAMFORTH en P. LEYLAND (eds.), Public law in a multi-layered constitution, Oxford, Or. Hart, 2003, $27 \mathrm{I}$. 
bestuur - die voornamelijk tot doel hebben te verzekeren dat het private belang niet volledig opgeofferd wordt aan het publieke belang. Het publiekrecht is in die zin gericht op het bewerkstelligen van een redelijk evenwicht tussen publieke en private belangen. Het privaatrecht - dat uitgaat van wilsautonomie en consensualisme daarentegen, wordt geacht gericht te zijn op de bescherming van de (private) belangen van de contracterende partijen. Traditioneel staat men dan ook eerder wantrouwig tegenover het privaatrechtelijke handelen door de overheid.

In beginsel, en behoudens andersluidende wettelijke bepalingen, wordt de uitvoering van de overeenkomst beheerst door regels van het burgerlijk recht. ${ }^{19^{8}}$ Een overheid die, binnen het kader van de tweewegenleer, beslist om haar bestuurlijke optreden op contractuele basis vorm te geven, blijft echter gehouden aan haar publieke taak. In dit verband worden vraagtekens geplaatst bij de mogelijkheden voor de overheid om op basis van het gemeen overeenkomstenrecht het algemeen belang te vrijwaren.

Daarom wordt, zoals we zagen, het publiekrecht ook soms geacht door te werken in contractuele overheidsrelaties bij de zogenoemde administratieve overeenkomsten. Maar is de toepassing van publiekrechtelijke leerstukken dan werkelijk onontbeerlijk? Is het gemeen overeenkomstenrecht zo rigide dat het niet ontvankelijk is voor een incorporatie en afweging van verschillende private en publieke belangen?

67. In wat volgt, gaan we eerst kort in op de leerstukken van de overheidsaansprakelijkheid voor onrechtmatige en rechtmatige daad. Hieruit blijkt reeds dat private leerstukken wel degelijk ruimte laten voor een afweging van publieke en private belangen. Daarna zoomen we in op het algemene contractenrecht. Op basis van een analyse van de mogelijkheden voor een overheid om een overeenkomst eenzijdig te wijzigen of te beëindigen en de verenigbaarheid van privaatrechtelijke remedies met de continuïteit van de openbare dienst gaan we na of de traditionele publieke prerogatieven onontbeerlijk zijn voor een efficiënte behartiging van het algemeen belang. Daarnaast bekijken we of de keuze door de overheid voor de privaatrechtelijke weg de wederpartij de toepassing van bepaalde specifieke publiekrechtelijke waarborgen ontzegt. Ten slotte gaan we na in hoeverre de beginselen van behoorlijk bestuur door werken in de contractuele relatie via open normen in het privaatrecht.

68. Uit deze analyse blijkt eens te meer dat het water tussen het publiekrecht en het privaatrecht niet zo diep is als traditioneel wordt aangenomen. ${ }^{199}$ De met het eenzijdig overheidsoptreden geassocieerde publiekrechtelijke prerogatieven en verplichtingen zijn niet per definitie onverzoenbaar met het gemeen overeenkomstenrecht. Doorgaans kan immers eenzelfde resultaat worden bereikt door 'in privaatrechtelijke termen te redeneren' en een beroep te doen op privaatrechtelijke

I98 D. DHOOGHE, 'Overeenkomsten met de overheid' in M. STORME, Y. MERCHIERS en J. HERBOTS (eds.), De overeenkomst vandaag en morgen, XXIe Postuniversitaire cyclus Delva, Antwerpen, Kluwer, 1990, 156.

I99 Zie tevens W. VAN GERVEN en S. LIERMAN, Algemeen deel, veertig jaar later. Privaat- en publiekrecht in een meergelaagd kader van regelgeving, rechtsvorming en regeltoepassing, Mechelen, Kluwer, 2010. 
rechtsfiguren. ${ }^{200}$ Veelzeggend in dit verband is het arrest De Leener en Ballon, waarin de Raad van State reeds aangaf dat niet a priori valt uit te sluiten dat de bepalingen in het Burgerlijk Wetboek die de uitvoering van de overeenkomst betreffen een concretisering zijn van het redelijkheidsbeginsel (zie nr. 37). ${ }^{201}$

\section{I Overheidsaansprakelijkheid als illustratie van de innige tango tussen publiek- en privaatrecht}

a. Onrechtmatige overheidsdaad: het aansprakelijkheidsrecht en argumenten van algemeen belang

69. Dat het algemeen verbintenissenrecht niet per definitie ongevoelig is voor overwegingen van publiek belang is reeds lange tijd duidelijk in de context van overheidsaansprakelijkheid. Nadat de beoordeling van overheidsoptreden in het licht van artikel $\mathrm{I}_{3} 82 \mathrm{BW}$ lange tijd gezien werd als een inbreuk op de scheiding der machten, oordeelde het Hof van Cassatie zoals eerder aangegeven in het Flandriaarrest van 5 november 1920 dat de overheid onderworpen is aan het (burgerlijk) recht, waaronder artikel $\mathrm{I}_{3} 82 \mathrm{BW}$, en dus aansprakelijk kan worden gesteld voor haar onrechtmatig handelen. Dit staat er echter niet aan in de weg dat de algemene zorgvuldigheidsnorm geconcretiseerd wordt in het licht van de normaal zorgvuldig handelende overheid die zich in dezelfde omstandigheden bevindt. Hierbij is een belangrijke rol weggelegd voor de beginselen van behoorlijk bestuur. ${ }^{202}$ Aangezien deze beginselen, die overigens op zich impliciet een afweging tussen publieke en private belangen veronderstellen, de concretisering vormen van de zorgvuldigheidsnorm, resulteert de schending van deze beginselen ook automatisch in een fout die aanleiding kan geven tot overheidsaansprakelijkheid. ${ }^{203}$

Een rechter zal zich bij de beoordeling van het al dan niet foutieve karakter van het overheidshandelen overigens steeds rekenschap dienen te geven van de appreciatiemarge die de overheid toekomt bij de organisatie van het algemeen belang. ${ }^{204}$

200 Zie in dit verband E. DROOGLEEVER FORTUIJN, 'Congruentie van privaatrechtelijke en administratiefrechtelijke begrippen' in X. (eds.), Non sine causa: opstellen aangeboden aan prof. G. J. Scholten ter gelegenheid van zijn afscheid als hoogleraar aan de Universiteit van Amsterdam, Zwolle, Tjeenk Willink, I979, 39.

201 RvS 27 september I988, nr. 30.876, De Leener en Ballon.

202 Zo dient een rechter bij de beoordeling van de redelijke termijn rekening te houden met noodwendigheden van algemeen belang (Cass. 27 oktober 2006, C.03.0584.N). Zie ook W. VAN GERVEN en S. LIERMAN, Algemeen deel, veertig jaar later. Privaat- en publiekrecht in een meergelaagd kader van regelgeving, rechtsvorming en regeltoepassing, Mechelen, Kluwer, 2010, I38-I39, nr. 52.

203 Zie o.m. Cass. 27 oktober 2006, C.03.0584.N; Brussel I6 juni 20I4, T.Vreemd. 20I4, afl. 4, 399; Brussel 3 oktober 2007, RABG 2009, afl. 9, 640; Brussel 21 mei 2003, RGAR 2004, afl. 4, nr. I3848; KG Rb. Brugge, I2 april 2000, Not.Fisc.M. 2003, afl. 8, 232, noot F. BAUDONCQ, Rb. Brugge (4e k.) 2I oktober 2013, Fisc.Koer. 2013, afl. 19-20, 682; C. BERX, 'Het Hof van Cassatie ziet er geen graten in dat de Raad van State zijn rechtsmacht (ogenschijnlijk?) verder uitbreidt' (noot onder Cass. I9 februari 20I5), RW 20I4-I5, I673. Zie meer algemeen over het verband tussen het foutbegrip en de door de Raad van State vastgestelde onwettigheid: A. MAST, J. DUJARDIN, M. VAN DAMME en J. VANDE LANOTTE, Overzicht van het Belgisch administratief recht, Mechelen, Kluwer, 2014, I077; B. WEYTS en T. VANSWEEVELT, Handboek buitencontractueel aansprakelijkheidsrecht, Antwerpen, Intersentia, 2009, 201 e.v.

204 Cass. 27 oktober 2006, C.03.0584.N. 
70. Ofschoon de specifieke hoedanigheid van de overheid invloed uitoefent op het onderdeel van de foutbeoordeling, wordt het algemeen belang niet meegenomen bij het bepalen van de gevolgen van een vaststelling van onrechtmatig handelen. De overheid is op basis van artikel $\mathrm{I}_{3} 82 \mathrm{BW}$ steeds gehouden de volledige schade te vergoeden. Argumenten van algemeen belang - zoals bijvoorbeeld een zwaarwichtige budgettaire weerslag - kunnen in dit verband geen verzachtende omstandigheid vormen. ${ }^{205}$

7I. Sinds de hervorming in 2014 beschikt de Raad van State over een meer uitgebreide set van bevoegdheden, die het ook mogelijk moeten maken een geschil finaal te beslechten. Hierbij kan worden gedacht aan de bemiddeling (artikel I9, $3^{\text {de }}$ lid RvS-wet), de injunctiebevoegdheid (artikel 35/r en 36 RvS-wet), de bestuurlijke lus (artikel $38 \mathrm{RvS}$-wet) ${ }^{206}$, maar vooral aan de mogelijkheid om in het kader van een annulatieberoep aan de verzoeker die nadeel heeft geleden ten gevolge van een onwettig bestuursbesluit een schadevergoeding tot herstel toe te kennen (artikel Irbis RvS-wet). In tegenstelling tot de gewone rechter mag de Raad van State bij de begroting van de vergoeding evenwel rekening houden met alle omstandigheden van openbaar en particulier belang. Argumenten van algemeen belang zouden dus kunnen verantwoorden dat de integrale schadevergoeding wordt beperkt. ${ }^{207}$ De toekomst zal echter uitwijzen hoe de Raad van State invulling zal geven aan zijn nieuwe bevoegdheid.

b. Rechtmatige overheidsdaad: het beginsel van de gelijkheid van burgers voor openbare lasten

72. De inclusie van overwegingen van algemeen belang in private leerstukken is nog meer uitgesproken in de context van overheidsaansprakelijkheid wegens rechtmatig handelen. Het algemene uitgangspunt in het schadevergoedingsrecht - dat eenieder geacht wordt de eigen schade te dragen - kan in deze context niet

205 Niet toevallig komt men in Frankrijk - waar i.t.t. België de bijzondere positie van de overheid traditioneel steeds centraal staat - tot een ander besluit. In het arrest Blanco van het Tribunal des Conflits van 1873 - het arrest waar ook de principiële bevoegdheid van de administratieve rechtscolleges (toen enkel nog de Conseil d'Etat) voor aansprakelijkheidsvorderingen tegen de overheid werd aanvaard - overwoog dit rechtscollege 'que la responsabilité, qui peut incomber à l'Etat [...] ne peut être régie par les principes qui sont établis dans le Code civil, pour les rapports de particulier à particulier; que cette responsabilité n'est ni générale, ni absolue, qu'elle a ses règles spéciales qui varient suivant les besoins du service et la nécessité de concilier les droits de l'Etat avec les droits privés' (Tribunal des Conflits 8 februari I873, www. legifrance.gouv.fr).

206 Dit artikel werd evenwel recent vernietigd door het Grondwettelijk Hof. Zie GwH I6 juli 20I5, nr. I03/20I5.

207 Zie voor een uitgebreide bespreking van deze nieuwe bevoegdheid H. BOCKEN, 'Beter een vogel in de hand dan tien in de lucht? De wijziging van art. I44 Grondwet en de bevoegdheid van de Raad van State om schadevergoeding toe te kennen', TOO 20I3, afl. 4, 428; M. MERCKAERT, 'Artikel I44 van de Grondwet en het toekennen van schadevergoeding tot herstel door de Raad van State' in A. ALEN, B. DALLE, K.J. MUYLLE e.a. (eds.), Het federale België na de Zesde Staatshervorming, Brugge, Die Keure, 2014, 235 e.v.; I. CLAEYS, 'Schadevergoeding wegens een onwettige bestuurshandeling voor de hoven en rechtbanken of voor de Raad van State: een moeilijke keuze?' in M. VAN DAMME (ed.), De hervorming van de Raad van State, Brugge, Die Keure, 20I4, I85. 
onverkort worden toegepast. Bijzondere wetten voorzien al veel langer in specifieke vergoedingsregelingen. ${ }^{208}$ In 2010 vond het Hof van Cassatie echter een autonome vergoedingsgrondslag voor schade ten gevolge van rechtmatig overheidsoptreden in het leerstuk van het beginsel van de gelijkheid van burgers voor openbare lasten. ${ }^{209}$ Op grond van dit principe kan een overheid niet zonder vergoeding lasten opleggen die groter zijn dan die welke een particulier in het algemeen belang moet dragen. Meer concreet gaat het dan om de gevolgen die buiten het normale maatschappelijke risico of het normale bedrijfsrisico vallen en die op een beperkte groep burgers of instellingen drukken. Twee jaar later erkende het Grondwettelijk Hof het beginsel als een toepassing van de artikelen io en II van de Grondwet, waaraan (de ontstentenis van) een vergoedingsregeling voor een rechtmatige eigendomsbeperking kan worden getoetst. ${ }^{210}$ Vooralsnog kreeg het beginsel in de rechtspraak nog geen uitwerking buiten de context van eigendomsbeperkingen.

73. Eerder deed het beginsel van de gelijkheid voor de openbare lasten al dienst als toetsingsnorm in het kader van het leerstuk van de abnormale burenhinder. Terwijl het Hof van Cassatie voor hinderverwekkende overheidsactiviteiten geruime tijd dezelfde toetsingsmaatstaven hanteerde als voor particulieren, verduidelijkte het in twee arresten van I99I dat het abnormale karakter van de door de overheid veroorzaakte hinder moet worden vastgesteld in functie van de lasten die een burger in het algemeen belang dient te ondergaan. ${ }^{21}$

74. De beoordeling van het onevenredige nadeel noopt tot een afweging van de betrokken private en publieke belangen. Volgens het Hof van Cassatie en het Grondwettelijk Hof moet rekening worden gehouden met alle omstandigheden van de zaak, onder meer de verwachtingen van de burgers in verband met de solidariteit die van hen wordt gevraagd. Andere criteria die een rol kunnen spelen, zijn de financiële draagkracht van de overheid en van de burgers, de aard van de overheidshandeling, de voorzienbaarheid van de handeling en haar gevolgen voor de getroffen burgers of ondernemingen en de aard en de omvang van de toegebrachte schade. ${ }^{212}$

208 Zie voor een overzicht D. LINDEMANS en B. VAN HERREWEGHE, 'Bijlage. Overzicht van erfdienstbaarheden van openbaar nut met specifieke vergoedingsregelingen' in R. PALMANS, W. VERRIJDT en V. SAGAERT (eds.), Eigendomsbeperkingen: de erfdienstbaarheid van openbaar nut, Antwerpen, Intersentia, 20I2, 253.

209 Cass. 24 juni 20I0, C.06.04I5.N, RW 20I0-II, afl. 29, I2I7, noot S. LIERMAN.

2IO GwH I9 april 20I2, nr. 55/20I2; zie ook GwH 27 november 20I4, nr. 170/20I4; GwH I oktober 2015, nr. 132/2015.

2 II Cass. 23 mei I99I, Arr. Cass. I990-9I, 943; Cass. 28 januari r99I, Arr. Cass. I990-9I, 572.

$2 \mathrm{I} 2 \mathrm{GwH}$ I oktober 20I5, nr. I32/20I5; zie ook C.N.J. KORTMANN en S. LIERMAN, 'Het beginsel van de gelijkheid van burgers voor openbare lasten: een beginsel op de snijlijn van publiek- en privaatrecht', TPR 20I4, afl. 2, 689; S. LIERMAN en P.-J. VAN DE WEYER, 'Recht spreken aan de hand van een pluraliteit van rechtsnormen: meer of minderwaarde voor de rechtsbescherming bij rechtmatige overheidsdaad?' in F. DERUYCK, E. GOETHALS, L. HUYBRECHTS e.a. (eds.), Amicus Curiae. Liber amicorum Marc De Swaef, Antwerpen, Intersentia, 2013, 267. 


\subsection{Ruimte in privaatrecht voor veranderende behoeften van algemeen belang?}

75. Een overheid mag de kern van haar beoordelingsbevoegdheid niet miskennen. Concreet impliceert dit dat, wat betreft duurovereenkomsten ${ }^{213}$, de bevoegdheid tot contracteren afhankelijk is van het bestaan van de nodige garanties die waarborgen dat de overheid te allen tijde op kan treden in functie van het algemeen belang (zie nr. I2). Wanneer er sprake is van een specifieke wettelijke voorziening die de eenzijdige wijziging of beëindiging van de overeenkomst mogelijk maakt, is er op dit vlak uiteraard geen probleem. ${ }^{214} \mathrm{Bij}$ afwezigheid van een dergelijke (uitdrukkelijke) voorziening, en in de wetenschap dat het bestaan van een (impliciet) algemeen beëindigingsrecht en wijzigingsrecht betwijfeld wordt, vallen we hierbij terug op het algemene verbintenissenrecht. Uit het hierna volgende overzicht blijkt dat verschillende privaatrechtelijke rechtsfiguren een wijziging of beëindiging van de overeenkomst mogelijk maken, zonder dat dit een afzonderlijke wilsovereenstemming vereist. Dit relativeert het belang van de discussie over de draagwijdte van het veranderlijkheidsbeginsel. Met het privaatrecht kan immers hetzelfde resultaat worden bereikt. ${ }^{215}$

a. Goede afspraken maken goede vrienden: anticiperen op veranderende behoeften van algemeen belang in de overeenkomst zelf

76. Duurovereenkomsten kunnen voor een bepaalde of onbepaalde duur worden aangegaan. Het is een algemeen verbintenisrechtelijk principe dat overeenkomsten van onbepaalde duur steeds door elke contractspartij eenzijdig kunnen worden opgezegd. Het gaat hier om een principe van openbare orde..$^{216}$

Dikwijls zal een overeenkomst echter worden aangegaan voor een bepaalde duur. In dat geval is er geen sprake van een principieel eenzijdig opzeggingsrecht. Om deze reden stelt een auteur dan ook voor om overeenkomsten van bepaalde duur bijv. te beperken tot de duur van een legislatuur (vijf of zes jaar). ${ }^{217}$

2I3 Bij aflopende of dadelijke overeenkomsten, waarbij de uitvoering van de overeenkomst onmiddellijk bij de contractsluiting plaatsvindt, bestaat er uiteraard geen risico op veranderende omstandigheden.

2I4 Zie bijv. artikel 6.2.4. Decreet 5 april 1995 houdende algemene bepalingen inzake het milieubeleid; artikel 37, 38 Koninklijk Besluit I4 januari 2013 tot bepaling van de algemene uitvoeringsregels voor overheidsopdrachten en concessies van openbare werken.

2 I5 Zie ook R. ANDERSEN, 'Autorité et contrat dans l'administration moderne en Belgique' in X. (eds.), Annuaire européen d'administration publique, Aix-en-Provence, P.U.A., I997, 42.

216 Cass. 9 maart 1973, Pas. 1973, I, 640; Cass. 22 november 1973, Pas. 1974, I, 312. In de regel is geen motivering vereist, maar de opzegging mag niet ontijdig gebeuren en er dient steeds een redelijke opzeggingstermijn in acht te worden genomen. In de overeenkomst kunnen desgewenst modaliteiten worden vastgelegd. Zie F. VERMANDER, De opzegging van overeenkomsten, Antwerpen, Intersentia, 20I4, 46I e.v.; P. VAN OMMESLAGHE, Les obligations (vol. 2), Brussel, Bruylant, 20I3, IO0I, nr. 657.

2 I7 K. LEUS, 'Overeenkomsten met de overheid of overheidsovereenkomsten: bijzondere overeenkomsten en algemeen belang' in R. FELTKAMP en E. JANSSENS (eds.), Ondernemingscontracten stap voor stap, Brussel, Larcier, 2013, 522 e.v. 
77. Daarnaast kan een contractspartij bij het sluiten van een overeenkomst steeds anticiperen op een toekomstige verandering in de behoeften van algemeen belang door middel van een partijbeslissing of opzegbeding.

Het beeld dat een overeenkomst steeds de vrucht is van de onderhandelingen tussen de contracterende partijen, en hierdoor in contrast staat tot het door de overheid eenzijdig opgestelde reglement, strookt niet steeds met de realiteit. De economisch sterkere partij - overigens niet noodzakelijk de overheid - is vaak in de mogelijkheid haar feitelijke overwicht juridisch om te zetten door middel van een toetredingscontract. In een toetredingscontract wordt de inhoud vooraf eenzijdig vastgelegd door één partij. Door de aanvaarding door de wederpartij komt de overeenkomst tot stand. ${ }^{218}$ In de regel is er bij dergelijke overeenkomsten - net zoals bij eenzijdig overheidsoptreden - dus weinig tot geen onderhandelingsruimte, en wordt de contractsvrijheid van de toetredende partij beperkt tot het al dan niet sluiten van het contract. De contractspartijen kunnen daarenboven overeenkomen dat één van hen de bevoegdheid krijgt de overeenkomst eenzijdig te wijzigen (partijbeslissing) of te beëindigen (opzegbeding).

Een overeenkomst moet op straffe van nietigheid op het ogenblik van contractsluiting over een bepaald, of in elk geval bepaalbaar, voorwerp beschikken. Dit staat er evenwel niet aan in de weg dat een contractspartij, meestal in het kader van een toetredingsovereenkomst, de bevoegdheid wordt verleend om eenzijdig een element van de overeenkomst te bepalen of te wijzigen. De overheid kan dus rechtsgeldig een beding in de overeenkomst opnemen dat haar toelaat het voorwerp van haar verbintenis aan te passen wanneer het algemeen belang dit vereist.

Op dezelfde manier kan een overheid zich door middel van een opzegbeding het recht voorbehouden om de overeenkomst eenzijdig te beëindigen, al dan niet onder voorwaarde van de veranderende behoeften van het algemeen belang, en al dan niet na afloop van een opzegtermijn. ${ }^{219}$ In dat geval zal de overheid zich als compensatie wel meestal verbinden tot de betaling van een opzegvergoeding. ${ }^{220}$

78. De marge van de contractspartijen bij het opstellen van deze bedingen is niet onbeperkt. Zo mogen de modaliteiten in elk geval niet van dien aard zijn dat de overheid de facto verhinderd wordt om zich op deze bedingen te beroepen bijv.

2 I 8 P. VAN OMMESLAGHE, Les obligations (vol. 1), Brussel, Bruylant, 2013, 203, nr. Io6.

2I9 F. VERMANDER, De opzegging van overeenkomsten, Antwerpen, Intersentia, 20I4, 5I3 e.v. Er dient evenwel verplicht een redelijke opzegtermijn te worden voorzien wanneer het gaat om een overeenkomst met een consument in de zin van artikel I.I. $2^{\circ}$ Wetboek Economisch Recht (artikel VI.83, II ${ }^{\circ}$ Wetboek Economisch Recht).

220 Deze vergoeding kan, maar hoeft niet, integraal te zijn. Zie S. STIJNS, De gerechtelijke en buitengerechtelijke ontbinding van overeenkomsten, Antwerpen, Maklu, I994, 353 e.v. Indien de overheidsovereenkomst is afgesloten met een consument in de zin van artikel I.I. $2^{\circ}$ Wetboek Economisch Recht moet een opzegbeding, op straffe van nietigheid, steeds ook in een schadeloosstelling voorzien (artikel VI. 83, I0 $^{\circ}$ Wetboek Economisch Recht). 
omwille van een excessieve opzegvergoeding. ${ }^{221}$ Het is daarnaast duidelijk dat de uitoefening van deze rechten steeds dient te gebeuren binnen de grenzen van de goede trouw en geen afbreuk mag doen aan de economie van het contract. ${ }^{222}$

b. Afwezigheid van eenzijdig beëindigingsrecht en/of wijzigingsrecht en de geldigheid van de overeenkomst

79. Hiervoor werd reeds duidelijk dat de bevoegdheid van de overheid tot contracteren afhankelijk is van het bestaan van voldoende waarborgen tot vrijwaring van het algemeen belang. Maar wat als deze waarborgen ontbreken? Wat indien een overheid - bij afwezigheid van een wettelijke grondslag om de overeenkomst te beëindigen of te herzien - tevens nalaat een partijbeslissing en/of opzeggingsbeding op te nemen? Welke gevolgen heeft dit voor de geldigheid van de overeenkomst?

Deze gevolgen moeten geanalyseerd worden in het licht van de vier traditionele geldigheidsvoorwaarden van een overeenkomst (artikel IIo8 BW): wilsovereenstemming, rechtsbekwaamheid en handelingsbekwaamheid, het (bepaald en geoorloofd) voorwerp, en de (geoorloofde) oorzaak. Een overeenkomst die tot stand is gekomen met miskenning van één van deze vier voorwaarden kan in principe door de rechter nietig worden verklaard. De afwezigheid van een beëindigingsrecht of wijzigingsrecht heeft mogelijk invloed op zowel de toestemming, de bekwaamheid als het voorwerp van de overeenkomst.

8o. Toestemming. Een overheid die toetreedt tot een overeenkomst zonder zich het recht voor te behouden om deze overeenkomst te beëindigen of te herzien (wanneer vereist door het algemeen belang), overschrijdt in principe haar bevoegdheid.

De discussie in de rechtsleer met betrekking tot de gevolgen van een vernietigingsarrest van de Raad van State op de toestemming van de overheid lijkt na het cassatiearrest van 5 maart 2012 definitief te zijn beslecht. ${ }^{223}$ Het Hof van Cassatie

22I Ook wanneer wordt aanvaard dat een overheid van rechtswege de bevoegdheid bezit om in het algemeen belang terug te komen op de aangegane verbintenissen, zijn de mogelijkheden voor contractspartijen om hiervoor in bepaalde modaliteiten te voorzien zeer beperkt. Zie B. GORS, 'Le principe de mutabilité' in X. (eds.), Le service public 2. Les 'lois' du service public, Brussel, la Charte, 2009, I52.

222 Cass. 9 november 2006, C.05.02I8.F. In geval van rechtsmisbruik beschikt de rechter over een matigingsbevoegdheid. S. VAN GARSSE, De concessie in het raam van publiek-private samenwerking: een analyse van het openbaar en het privaat domein, van de domeinconcessies, de concessies van openbare werken, de concessies van diensten en hun aanbesteding, Brugge, Die Keure, 2007, 303.

223 Sommige auteurs verdedigden dat deze toestemming wegviel (F. BELLEFLAMME, 'L'annulation de la décision d'attribution d'un contrat administratif et ses conséquences civiles', APT 20II, 267; K. WAUTERS, Rechtsbescherming en overheidsovereenkomsten, Antwerpen, Intersentia, 2009, 315). Andere auteurs betwistten dit omdat, zo meenden zij, de aanwezigheid of afwezigheid van wilsovereenstemming net zoals de overige geldigheidsvoorwaarden beoordeeld dient te worden op het moment van de totstandkoming van de overeenkomst (D. D'HOOGHE en N. KIEKENS, 'Tenuitvoerlegging van arresten van de Raad van State inzake overheidsopdrachten' in I. COOREMAN, 
oordeelde in dit arrest dat een vernietiging door de toezichthoudende overheid van een beslissing tot sluiting van een arbeidsovereenkomst ook de toestemming met de overeenkomst retroactief deed verdwijnen. ${ }^{224}$ Voor vernietigingsarresten van de Raad van State moet logischerwijze dezelfde redenering opgaan. Afwezigheid van toestemming geeft in principe aanleiding tot relatieve nietigheid. ${ }^{225}$

8I. Bekwaamheid. Ook zonder tussenkomend vernietigingsarrest kan een rechter een overeenkomst nietig verklaren. Een overheid kan niet over de eigen bevoegdheid beschikken. Er zou dan ook kunnen worden geoordeeld dat een overheid niet rechtsbekwaam is om een overeenkomst te sluiten zonder dat in de mogelijkheid wordt voorzien om eenzijdig in te grijpen wanneer het algemeen belang dit vereist. $\mathrm{Nu}$ het principe van de onbeschikbaarheid van overheidsbevoegdheden van openbare orde is, betreft het hier een absolute nietigheid. ${ }^{226}$

82. Voorwerp. Op dezelfde grond kan besloten worden tot de aanwezigheid van een ongeoorloofd voorwerp. Het Hof van Cassatie beschouwt een voorwerp als niet geoorloofd wanneer het 'een onwettige toestand mogelijk maakt of in stand houdt'. ${ }^{227}$ In die zin kan worden aangenomen dat een overheid die de eigen beslissingsbevoegdheid blijvend beperkt een onwettige toestand creëert. ${ }^{228}$ Logischerwijze gaat het ook hier om een absolute nietigheid.

83. Oorzaak. Voor de volledigheid kijken we hier ook nog naar de oorzaak, als zelfstandige geldigheidsvereiste voor verbintenissen en overeenkomsten. De oorzaak van een verbintenis geldt als de voornaamste beweegreden voor een partij om zich te verbinden. ${ }^{229}$ De aan- of de afwezigheid van een bevoegdheid om eenzijdig in de

D. LINDEMANS en L. PEETERS (eds.), De tenuitvoerlegging van de arresten van de Raad van State, Brugge, die Keure, 20I2, 4I9). Deze kritiek lijkt echter voorbij te gaan aan de retroactieve werking van een vernietigingsarrest. De afsplitsbare rechtshandeling verdwijnt immers ex tunc uit het rechtsverkeer. Anders is het voor de beslissing van de gewone rechter tot het buiten toepassing laten van de afsplitsbare rechtshandeling op grond van artikel $159 \mathrm{Gw}$. Deze beslissing heeft immers geen invloed op het bestaan van de rechtshandeling, waardoor ook de toestemming van de overheid bij het sluiten van de overeenkomst onaangetast blijft.

224 Cass. 5 maart 2012, S.o9.0096.F.

225 Cass. 2i oktober I97I, Arr.Cass. I972, I88. Zie ook F. BELLEFLAMME, 'L'annulation de la décision d'attribution d'un contrat administratif et ses conséquences civiles', APT $2011,267$.

226 B. GORS, 'Le principe de mutabilité' in X. (eds.), Le service public 2. Les 'lois' du service public, Brussel, la Charte, 2009, I52; S. VAN GARSSE, De concessie in het raam van publiek-private samenwerking: een analyse van het openbaar en het privaat domein, van de domeinconcessies, de concessies van openbare werken, de concessies van diensten en hun aanbesteding, Brugge, Die Keure, 2007, 505.

227 Cass. 8 april 1999, C.98.0042.F.

228 Vgl. met de situatie waarin de overheid overgaat tot vervreemding van goederen die tot het openbaar domein behoren. Ook hier is de sanctie absolute nietigheid wegens ongeoorloofd voorwerp. Zie D. BATSELÉ, T. MORTIER en M. SCARCEZ, Algemeen administratief recht, Brussel, Bruylant, 20I2, 484.

229 P. VAN OMMESLAGHE, Les obligations (vol. 1), Brussel, Bruylant, 2013, 328, nr. I95. Sommige auteurs vatten het oorzaakbegrip evenwel op als een dualistisch concept en maken een onderscheid tussen de interne/objectieve oorzaak (de inwendige rechtvaardiging van een verbintenis) en de externe/subjectieve oorzaak (de voornaamste beweegredenen om zich te verbinden). Het onderzoek naar de geoorloofdheid van een oorzaak gebeurt alleszins aan de hand van het subjectieve oorzaakbegrip. Zie A. DE BOECK, 'Oorzaak' in E. DIRIX en A. VAN OEVELEN (eds.), Bijzondere overeenkomsten. Artikelsgewijze commentaar met overzicht van rechtspraak en rechtsleer, 
overeenkomst in te grijpen heeft hierop geen rechtstreekse invloed. Er zal slechts sprake zijn van een ongeoorloofde oorzaak - resulterend in een absolute nietigheid $^{230}$ - wanneer de overeenkomst strekt tot beperking van de beschikkingsbevoegdheid van de overheid. In het overheidsopdrachtencontentieux heeft het Hof van Beroep te Brussel geoordeeld dat een overheid die, na een schorsing of vernietiging van een gunningsbeslissing door de Raad van State, zich verschuilt achter de overeenkomst om desondanks de overheidsopdracht te continueren, de overeenkomst aanwendt om de regels inzake overheidsopdrachten buiten spel te zetten. Het ging dan om bepalingen die het Hof als van openbare orde kwalificeerde. Het Hof oordeelde dat in zulk geval sprake was van een ongeoorloofde oorzaak. ${ }^{23} \mathrm{De}$ aanwezigheid van de geldigheidsvoorwaarden van een overeenkomst moet echter worden beoordeeld op het ogenblik van de contractsluiting. Bijgevolg valt moeilijk in te zien hoe een beslissing, na een schorsing of vernietiging van de beslissing tot contracteren, om de overeenkomst te continueren, invloed kan uitoefenen op de motieven die aanwezig waren bij het aangaan van de overeenkomst. Inmiddels kwam het Hof overigens op deze rechtspraak terug. ${ }^{232}$

84. Een overheid die nalaat een opzegbeding en/of partijbeslissing op te nemen in een overeenkomst, en zo mede aan de basis ligt van een mogelijke nietigheid, zou mogelijk wel aansprakelijk kunnen worden gesteld door de wederpartij wegens een culpa in contrahendo. ${ }^{233}$

85. Wegens de zwaarwichtige gevolgen is het niet evident dat de rechter in de praktijk de overeenkomst daadwerkelijk nietig verklaart. Men zal eerder op zoek gaan naar oplossingen die de overeenkomst in stand houden, door bijvoorbeeld te aanvaarden dat de contractspartijen in de overeenkomst een impliciet wijzigingsrecht begrepen hebben of door in bepaalde gevallen een beroep te doen op het (restrictief te interpreteren) leerstuk van overmacht.

c. Overheidsverbintenis die indruist tegen het algemeen belang: situatie van overmacht of imprevisie?

86. Zelfs wanneer niet kan worden teruggevallen op een eenzijdig beëindigingsrecht, zal een overheid steeds van de uitvoering van een met het algemeen belang strijdige contractuele verbintenis kunnen afzien indien er sprake is van een situatie van overmacht. De imprevisieleer - hoewel in het Belgische recht niet aanvaard faciliteert dan weer de wijziging van de inhoud van de overeenkomst.

Mechelen, Kluwer, losbl., I96 e.v.; S. STIJNS, Verbintenissenrecht - Boek 1, Brugge, Die Keure, 2005, I02 e.v.

230 F. BELLEFLAMME, 'L'annulation de la décision d'attribution d'un contrat administratif et ses conséquences civiles', APT $2011,267$.

23I Brussel I8 december I997 CDPK I998, 33I; Brussel 25 maart I993, T.Aann. I993, 232.

232 Brussel 30 januari 200I, RW 2003-04, 505.

233 M. BOSMANS, 'De verhouding tussen het privé-contractenrecht en het publiek recht', RW I985-86, 2 II 8. 
87. Overmacht - beëindiging van de overeenkomst. Krachtens de artikelen II47 en II48 BW is een schuldenaar niet aansprakelijk wegens de niet-nakoming van een verbintenis wanneer deze niet-nakoming het gevolg is van een vreemde oorzaak of een situatie van overmacht. De heersende rechtspraak en rechtsleer beoordeelt het bestaan van overmacht op basis van de theorie van de ontoerekenbare onmogelijkheid. ${ }^{234}$ Dit impliceert dat er sprake dient te zijn van een onoverkomelijk beletsel dat niet aan de schuldenaar kan worden toegerekend.

Over de inhoud en de omvang van deze 'ontoerekenbare onmogelijkheid' bestaat discussie. Volgens de traditionele leer, die nog steeds in de meerderheid van de rechtspraak wordt gevolgd, dient de uitvoering van de verbintenis absoluut onmogelijk te zijn. ${ }^{235}$ In de rechtsleer, hierin gevolgd door een minderheid in de rechtspraak, wordt de laatste decennia genoegen genomen met een relatieve - menselijke - praktische onmogelijkheid. ${ }^{236}$

Men is het er wel over eens dat de aanwezigheid van een onoverkomelijk beletsel niet enkel beoordeeld mag worden in het licht van fysieke obstakels. De prestatie van een verbintenis kan ook verhinderd worden omwille van juridische motieven. ${ }^{237}$ De rechtspraak heeft zo meermaals overmacht aanvaard in het geval een overheidsbeslissing de uitvoering van een overeenkomst verbiedt ('le fait du Prince'). Het kan dan gaan om individuele overheidsbevelen, maar tevens om algemene overheidsmaatregelen. ${ }^{238}$ Met andere woorden: wanneer de uitvoering van de overeenkomst blijkt in te druisen tegen de geldende regelgeving en op die grond juridisch onmogelijk wordt, is er sprake van overmacht. ${ }^{239}$ Dit is in beginsel wel anders wanneer deze regelgeving uitgaat van (en dus toe te rekenen is aan) de contracterende overheid zelf. ${ }^{240}$

234 Cass. 9 december 1976, Arr.Cass. I977, 404; P. VAN OMMESLAGHE, Les obligations (vol. 2), Brussel, Bruylant, 2013, I426 e.v.

235 Antwerpen 26 februari 2007, RW 20I0-II, 574; Luik I6 november I987, JLMB I988, 808, noot P.H.; Rb. Brugge I8 december 2006, Rec.gén.enr.not. 2007, afl. 8, 296; Rb. Oudenaarde 27 november 2002, RW 2002-03, 228; Rb. Antwerpen I3 oktober I997, RW I999-2000, 264; Vred. 8 mei 2007, JT $2008, \mathrm{I} 62$.

236 Luik 8 november 1950, JL I950-5I, I29; Arbh. Luik 6 december I989, JTT I990, 256; Vred. MerbesleChâteau I7 maart I97I, JT I972, I23; P. VAN OMMESLAGHE, Les obligations (vol. 2), Brussel, Bruylant, 2013, I426; A. VAN OEVELEN, 'Overmacht en imprevisie in het Belgische contractenrecht', TPR 2008, 608 .

237 P. VAN OMMESLAGHE, 'Clauses de force majeure et d'imprévision dans les contrats internationaux', Rev. Dr. Intern. Et comp. I980, 29.

238 Zie bijv. Cass. I8 november I996, S.95.0roo.F; Brussel, 25 januari 2000, JT 2000, 790 (verbod van de Zaïrese overheid aan een overheidsbedrijf om de lonen van buitenlandse werknemers te indexeren); Brussel I3 juni I998, AJT I998-99, 895 (gemeente die weigert nog langer een overeenkomst uit te voeren waarbij zij zich ertoe had verbonden GFT-afval in kunststofzakken op te halen omdat het nieuwe Uitvoeringsplan Huishoudelijke afvalstoffen dit verbood); Kh. Antwerpen 28 april I989, TBH I990, 4I4.

239 Het feit dat de nakoming van een verbintenis praktisch gezien misschien nog wel mogelijk is, verandert hier niets aan. Zie L. SNAUWAERT en C. VAN DER ELST, 'Het onmogelijkheidscriterium inzake overmacht: hoe onmogelijk is onmogelijk?’, TPR $201 \mathrm{I}, \mathrm{I} 30$.

240 D. D'HOOGHE, 'Overeenkomsten met de overheid' in M. STORME, Y. MERCHIERS en J. HERBOTS (eds.), De overeenkomst vandaag en morgen, XXIe Postuniversitaire cyclus Delva, Antwerpen, Kluwer, I990, I62. 
De vraag die ons hier interesseert, is of er ook sprake kan zijn van een overmachtssituatie wanneer de omstandigheden voor de uitvoering van de overheidsovereenkomst sinds het moment van contractsluiting dermate veranderd zijn dat de uitoefening van de aangegane verbintenissen zou indruisen tegen het algemeen belang. In tegenstelling tot een klassieke situatie van fait du Prince, is het in dit geval niet de toepasselijke regelgeving die wordt herzien, maar zijn het wel degelijk de (feitelijke) omstandigheden - de behoeften van het algemeen belang - die omslaan. Het resultaat blijft evenwel hetzelfde. Zoals besproken, is de rechtsbekwaamheid van bestuurlijke overheden beperkt tot de handelingen die binnen het wettelijke doel - behartiging van het algemeen belang, of een onderdeel daarvan - ressorteren. Een bestuur dat buiten dit kader optreedt, maakt zich schuldig aan bevoegdheidsoverschrijding (zie nr. 9). Omwille van de gewijzigde omstandigheden zou de uitvoering van de overheidsovereenkomst inderdaad indruisen tegen de geldende regelgeving: het (van openbare orde zijnde) wettelijke specialiteitsbeginsel. ${ }^{24 \mathrm{I}}$ In die zin hebben we hier wel degelijk te maken met een onoverkomelijk beletsel. Het gevaar is echter niet denkbeeldig dat deze toepassing van de overmachtsleer een te ruime appreciatiemarge aan de overheid laat en aanleiding zou geven tot misbruik. Redelijkerwijze sluit niet elk motief van algemeen belang ook een situatie van overmacht in. Het lijkt in elk geval niet voldoende dat de uitvoering van een contractuele verbintenis de optimale behartiging van het publieke belang in de weg staat. Er zal moeten worden aangetoond dat deze verbintenis in concreto ook werkelijk indruist tegen het algemeen belang.

In geval van een betwisting zal telkens moeten worden vastgesteld of de overheid de overeenkomst ook onder de gewijzigde omstandigheden had kunnen aangaan. Wanneer dit duidelijk niet het geval is - en een dergelijke overeenkomst dus aangetast zou zijn met een nietigheidsgrond wegens afwezigheid van een oogmerk van algemeen belang (zie nrs. 79 e.v.) - kan er sprake zijn van overmacht. De drempel voor het aantonen van overmacht in geval van een wijziging in de behoeften van algemeen belang is dan ook hoog. Een louter negatieve impact op de financiële belangen van de overheidsrechtspersoon lijkt onvoldoende.

Of dit beletsel bovendien ontoerekenbaar is aan de overheid als schuldenaar (d.w.z. niet het gevolg is van een eigen fout, maar onvoorzienbaar bij het aangaan van het contract en bovendien onvermijdbaar), zal steeds afhangen van de concrete feitelijke context.

In geval van overmacht wordt de overheid van haar verbintenis bevrijd zonder dat hierbij een plaatsvervangende schadevergoeding dient te worden betaald. Deze bevrijding is ofwel tijdelijk - indien het beletsel van voorbijgaande aard is - waardoor de uitvoering van de verbintenis wordt opgeschort, ofwel definitief - voor zover het beletsel een blijvende hinderpaal vormt. Het lijkt erop dat we in de besproken hypo-

24I Het feit dat we hier, in tegenstelling tot in de rechtspraak aanvaarde gevallen van fait du Prince, te maken hebben met de overheid (de 'Prince') als contractspartij lijkt in deze van geen belang te zijn. Ook de overheid is immers onderworpen aan de rule of law. 
these, de gewijzigde omstandigheden van algemeen belang, veelal te maken zullen hebben met een blijvende hinderpaal.

Om geschillen te voorkomen kunnen de partijen in de overeenkomst preventief, al dan niet limitatief, de situaties aangeven die zij als overmacht kwalificeren. De bestuurlijke overheid zou aldus bepaalde omstandigheden kunnen laten opnemen die voor haar een wijziging van het algemeen belang impliceren en een situatie van overmacht uitmaken. Het is niet vereist dat deze omstandigheden ook werkelijk aan de gemeenrechtelijke toepassingsvoorwaarden voor overmacht beantwoorden. In dat geval is er in realiteit echter sprake van een verkapte exoneratieclausule, waarop de normale beperkingen van toepassing zijn. ${ }^{242}$

88. Imprevisie - wijziging van de overeenkomst. Op basis van overmacht kan een overheidsovereenkomst worden beëindigd, maar niet worden aangepast aan gewijzigde omstandigheden. Een rechtsfiguur die wel voorziet in de wijziging van een overeenkomst is de imprevisieleer. Er is sprake van imprevisie wanneer zich, na het moment van contractsluiting, abnormale en redelijkerwijs onvoorzienbare omstandigheden voordoen die niet toerekenbaar zijn aan een van de partijen, waarvan geen van de partijen het risico op zich heeft genomen en die het economische evenwicht of de structuur van de overeenkomst dermate verstoren dat de prestatie van de schuldenaar onredelijk wordt verzwaard. In zo'n geval kan een rechter het contract aanpassen aan de gewijzigde omstandigheden of ontbinden. In tegenstelling tot een situatie van overmacht wordt de prestatie van de schuldenaar dus niet onmogelijk, maar enkel (onredelijk) verzwaard. ${ }^{243}$

De imprevisieleer werd reeds geïncorporeerd in bepaalde specifieke wetten ${ }^{244}$ en wordt verdedigd door een deel van de rechtsleer, ${ }^{245}$ maar is tot op heden niet aanvaard als algemene rechtsfiguur. ${ }^{246}$ Niettemin werkt de logica van de imprevisieleer

242 A. VAN OEVELEN, 'Overmacht en imprevisie in het Belgische contractenrecht', TPR 2008, 6I5 e.v.; A. DRAULANS en J. RASQUIN, 'Overmachts-, imprevisie- en hardship-clausules' in E. TERRYN, A.-L. VERBEKE, H. DE DECKER et al. (eds.), Gemeenrechtelijke clausules, Antwerpen, Intersentia, 20I3, IIgI.

243 P. VAN OMMESLAGHE, Les obligations (vol. 2), Brussel, Bruylant, 20I3, 8II e.v.; A. VAN OEVELEN, 'Overmacht en imprevisie in het Belgische contractenrecht', TPR 2008, 622

244 Op grond van artikel 65 van het Koninklijk Besluit van I4 januari $20{ }_{3} 3$ tot bepaling van de algemene uitvoeringsregels van de overheidsopdrachten en van de concessies voor openbare werken kan de opdrachtnemer om een herziening of verbreking van de overeenkomst vragen wanneer hij een zeer belangrijk nadeel heeft geleden omwille van omstandigheden die hij redelijkerwijze niet kon voorzien, noch ontwijken en waarvan hij de gevolgen niet kon verhelpen. Zie ook P. VAN OMMESLAGHE, Les obligations (vol. 2), Brussel, Bruylant, 2013, 824 e.v., nrs. 538-539.

245 Zie voor een overzicht P. VAN OMMESLAGHE, Les obligations (vol. 2), Brussel, Bruylant, 2013, 823, nr. 537.

246 Het Hof van Cassatie oordeelde reeds meermaals dat wettig aangegane overeenkomsten de partijen tot wet strekken en in principe enkel kunnen worden herroepen met wederzijdse toestemming of op door de wet erkende gronden. De regel dat overeenkomsten te goeder trouw moeten worden uitgevoerd impliceert niet dat de schuldeiser, wanneer nieuwe en door de partijen bij het sluiten van de overeenkomst niet voorziene omstandigheden de uitvoering van de overeenkomst voor de schuldenaar bemoeilijken, de betaling van zijn schuldvordering niet kan vorderen. Zie Cass. 20 april 2006, C.03.0084.N; Cass. I4 april I994, Arr.Cass. I994, 369; Pas. 1994, I., 365; Cass. 7 februari I994, Arr. Cass. I994, I46; Pas. I994, I., I50. 
wel door in andere rechtsfiguren. Zo lijkt het Hof van Cassatie te aanvaarden dat een rechter een overeenkomst kan aanpassen wanneer, na een ingrijpende wijziging van het contractueel evenwicht, de vordering van een schuldeiser om onverminderd de verschuldigde prestatie uit te voeren rechtsmisbruik uitmaakt. ${ }^{247}$ Daarnaast wordt in de rechtsleer ook gewag gemaakt van het feit dat sommige rechtspraak de voorwaarden voor het aanvaarden van een 'onmogelijke uitvoering' in het kader van overmacht soepeler interpreteert. ${ }^{248}$

Ook hier geldt dat contractspartijen op voorhand een akkoord kunnen sluiten over de omstandigheden die volgens hen het contractuele evenwicht danig verstoren en aanleiding geven tot een heronderhandeling van de overeenkomst. ${ }^{249}$

89. Overigens verbaast het dat het potentieel van het overmachts- en imprevisieleerstuk niet ten volle wordt benut in situaties waarin nieuwe wetgevende of reglementaire initiatieven, die afwijken van reeds bestaande rechtskaders, invloed uitoefenen op de uitvoering van de overeenkomst. Zo wordt veelal aangenomen dat de wijzigingen aan de overeenkomst waartoe deze nieuwe initiatieven nopen, plaatsvinden op grond van het veranderlijkheidsbeginsel waardoor de overheid eenzijdig op de overeenkomst kan terugkomen. Hierbij wordt ervan uitgegaan dat de overheid steeds gehouden is de schade van de wederpartij volledig te vergoeden (vgl. nr. 54). In de rechtsleer wordt kritiek geuit op het feit dat het financiële risico van dergelijke initiatieven op deze manier steeds bij de overheid wordt gelegd. ${ }^{25}$ We lijken hier echter te maken te hebben met een klassieke toepassing van het 'fait du Prince'. Ook (gedecentraliseerde) overheden zijn immers gewoon onderworpen aan het wettigheids- en specialiteitsbeginsel (zie nrs. 8 e.v.). Voor zover de bestuurlijke overheid zelf geen vat heeft op de gewijzigde regelgeving, kan zij dergelijke initiatieven niet voorzien, net zomin als een particulier of private rechtspersoon. Dat de overheid haar contractuele verbintenis niet uitvoert, hoeft dus niet verantwoord te worden op grond van het principe van de veranderlijkheid van de openbare dienst, maar heeft alles te maken met een situatie van overmacht of imprevisie.

\subsection{Privaatrechtelijke remedies bij overheidsovereenkomsten en de continuïteit van de openbare dienst}

90. Privaatrechtelijke remedies kunnen invloed uitoefenen op de uitvoering van een overheidsovereenkomst. Zo resulteert de exeptio non adimpleti contractus (enac) in de

247 Cass. I4 oktober 20I0, C.o9.o608.F; Cass. 20 april 2006, C.03.0084.N; Cass. I4 april I994, Arr.Cass. I994, 369; Pas. I994, I., 365. Zie ook D. PHILIPPE, 'Le bouleversement de l'économie contractuelle en droit belge', RDIDC 20I5, afl. 2, I59.

248 S. VAN LOOCK, 'De imprevisieleer in België: Quousque tandem abutere patientia nostra?', TBBR 20I3, 450; S. STIJNS, Verbintenissenrecht - Boek 1, Brugge, Die Keure, 2005, I55.

249 A. VAN OEVELEN, 'Overmacht en imprevisie in het Belgische contractenrecht', TPR 2008, (603) 627 e.v.; A. DRAULANS en J. RASQUIN, 'Overmachts-, imprevisie- en hardship-clausules' in E. TERRYN, A.-L. VERBEKE, H. DE DECKER et al. (eds.), Gemeenrechtelijke clausules, Antwerpen, Intersentia, 20I3, IIgI.

250 K. LEUS, 'Overeenkomsten met de overheid of overheidsovereenkomsten: bijzondere overeenkomsten en algemeen belang' in R. FELTKAMP en E. JANSSENS (eds.), Ondernemingscontracten stap voor stap, Brussel, Larcier, 2013, 522 e.v. 
schorsing van de overeenkomst en wordt de overeenkomst retroactief tenietgedaan in geval van nietigheid of gerechtelijke ontbinding. Telkens wordt de continuïteit van de openbare dienst belemmerd, minstens bedreigd. De werking van deze rechtsfiguren is evenwel niet absoluut. Het gemeen recht voorziet immers steeds in een redelijkheidstoets waarbij de verschillende betrokken belangen tegen elkaar worden afgewogen. Ook het belang van de openbare dienst (het algemeen belang) kan hierbij in rekening worden gebracht. De marge om de toepassing van contractuele sancties te temperen is met andere woorden inherent aan het gemeen recht. De uitkomst zal hierbij dan ook doorgaans niet verschillen van de uitwerking van het publiekrechtelijke continuïteitsbeginsel. Hierna kijken we in de eerste plaats naar de nietigheid, als sanctie wegens schending van de geldigheidsvoorwaarden van een overeenkomst. Vervolgens wordt kort stilgestaan bij de algemene remedies - de uitvoering in natura en de uitvoering bij equivalent - waarna we nog ingaan op de bijkomende contractuele remedies in het kader van wederkerige contracten - de enac en de gerechtelijke ontbinding.

\section{a. Sanctionering in de precontractuele fase: de nietigheidsleer}

9I. De nietigheidssanctie mag niet verder reiken dan haar doel noodzakelijk maakt. ${ }^{251}$ In de meeste gevallen hoeft een onregelmatigheid in de totstandkoming dan ook niet per definitie te leiden tot de nietigheid van de overeenkomst. ${ }^{252}$ Zelfs wanneer er sprake zou zijn van een overtreding van een regel van openbare orde en dus een grond voor absolute nietigheid, die door de rechter ambtshalve moet worden opgeworpen, moet de overeenkomst niet automatisch worden vernietigd. ${ }^{253}$ De appreciatiemarge vindt de rechter in de theorie van het rechtsmisbruik. ${ }^{254}$

Een illustratie hiervan vinden we in een arrest van het Hof van Beroep te Luik van Io maart 2009, waarin uitspraak moest worden gedaan over de geldigheid van een overeenkomst tussen de stad Namen en de vennootschap City advertising tot uitbating van bushokjes met reclame. ${ }^{255}$ Een niet-geselecteerde inschrijver (J.C.Decaux) vorderde de nietigheid van de overeenkomst wegens schending van de

25I W. VAN GERVEN, Beginselen van Belgisch privaatrecht. 1: Algemeen deel, Antwerpen, Standaard, I973, 399 , nr. I27.

252 Cass. 26 mei 2006, C.05.0378.F. Dit is mogelijk anders wanneer de toepasselijke wet expliciet in de nietigheidssanctie voorziet. Zie F. PEERAER, 'De verhouding tussen openbare orde en dwingend recht sensu stricto in het Belgische verbintenissenrecht', TPR 2013, 2730, nr. 29; P. WERY, 'La nullité des contrats d'organisation de voyages et d'intermédiaire de voyages pour méconnaissance des formalités légales' (noot onder Cass. 26 mei 2006), TBBR 2007, 48I; M. VON KUEGELGEN, 'Réflexions sur le régime des nullités et des inopposabilités' in JEUNE BARREAU DE BRUXELLES (ed.), Les obligations contractuelles, Brussel, Jeune Barreau de Bruxelles, 2000, 608 .

253 F. PEERAER, ibid.

254 Cass. 22 september 2008, S.05.0I02.N: 'Misbruik van recht kan voorhanden zijn, ook al raakt het bedoelde recht de openbare orde of is het van dwingend recht'. Het Hof van Cassatie vindt de grondslag voor de theorie van het rechtsmisbruik in het principe van de goede trouw (artikel II34, $3^{\mathrm{e}}$ lid BW). Zie Cass. I9 september I983, Pas. I984, I, 55 .

255 Luik Io maart 2009, APT 20II, afl. 4, 444. 
overheidsopdrachtenregelgeving. Eerder had de Raad van State de toewijzingsbeslissing, als afsplitsbare rechtshandeling, reeds vernietigd. ${ }^{25} 6$

Waar de rechtbank van Namen in eerste aanleg nog had geoordeeld dat de overeenkomst absoluut nietig was, spreekt het Hof van Beroep zich hier niet over uit. Het Hof bepaalt enkel dat zelfs indien er inderdaad sprake zou zijn van een grond van absolute nietigheid, dit niet hoeft te resulteren in het tenietgaan van de overeenkomst. Het Hof haalde hier twee argumenten voor aan waarvan vooral het tweede ons op deze plaats interesseert: 'Le droit de réclamer la nullité de la convention qui se serait substituée à l'acte administratif nul ne serait pas absolu et pourrait être tempéré soit par les exigences du service public soit si le marché litigieux est exécuté ou quasi exécuté. In casu was de overeenkomst aangegaan voor een periode van 15 jaar, waarvan op het moment van de uitspraak reeds I 3 jaar was verlopen. Omdat de gevolgen van nietigheid enkel voor de toekomst zouden werken - het betrof een duurcontract van bepaalde duur - oordeelde het Hof dat 'la résilation [...] ne présentent par conséquent plus qu'un intérêt minime pour JC Decaux, sans commune mesure avec le trouble qu'elles causeraient sur la continuité du service public'. ${ }^{257}$

\section{b. Algemene remedies in geval van contractuele wanprestatie}

92. In geval van wanprestatie kan een contractspartij de gedwongen uitvoering van de toegezegde verbintenis vorderen, hetzij in natura, hetzij bij equivalent. ${ }^{258}$

De gedwongen uitvoering bij equivalent is in principe subsidiair ten aanzien van de uitvoering in natura. ${ }^{259}$ Dit is niet anders voor overheidsovereenkomsten. De scheiding der machten verzet zich er niet tegen dat een rechter de overheid, al dan niet onder verbeurte van een dwangsom, veroordeelt tot het uitvoeren van de toegezegde prestatie. ${ }^{260}$ Hiervoor kwam reeds aan bod dat een vordering tot rechtstreekse executie - zoals bijv. de gerechtelijke vervanging op grond van artikel II $44 \mathrm{BW}$ - wel strijdig kan zijn met het continuïteitsbeginsel (zie nr. 28). In plaats van een beroep te doen op het continuïteitsbeginsel kan weliswaar hetzelfde resultaat worden bereikt op basis van het gemeen recht. Een rechter kan de gedwongen uitvoering in natura immers steeds afwijzen wanneer er sprake is van rechtsmisbruik. ${ }^{26 \mathrm{I}}$ Ook hier is het duidelijk dat argumenten van algemeen belang een belangrijk element kunnen vormen in deze beoordeling. ${ }^{262}$

256 RvS 27 januari I999, nr. 78.378, SA J.C.DECAUX. Niet echt verrassend werd ook het hierop volgende gemeenteraadsbesluit dat de onregelmatigheid met retroactieve uitwerking trachtte te herstellen vernietigd. Zie RvS I4 november 2006, nr. I64.737, SA J.C.DECAUX.

257 Zie voor een omstandige bespreking F. BELLEFLAMME, 'L'annulation de la décision d'attribution d'un contrat administratif et ses conséquences civiles', APT 20II, 259.

258 S. STIJNS, Verbintenissenrecht - Boek 1, Brugge, Die Keure, 2005, I72 e.v.

259 Cass. I4 april 1994, Arr.Cass. I994, 374.

26o Cass. 26 juni i980, Arr.Cass. 1979-80, 1365.

26 I Cass. 30 januari 2003, C.00.0632.F.; Cass. 20 januari 1993, Arr.Cass. 1993, 74.

262 Cass. I4 februari I935, Pas. I935, I, I55. 
c. Bijkomende remedies in het kader van wederkerige overeenkomsten: exceptie van niet-uitvoering en gerechtelijke ontbinding

93. In een wederkerige overeenkomst beschikt een schuldeiser bij wanprestatie van de overheid over enkele bijkomende remedies. Deze remedies beïnvloeden de uitvoering van de overeenkomst (enac) of het bestaan van de overeenkomst (gerechtelijke ontbinding). Met het oog op de continuïteit van de openbare dienst wordt het recht van de schuldeiser om zich op deze rechtsfiguren te beroepen soms expliciet uitgesloten in een specifieke wettelijke of contractuele bepaling. ${ }^{263}$ In het andere geval moet rekening worden gehouden met de uitkomst van de inherente redelijkheidstoets die voortkomt uit de theorie van het rechtsmisbruik.

94. Op grond van de enac heeft een contractspartij het recht om de uitvoering van haar verbintenis te schorsen zolang de wederpartij haar verbintenis niet nakomt, noch aanbiedt deze na te komen. ${ }^{264}$ Deze exceptie geldt van rechtswege en gaat terug op de onderlinge verwevenheid en connexiteit van de verbintenissen in de wederkerige overeenkomst. In tegenstelling tot de gerechtelijke ontbinding is geen tussenkomst van de rechter vereist.

De schuldeiser dient steeds te goeder trouw te handelen. Dit impliceert in de eerste plaats dat er sprake dient te zijn van een zekere proportionaliteit tussen de tekortkoming van de schuldenaar (overheid) en het hieruit voortvloeiende nadeel voor de schuldeiser, enerzijds, en de nadelige gevolgen van de opschorting voor de schuldenaar anderzijds. ${ }^{265}$ Uit de schaarse relevante rechtspraak kan worden afgeleid dat hierbij aan het algemeen belang een bijzonder gewicht toekomt. Hoewel het Hof van Cassatie het bestaan van een algemeen rechtsbeginsel van voorrang van het algemeen belang op het particuliere belang ontkent, stelt sommige rechtspraak strengere eisen aan de toepassing van de enac wanneer deze exceptie meerdere personen treft. De enac zou dan enkel kunnen worden ingeroepen

263 J. LEBRUN en D. DEOM, 'L'exécution des créances contre les pouvoirs publics', JT i983, 264.

264 P. VAN OMMESLAGHE, Les obligations (vol. 1), Brussel, Bruylant, 2013, 872 e.v. Het Hof van Cassatie erkent het recht van een contractspartij om de enac in te roepen als een algemeen rechtsbeginsel. Zie Cass. I5 juni 2000, C.97.0118.N; Cass. 2I november 2003, C.01.0357.N.

265 Initieel werd de opschorting van de eigen contractuele verplichtingen slechts rechtmatig geacht in geval van een ernstige tekortkoming aan een hoofdverbintenis. In recentere rechtspraak wordt evenwel sneller aanvaard dat de enac principieel kan worden aangewend voor elke tekortkoming, zolang de opgeschorte prestatie niet meer schade toebrengt dan zelf werd ondervonden (bijv. Cass. 29 februari 2008, C.06.0303.F). Deze evolutie wordt toegeschreven aan het feit dat de objectieve trouw wordt uitgelegd in functie van de theorie van het rechtsmisbruik. Zie J. DE WEGGHELEIRE, 'De exceptio non adimpleti contractus' in X. (eds.), Bijzondere overeenkomsten. Artikelsgewijze commentaar met overzicht van rechtspraak en rechtsleer, Mechelen, Kluwer, losbl. I3-I4. Zie evenwel contra Rb. Brussel 28 februari 20I2, Res Jur.imm. 20I2, afl. 2, I27 ('manquement grave'). Sommige rechtsleer spreekt over het proportionaliteitsvereiste als objectieve goede trouw, te onderscheiden van het vereiste van subjectieve goede trouw, waarmee wordt gedoeld op het feit dat gedragingen van de excipiens niet zelf aan de basis mogen liggen van de tekortkoming van de wederpartij. Zie bijv. S. STIJNS, Verbintenissenrecht - Boek 1, Brugge, Die Keure, $2005,210$. 
als een laatste redmiddel. ${ }^{266}$ Of een negatieve impact op de continuïteit van een openbare dienst op zich echter voldoende is om gewag te kunnen maken van een disproportionele toepassing van de enac, blijft bij afwezigheid van rechtspraak ter zake onzeker.

95. Op grond van artikel II84 BW heeft een schuldeiser in een wederkerige overeenkomst bij wanprestatie van zijn schuldenaar de keuze om ofwel de schuldenaar te noodzaken zijn verbintenis uit te voeren (wanneer de uitvoering nog mogelijk is), ofwel de ontbinding van de overeenkomst te vorderen, met schadevergoeding. Met de ontbinding van een overeenkomst wordt een schuldeiser definitief van zijn verbintenis bevrijd. Tenzij in de overeenkomst een uitdrukkelijk ontbindend beding wordt opgenomen, gaat de ontbinding niet van rechtswege in maar dient zij te worden uitgesproken door de rechter. Volgens vaste cassatierechtspraak heeft een rechter de bevoegdheid om de opportuniteit van een vordering tot ontbinding te toetsen. Meer bepaald moet hij nagaan of de tekortkoming voldoende zwaarwichtig is om de gerechtelijke ontbinding te kunnen rechtvaardigen. ${ }^{267}$ Ook hier zou de vordering tot ontbinding dus kunnen worden afgewezen omwille van de onevenredig nadelige gevolgen voor het algemeen belang.

\subsection{Tegenstelbaarheid van de overeenkomst ten aanzien van derden}

96. De verhouding tussen de overeenkomst en derden laat zich analyseren aan de hand van het onderscheid tussen de interne en de externe gevolgen van de overeenkomst. ${ }^{268}$ Conform het beginsel van de relativiteit van overeenkomsten (artikel II65 BW) doet een overeenkomst enkel rechten en verplichtingen - interne gevolgen - ontstaan tussen de contracterende partijen (inter partes). Het bestaan van de overeenkomst als rechtsfeit - externe gevolgen - is echter wel steeds tegenstelbaar aan derden, die hiervan ook de gevolgen moeten ondergaan. ${ }^{269}$

Zo kan een overheidsovereenkomst een onmiskenbare invloed uitoefenen op de particuliere belangen van derden - als te onderscheiden van het door de overheid behartigde algemeen belang - evenwel zonder dat zij hier noodzakelijk ook rechten uit kunnen putten, en in principe ook zonder dat zij de (inhoud van de) overeenkomst kunnen aanvechten. ${ }^{270}$ Dit is bij uitstek problematisch bij de overeenkomsten

266 Zo overwoog de vrederechter van Sint-Jans-Molenbeek in een zaak van appartementsmede-eigendom dat 'l'intérêt collectif doit être privilégié par rapport à l'intérêt individuel'. Even later lezen we: 'Compte tenu de la primauté de l'intérêt collectif l'exception d'inexécution ne saurait être appliquée qu'avec beaucoup circonspection' (Vred. Sint-Jans-Molenbeek 2I februari 2006, T.App. 2006, 44). Wat voor een collectief belang geldt, lijkt a fortiori ook voor het algemeen belang te moeten gelden.

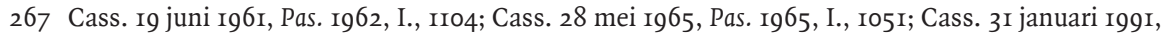
Arr.Cass. I990-9I, 584. Zie ook P. VAN OMMESLAGHE, Les obligations (vol. 1), Brussel, Bruylant, 2013, 909, nr. 589 e.v.; S. STIJNS, Verbintenissenrecht-Boek 1, Brugge, Die Keure, 2005, I93.

268 P. VAN OMMESLAGHE, Les obligations (vol. 1), Brussel, Bruylant, 2013, 645.

269 Cass. 27 mei I909, Pas. I909, I., 272.

270 Derden kunnen zich wel tegen het bestaan van een overeenkomst verzetten op grond van de actio pauliana (artikel II67 BW) en wanneer er sprake is van derde-medeplichtigheid aan andermans contractbreuk. Zie S. STIJNS, Verbintenissenrecht-Boek 1, Brugge, Die Keure, 2005, 223 e.v. 
die de organisatie van een openbare dienst tot voorwerp hebben. De gebruikers van deze dienst ondervinden wel de gevolgen van de gemaakte afspraken, maar kunnen de overeenkomst niet in rechte afdwingen of zich ertegen verzetten.

Het privaatrecht kent wel rechtsfiguren die de relativiteit van de interne gevolgen van een overeenkomst in belangrijke mate relativeren, maar deze zijn in deze context niet dienstig. Zo kan een derde als schuldeiser een eigen recht verwerven uit de overeenkomst wanneer een contractspartij zich hier ten aanzien van de wederpartij toe verbindt in een beding ten behoeve van een derde (artikel II2I BW). Dit veronderstelt echter dat de contractspartijen ook de duidelijke bedoeling hebben om de derde een eigen (in rechte afdwingbaar) recht te gunnen. ${ }^{271}$ Deze bedoeling is in de context van overheidsovereenkomsten veelal niet aanwezig.

Waar uit voorgaande analyse blijkt dat het privaatrecht ruimte laat voor de incorporatie en de behartiging van het algemeen belang, geldt hetzelfde niet voor de particuliere belangen van derden. Hiermee verschilt de contractuele verhouding fundamenteel van de reglementaire verhouding, waar het uitgangspunt juist de volledige derdenwerking is, wat resulteert in een hogere rechtsbescherming. Een reglement ressorteert rechtsgevolgen erga omnes waardoor een schending door iedere belanghebbende kan worden aangevochten, zowel voor de Raad van State (artikel I4 RvSwet en artikel I59 Gw.) als de gewone rechter (artikel I59 Gw.). In dit verband hoeft het niet te verwonderen dat beheersovereenkomsten door de rechtspraak vaak geherkwalificeerd worden als reglement (zie nr. 6o).

\subsection{Goede trouw als hefboom voor de beginselen van behoorlijk bestuur in de uitvoering van de overeenkomst}

97. Op grond van artikel II34, lid 3 BW dient elke contractspartij haar verbintenissen te goeder trouw uit te voeren. Naast een kader voor de interpretatie van overeenkomsten (interpretatieve functie) geldt het principe van de goede trouw in de uitvoering van de overeenkomst tevens als een gedragsregel met een aanvullende en een matigende functie. Op grond van de aanvullende functie van de goede trouw verbindt een overeenkomst niet enkel tot wat hier expliciet in overeen werd gekomen, maar tevens tot alle gevolgen die door de billijkheid aan de verbintenis worden toegekend (zie ook artikel II 35 BW). Volgens de matigende/beperkende functie is het een contractspartij verboden om de uit een overeenkomst voortvloeiende rechten aan te wenden op een wijze die kennelijk de grenzen van een normale uitoefening te buiten gaat (verbod van rechtsmisbruik). ${ }^{272}$

98. De verplichtingen die uit deze gedragsregels voortvloeien - de invulling van de noties 'billijkheid' en 'normale uitoefening' - worden bepaald en geconcretiseerd aan de hand van het criterium van de redelijke en billijke contractant die zich in

\footnotetext{
27 I P. VAN OMMESLAGHE, Les obligations (vol. 1), Brussel, Bruylant, 20I3, 686; S. STIJNS, Verbintenissenrecht-Boek 1, Brugge, Die Keure, 2005, 243.

272 P. VAN OMMESLAGHE, Les obligations (vol. 1), Brussel, Bruylant, 2013, I93 e.v.
} 
dezelfde omstandigheden weet geplaatst. Er dient met andere woorden rekening te worden gehouden met o.m. de aard van de overeenkomst, de intensiteit van de contractuele band en, in dit kader van bijzonder belang, de specifieke hoedanigheid van de contracterende partijen. ${ }^{273}$ Het lijkt dan ook vanzelfsprekend dat aan een overheid in dit verband hogere eisen kunnen worden gesteld, eisen die o.m. worden ingevuld door toepassing van de beginselen van behoorlijk bestuur.

99. De Nederlandse Hoge Raad gaat een stap verder en aanvaardde reeds expliciet in 1978 , in het standaardarrest Amsterdam v. Ikon, dat een overheid ook bij het uitoefenen van bevoegdheden uit privaatrechtelijke overeenkomsten beginselen van behoorlijk bestuur in acht dient te nemen. De Hoge Raad verzette zich hiermee tegen de lezing als zouden deze beginselen slechts elementen vormen in een aan de overheid meer ruimte latende algemene redelijkheidstoetsing, waardoor deze beginselen een zwakkere werking zouden hebben dan in het bestuursrecht. Aldus maakt de Hoge Raad toepassing van de gemengde leer, waarbij een zelfde rechtsverhouding gelijktijdig door privaat- en publiekrechtelijke regels wordt beheerst. ${ }^{274}$ De (schaarse) Belgische rechtspraak laat zich moeilijker interpreteren. Niettemin is er rechtspraak die de relatie tussen de goedetrouwnorm en de beginselen van behoorlijk bestuur aantoont, doch zonder dat hierbij steeds duidelijk wordt of de goedetrouwnorm ten aanzien van overheidsoptreden op deze basis ook effectief strenger moet worden ingevuld.

Ioo. In een arrest van 26 april 1996 sprak het Arbeidshof te Brussel zich uit over een vordering van de Vlaamse Gemeenschap tegen een personeelslid van een vrije hogeschool tot terugbetaling van te veel betaald loon. Aanleiding was het feit dat de Vlaamse Gemeenschap dit personeelslid - tewerkgesteld met een overeenkomst jarenlang een hogere wedde had uitbetaald dan werd voorzien in de bij Koninklijk Besluit vastgestelde formele weddeschalen. Het Arbeidshof oordeelde echter dat de Vlaamse Gemeenschap en de vrije onderwijsinstelling hun recht op terugvordering hadden verwerkt, en dit op basis van twee motieven. In de eerste plaats werd de Vlaamse Gemeenschap een schending van het vertrouwens- en het rechtszekerheidsbeginsel verweten. Op grond van deze beginselen van behoorlijk bestuur moeten door de overheid opgewekte gerechtvaardigde verwachtingen van de burger in beginsel worden gehonoreerd. Daarnaast oordeelde het Hof dat de verplichting om een overeenkomst te goeder trouw uit te voeren (artikel II 34 lid 3 BW) eraan in de weg staat dat een schuldeiser zijn rechten opeist wanneer hij door zijn eigen schuldige nalatigheid de schuld onrechtmatig heeft doen aangroeien. ${ }^{275}$ Het Arbeidshof

273 Kh. Tongeren I6 november 20I3, DAOR 20I4, afl. I09, I02; Luik I8 juni 20I2, 20II/RG/854, www. juridat.com.

274 Hoge Raad 27 maart I987, nr. I2.807, Amsterdam v. Ikon. Een aanzet voor deze leer kon reeds worden gevonden in het wetsvoorstel voor het Nieuw Burgerlijk Wetboek - zie het huidige artikel 3:I4 NBW. Later werd de gemengde leer ook ingeschreven in artikel 3:I lid 2 van de Algemene wet bestuursrecht.

275 Het feit dat de rechter de overheid een schending van de goede trouw in de uitvoering van de overeenkomst verwijt, doet in eerste instantie vreemd aan. Er bestaat immers geen overeenkomst tussen de overheid en de onderwijzer, enkel tussen de vrije onderwijsinstelling en de onderwijzer. Anderzijds is het wel de overheid die de wedden van de onderwijzers rechtstreeks aan de leden van het 
verwijst echter nergens naar een rechtstreeks causaal verband tussen de schending van het vertrouwensbeginsel en de schending van de goede trouw. De goede trouw werd dus niet miskend geacht omdat het vertrouwensbeginsel werd geschonden. ${ }^{276}$

IOI. De doorwerking van de beginselen van behoorlijk bestuur in gemeenrechtelijke rechtsfiguren is meer uitgesproken in de context van de uitvoering en de beëindiging van arbeidsovereenkomsten. Waar een significant deel van de arbeidsrechters niet meegaat in het verhaal van een rechtstreekse doorwerking, lijkt er meer eensgezindheid over het feit dat bepaalde open normen uitgelegd kunnen worden in functie van de beginselen van behoorlijk bestuur. Het gaat dan bijvoorbeeld om de noties 'willekeurige afdanking' (artikel 63 Arbeidsovereenkomstenwet) of misbruik van ontslagrecht. ${ }^{277}$ In een arrest van 27 maart 2009 overwoog het Arbeidshof te Bergen dat een ontslagbeslissing van een gemeentelijke overheid op zich willekeurig was omdat deze beslissing niet gemotiveerd was en niet vooraf werd gegaan door een hoorzitting. ${ }^{278}$ Het is echter vaste rechtspraak van het Hof van Cassatie dat een rechter bij het beoordelen van het willekeurige karakter van een ontslag ook rekening mag houden met argumenten die de overheid aanbrengt in het kader van de geschilprocedure en dus nadat de ontslagbeslissing aan de werknemer ter kennis werd gebracht. ${ }^{279} \mathrm{De}$ overheid wordt met andere woorden op basis van het gemeen recht aan specifieke (strengere) standaarden onderworpen door middel van de doorwerking van de formele motiveringsplicht in de open norm van willekeurige afdanking. ${ }^{280}$

\section{$6 \quad$ Epiloog}

\section{I Een verschillend beoordelingskader, maar vergelijkbare uitkomst: convergentie tussen het publiek- en het privaatrecht}

I02. De in het vorige hoofdstuk besproken hechte relatie tussen de beginselen van behoorlijk bestuur en het vereiste van goede trouw mag niet verbazen. Beide

onderwijzend personeel betaalt (artikel 36, \$2 Wet 29 mei I959). De rechtspraak aanvaardt hierbij dat het personeelslid een rechtstreekse vordering ten aanzien van de overheid heeft. Tegelijkertijd beschikt de overheid over een rechtstreekse vordering jegens het personeel voor terugbetaling van de te veel betaalde sommen. Zie D. LINDEMANS, 'De bevoegde rechter inzake terugvordering van beweerd onterecht betaalde wedde van een bij arbeidsovereenkomst aangeworven leerkracht' (noot onder Antwerpen I5 maart 2005), P\&B 2006, 6I.

276 Het vertrouwens- en het rechtszekerheidsbeginsel gelden ook als privaatrechtelijke beginselen en liggen dus aan de gehele rechtsorde ten grondslag. Niettemin past het Hof deze beginselen in casu expliciet toe als beginselen van behoorlijk bestuur.

277 D. CUYPERS, 'Beginselen van behoorlijk bestuur in personeelsmateries: zowel voor ambtenaren als voor overheidscontractanten' in R. JANVIER en A. DE BECKER (eds.), De rechtspositie van het overheidspersoneel in beweging, Brugge, die Keure, 20I4, 24.

278 Arbh. Bergen 27 maart 2009, JTT 2010, I07.

279 Cass. I5 juni i988, Pas. I988, I, I230.

280 Zie ook Arbh. Bergen 21 november 20I2, JLMB 2013, I227; Soc.Kron. 20I3, 38I; Arbh. Bergen I3 september 20II, Soc.Kron. 2013, 390; Arbh. Bergen 6 september 2010, JTT 20II, I03; Arbh. Brussel 30 mei 2006, Soc.Kron. 2007, 522, noot D. CUYPERS. Zie evenwel contra: L. DEAR, 'L'audition préalable et la motivation du congé' in C.-E. CLESSE en S. GILSON (eds.), Le licenciement abusif: notions, évolutions, questions spéciales, Louvain-la-Neuve, Anthemis, 2009, II2. 
rechtsnormen geven immers uitdrukking aan - en concretiseren zo - het algemene rechtsbeginsel van behoorlijk handelen. ${ }^{281}$ Dezelfde conclusie dringt zich op bij de toetsing aan de zorgvuldigheidsnorm in de zin van artikel $\mathrm{I}_{3} 82 \mathrm{BW}$. De gemeenschappelijke rechtsbasis heeft tot gevolg dat het resultaat van de toepassing van deze privaat- en publiekrechtelijke normen vaak hetzelfde, of in elk geval sterk vergelijkbaar is.

Daarenboven is de rechtspraak bij het concreet vormgeven van deze normen bereid om over het muurtje te kijken. Dit komt duidelijk naar voren in de rechtspraak met betrekking tot exoneratiebedingen in overheidsovereenkomsten. Reglementaire exoneratiebedingen worden getoetst aan de beginselen van de openbare dienst en de beginselen van behoorlijk bestuur, in het bijzonder het redelijkheidsbeginsel. Voor contractuele exoneratiebedingen is het vaste rechtspraak dat een dergelijk beding niet iedere zin en betekenis aan de overeenkomst mag ontnemen. ${ }^{282}$ Hoewel het op het eerste gezicht over twee verschillende beoordelingskaders gaat, oordeelde een vrederechter aangaande de geoorloofdheid van een reglementair exoneratiebeding in een overeenkomst tussen een nutsbedrijf en zijn gebruiker dat 'de maatstaven die hiervoor dan gehanteerd moeten worden [...] het best vergelijkbaar [zijn] met die welke in het algemene contractenrecht worden toegepast'. De rechter overwoog verder met betrekking tot de beginselen van behoorlijk bestuur en de beginselen van openbare dienst dat 'deze twee toetsingsgronden kunnen worden beschouwd als de publiekrechtelijke tegenhanger van het in het algemeen contractenrecht geldend criterium dat een exoneratiebeding, om geoorloofd te zijn, niet iedere zin of betekenis mag ontnemen aan het door de partijen beoogde contract. Zodoende zou men dus kunnen besluiten tot een ongeoorloofdheid van zulke exoneratieclausule als dit het voorwerp van de prestatie of de tot de openbare dienst behorende taak uitholt,' Om de cirkel te sluiten werd tot slot opgemerkt dat de kern van de openbare dienst die aan de openbare nutsbedrijven is toevertrouwd nu juist (mede) wordt bepaald door het beginsel van de continuïteit van de openbare dienst en de naleving van de beginselen van behoorlijk bestuur. ${ }^{283}$

28I Zie hierover: W. VAN GERVEN, 'Beginselen van behoorlijk handelen', RW I982-83. 966, e.v. Het Hof van Beroep te Luik oordeelde in dit verband dat 'l'obligation d'agir de bonne foi dépasse les domaines contractuels et précontractuels; qu'il s'agit d'une règle de bon comportement qui s'impose à tous, d'un véritable principe général de droit' (Luik 9 oktober I99I, JT I992, I30).

282 Cass. 27 september I990, Arr.Cass. I990-9I, 88; Cass. 23 november 1987, Arr.Cass. 1987-88, 37I. De grondslag van deze regel moet waarschijnlijk worden gevonden in het vereiste van goede trouw. Zie P. VAN OMMESLAGHE, Les obligations (vol. 2), Brussel, Bruylant, 20I3, I7I4, nr. II62. Daarnaast kan een exoneratiebeding niet ingaan tegen een specifieke wettelijke bepaling van dwingend recht of openbare orde (zie voor consumenten artikel VI.83., I $3^{\circ}$ Wetboek economisch recht + artikel Io Wet Productaansprakelijkheid) of een contractspartij ontslaan van aansprakelijkheid wegens eigen bedrog. Zie daarover K.-J. VANDORMAEL, 'De rechtsverhouding tussen openbare diensten en gebruikers: van reglementaire of contractuele aard? (noot bij Rb. Limburg I9 december 20I4)', Limb. Rechtsl. 2015, 203.

283 Zie Vred. Antwerpen, 9 februari 20Io, T.Vred. 20I2, 333-334. Zie ook Gent I9 december 2008, T.Not. 20I0, afl. 3, II7; Antwerpen 7 juni I999, RW 2000-oI, 51. Zie ook K.-J. VANDORMAEL, 'De rechtsverhouding tussen openbare diensten en gebruikers: van reglementaire of contractuele aard?' (noot bij Rb. Limburg, I9 december 20I4), Limb. Rechtsl. 2015, 286. 
I03. De convergentie die optreedt tussen het publiek- en het privaatrecht geeft overigens aanleiding tot 'crossover-rechtspraak'. Dit wordt duidelijk in een arrest van het Hof van Beroep te Antwerpen van 7 juni I999. ${ }^{284}$ In dit arrest, waarin uitspraak werd gedaan over de geldigheid van een in een havenreglement opgenomen exoneratiebeding dat de stad Antwerpen ontsloeg van verantwoordelijkheid voor alle schade veroorzaakt bij het slepen van boten, ongeacht de oorzaak van de schade, oordeelde het Hof dat dit beding door zijn onbeperkte algemeenheid onredelijk bezwarend was en derhalve strijdig was met "de "goede trouw regel" van behoorlijk bestuur'. Het Hof besloot hiertoe na een belangenafweging waarbij het overwoog 'dat het loutere feit dat de sleepoperatie tot voordeel strekt van het gesleepte schip, terwijl de overheidsdienst enkel het gemeenschappelijke belang nastreeft, geen algemene immuniteit verantwoordt'.

Het valt overigens op dat in dit arrest nergens expliciet wordt overgegaan tot de kwalificatie van de verhouding tussen de stad Antwerpen (hierin opgevolgd door het Gemeentelijk Autonoom Havenbedrijf) en de gebruiker van de sleepdienst. Hoewel het Hof vaststelt dat het exoneratiebeding opgenomen was in een reglement, de 'Tariefverordening', benadert het de rechtsverhouding tegelijkertijd als een (standaard) overeenkomst wanneer het overweegt dat de geldigheid van dergelijk beding getoetst dient te worden aan het vereiste van uitdrukkelijke toestemming door de gebruiker. Gevolg van deze (weliswaar foutieve) redenering is dat in dit arrest een overheidsovereenkomst onderworpen wordt aan de beginselen van behoorlijk bestuur. Hoe het ook zij, deze rechtspraak lijkt de inwisselbaarheid van de goedetrouwnorm en de beginselen van behoorlijk bestuur als een evidentie op te vatten. Het uitdenken van een theoretisch kader lijkt voor de praktijk dan ook van minder belang. Tekenend is de bedenking van het Hof dat 'de vraag naar de verhouding tussen gedingpartijen van contractuele of van reglementaire aard is, van minder belang is'.

I04. De aanwending van het privaatrecht bij het vormgeven van het overheidsbeleid is uiteraard niet beperkt tot het contractuele overheidsoptreden. In de praktijk rijst van tijd tot tijd de vraag of een overheid bij de handhaving van publieke regelgeving gebruik kan maken van het (buitencontractuele) aansprakelijkheidsrecht. Een vergelijking met Nederland maakt duidelijk dat ook het antwoord op deze vraag niet noodzakelijk hoeft te verschillen naar gelang een publiek- dan wel privaatrechtelijke benadering wordt gehanteerd.

Naar Belgisch recht wordt een aansprakelijkheidsvordering van de overheid afgewezen wanneer uit de inhoud of de strekking van een overeenkomst, wet of reglement blijkt dat de geleden schade of de verrichte uitgave definitief voor haar rekening

284 Antwerpen 7 juni 1999, RW 2000-oI, 5I. Zie ook de noten hierbij: A. DE BOECK, 'De toetsing van de geldigheid van de in havenreglementen opgenomen bevrijdingsbedingen aan de beginselen van behoorlijk bestuur', RW 2000-OI, 54 en E. VAN HOOYDONK, 'Het onderscheid tussen havendiensten in het mededingingsrecht', AJT 2000-oI, 7. Het betreft hier vaste rechtspraak van het Hof van Beroep te Antwerpen, zie tevens Antwerpen I2 oktober 1998, Eur.Vervoerr. 1998, 8II en Antwerpen 7 juni I989, AR 173/86, Aegis Eland, onuitgegeven. 
moet blijven. ${ }^{285}$ Het Hof van Cassatie sluit in dat geval het bestaan van vergoedbare schade uit. ${ }^{286}$ In toepassing van deze schadeleer sprak het Hof van Beroep te Antwerpen zich in een arrest van 25 oktober 20 II uit over een vordering tot schadevergoeding van de stad Antwerpen wegens interventiekosten van de brandweer jegens de schadeverwekker die strafrechtelijk veroordeeld was op grond van o.a. poging tot vernieling door ontploffing. Uit het toepasselijke wettelijke kader leidde het Hof af dat de wetgever de kosten verbonden aan een interventie binnen de wettelijke opdracht definitief ten laste van de overheid legt. Deze kosten maakten dan ook geen vergoedbare schade uit. ${ }^{287}$ Hoewel de redenering verschilt, komt de Nederlandse Hoge Raad tot hetzelfde resultaat in het Brandweerkostenarrest van II december I992. De Hoge Raad wees de privaatrechtelijke vordering van de gemeente Vlissingen wegens nablussings- en bewakingswerkzaamheden na een brand op een schip af op grond van de doorkruisingsleer. De afwezigheid van een publiekrechtelijke regeling verraadde aldus het Hof de wil van de wetgever om de mogelijkheid van verhaal van de kosten uit te sluiten. Een vordering op privaatrechtelijke leest zou bijgevolg de publiekrechtelijke regeling op onaanvaardbare wijze doorkruisen. ${ }^{288}$

Hoewel rechtscolleges in België en Nederland dus vanuit een verschillend rechtskader redeneren - respectievelijk de privaatrechtelijke schadeleer (voorheen causaliteitsleer) en de publiekrechtelijke doorkruisingsleer - zien we dat de achterliggende logica en de aangedragen oplossing vaak dezelfde zijn. Aan de basis van de uitsluiting van het verhaalsrecht voor brandweerkosten ligt zo de overtuiging dat bepaalde risico's dienen te worden gesocialiseerd, in dit geval om te vermijden dat een financiële drempel burgers zou weerhouden om tot alarmering over te gaan.

\subsection{Privaat- en publiekrecht: yin en yang in het overheidscontractenrecht}

I05. De tweewegenleer mag in België dan wel een oud leerstuk zijn, het is relatief onontgonnen. Terwijl de Nederlandse doorkruisingsleer gedurende de jaren

285 Cass. I9 februari 200I, C.99.00I4.N; C.99.0183.N; C.99.0228.N; C.00.0242.N; Cass. 20 februari 200I, P.98.1629.N. Zie ook: Cass. I8 september 2007, P.07.0005.N; B. WEYTS en T. VANSWEEVELT, Handboek buitencontractueel aansprakelijkheidsrecht, Antwerpen, Intersentia, 2009, 852 e.v.; M. VAN QUICKENBORNE, 'Overzicht van rechtspraak. Aansprakelijkheid uit onrechtmatige daad. Oorzakelijk verband', TPR 20I0, 348 e.v.

286 Voor de cassatiearresten van ig februari 200I benaderde het Hof van Cassatie deze problematiek vanuit de causaliteitsleer. Zo werd de aanwezigheid van een contractuele of wettelijke verplichting door het Hof van Cassatie uitgelegd als een autonome juridische oorzaak die het oorzakelijk verband tussen de fout en de schade verbrak (Cass. 28 april I978, Arr.Cass. I978, I004, concl. F. DUMON). Het Hof voorzag wel een uitzondering wanneer de verplichting secundair was ten opzichte van de op de dader van een (oneigenlijk) misdrijf rustende verplichting om een door zijn toedoen ontstane toestand die niet mag blijven voortduren, te doen ophouden. Zie Cass. I3 april I988, Arr. Cass. I987-88, I020. Zie bijv. over de onmogelijkheid voor de fiscus om een wegens fraude niet tijdig ingekohierde belastingsschuld te recupereren door middel van een aansprakelijkheidsvordering (Cass. 8 september I999, P.99.0360.F; zie ook de noot hierbij van M. VAN QUICKENBORNE, 'Verlies van de mogelijkheid tot inkohieren, burgerlijke partijstelling door de fiscus, en doorbreking van het oorzakelijk verband door het ingrijpen van een eigen juridische oorzaak', R.Cass. 200o, 225).

287 Antwerpen 25 oktober 20II, RW 20I2-I3, afl. 25, 99I.

288 Hoge Raad II december I992, AB I993, nr. 30I, noot G.A. VAN DER VEEN. 
verder is vormgegeven en aangescherpt in de rechtspraak en de rechtsleer, is de rechtspraak in België erg schaars en ontbreekt algemene theorievorming. Een reden hiervoor kan worden gevonden in de diffuse rechtsmachtverdeling, waarbij zowel de gewone rechter als de administratieve rechter elk binnen hun eigen bevoegdheid en finaliteit hun stempel drukken. Dat de gewone rechter bij uitsluiting bevoegd is om uitspraak te doen over contractuele geschillen, verhindert niet dat de bestuursrechter bevoegd is om de wettigheid te toetsen van hiervan afsplitsbare bestuurshandelingen. Beide rechtscolleges maken hierbij gebruik van een eigen gereedschapskist, die niet toevallig meer of minder aanleunt bij het privaat- of het publiekrecht. Dit verklaart wellicht waarom de vraag of het de overheid (binnen de bij uitstek publiekrechtelijke contouren) is toegestaan om te contracteren weinig aandacht krijgt in de rechtspraak van de gewone rechter. De discussie verplaatst zich veeleer meteen naar de vraag welk recht de contractuele verhouding beheerst. Ook hierbij maakt de gewone rechter bij uitstek toepassing van het privaatrecht. Zeker wanneer het gaat om het vrijwaren van de behoeften van een openbare dienst grijpen de rechtspraak en de rechtsleer echter dankbaar terug naar de beginselen van openbare dienst en de beginselen van behoorlijk bestuur. Vooral de vraag of deze beginselen rechtstreeks dan wel onrechtstreeks doorwerken in de contractuele verhouding blijft de geesten beroeren. Deze klif wordt vaak omzeild door de rechtsverhouding op zijn minst deels als reglementair (en dus niet als contractueel) te kwalificeren. In beide gevallen komt deze rechtspraak erg ad hoc en vaak erg welwillend tot stand. In elk geval spreekt hieruit een wantrouwen ten aanzien van het privaatrecht en hoe dit het algemeen belang kan behartigen. Uit de analyse in dit preadvies blijkt dat dit wantrouwen niet steeds gerechtvaardigd is, maar dat de overheid het privaatrecht vaak te ondoordacht inzet.

I06. Omdat vaststaat dat eenzelfde verhouding naar Belgisch recht gelijktijdig kan worden beheerst door privaat- en publiekrechtelijke regels, is de discussie naar de verhouding tussen beide rechtstakken nooit echtgeluwd. ${ }^{289}$ Hoewel het Nederlandse recht de inspiratiebron vormt voor de Belgische tweewegenleer, kent het bestuursrecht in Nederland een ruimere autonomie. De Nederlandse codificatie van het bestuursrecht in de Algemene wet bestuursrecht heeft deze evolutie onmiskenbaar versterkt. Ook voordien waren er echter al duidelijke signalen in die richting. De Hoge Raad erkent reeds sinds het standaardarrest Amsterdam v. Ikon van 27 maart I987 dat het toepassingsgebied van de beginselen van behoorlijk bestuur zich uitstrekt tot het privaatrechtelijke optreden van de overheid. ${ }^{290}$

I07. Naar Belgisch recht is de rechtstreekse doorwerking van het publiekrecht in contractuele overheidsverhoudingen veel minder vanzelfsprekend. Gelet op het privaatrechtelijke uitgangspunt leunt het Belgische recht dichter aan bij de gemene

289 S. LIERMAN, Besturen zonder grenzen. Over grijze zones en blinde vlekken, Acta Falconis VIII, Antwerpen, Intersentia, 2015, 27.

290 Hoge Raad 27 maart I987, AB I987, 273 (Amsterdam/Ikon); Hoge Raad 24 april I992, AB I992, 542; NJ 1993, 232 (Zeeland/Hoondert). Deze rechtspraak is inmiddels verankerd in het Nederlandse Burgerlijk Wetboek (artikel 3:I4) en de Algemene Wet Bestuursrecht (artikel 3:2). 
leer en gelden publiekrechtelijke regels slechts bij uitzondering. ${ }^{291}$ Dat de gemengde rechtsleer in België minder voet aan de grond krijgt dan in Nederland, heeft uiteraard opnieuw veel, zo niet alles te maken met de rechtsmachtverdeling tussen de gewone en de administratieve rechter. Ook in eigen land kan echter in uitzonderlijke gevallen een gelijksoortig geluid worden waargenomen. ${ }^{292}$ Zo pleitte P. Goffaux er in zijn proefschrift voor om het bestuursrecht als een autonoom systeem te beschouwen van waaruit oplossingen kunnen worden aangereikt voor de verhouding van en met de overheid. ${ }^{293}$

I08. Het verschil in benadering tussen beide landen mag niet verhullen dat de worsteling dezelfde is. Beide rechtssystemen betrachten hetzelfde evenwicht tussen het algemeen en het private belang. Enkel het uitgangspunt verschilt, hoewel ook dit geen vaststaand gegeven hoeft te zijn. Veeleer gaat het over een glijdende schaal, waarbij landen op een gegeven ogenblik als meer privaat- of meer publiekrechtelijk kunnen worden beschouwd. ${ }^{294}$

I09. Voorhouden dat privaat en publiek recht volledig inwisselbaar zijn, getuigt van weinig realiteitszin. Vooral de rechtsbescherming van derden is in een contractuele verhouding niet even sterk gewaarborgd als in een reglementaire verhouding. Evenmin mag de kloof tussen een privaat- en een publiekrechtelijke benadering worden uitvergroot. De voorgaande analyse illustreert dat het privaatrecht in het algemeen niet blind is voor de behoeften van het algemeen belang, waardoor de uitkomst vaak dezelfde kan zijn als na toepassing van het publiekrecht. Het is één van de vele verdiensten van professor Walter Van Gerven om hierop reeds enkele decennia geleden te hebben gewezen. ${ }^{295}$ Ook de voorstanders van de gemengde leer beklemtonen echter dat de autonomie van beide rechtsgebieden er niet aan in de weg mag staan dat 'men alleen dan tot uiteenlopende regelingen komt, indien daarvoor vanuit het te regelen onderwerp goede argumenten

29I Dit neemt niet weg dat er in de rechtsleer voor wordt gepleit om de beginselen van behoorlijk bestuur ook van toepassing te achten op het contractuele optreden van de overheid, behalve voor die taken die de wetgever zelf kwalificeert als louter private of commerciële activiteiten (F. VANDENDRIESSCHE, 'Het toepassingsgebied van de beginselen van behoorlijk bestuur' in I. OPDEBEEK en M.VANDAMME (eds.), Beginselenvanbehoorlijkbestuur, Brugge, dieKeure, 2006, 5I-57; zieookhierover: K. LEUS, 'Overeenkomsten met de overheid en overheidsovereenkomsten: bijzondere overeenkomsten en algemeen belang. De 'gemene', de 'gemengde' of de 'zuivere' rechtsleer?' in X. (eds.), Bijzondere overeenkomsten, XXXIVe Postuniversitaire cyclus W. Delva, 2007-2008, Mechelen, Kluwer, 434-435).

292 Het is in België overigens onbetwist dat een overheid ook in het kader van haar private handelen steeds de (publiekrechtelijke) grondrechten dient te respecteren (A. VAN OEVELEN, 'De contractuele versus de reglementaire rechtsverhouding tussen openbare nutsbedrijven en hun gebruikers, en de rechterlijke toetsing van de in die rechtsverhouding gehanteerde exoneratieclausules' (noot onder Cass. 4 december 2000), RW 2002-03, I579).

293 P. GOFFAUX, L'inexistence des privilèges de l'administration et le pouvoir d'exécution forcée, Brussel, Bruylant, 2002, I33, e.v.

294 S. LIERMAN, Besturen zonder grenzen. Over grijze zones en blinde vlekken, Acta Falconis VIII, Antwerpen, Intersentia, 20I5, 30.

295 Zie o.m. W. VAN GERVEN, 'Beginselen van behoorlijk handelen', RW I982, 962-978. 
bestaan'. ${ }^{296}$ De Raad van State lijkt hiervan eveneens overtuigd, waar hij overweegt dat '[het] gemis van de meest elementaire redelijkheid ook hierin kan bestaan dat in een materie die, was ze geen voorwerp van een openbare dienst, onder het contractenrecht zou vallen, zonder enige aanwijsbare reden regelingen worden vastgesteld die anders zijn dan die vervat in het contractenrecht'. ${ }^{297}$ In plaats van zich blind te staren op de tegenstelling tussen privaat- en publiekrecht, lijkt het inderdaad constructiever om uit te gaan van hun gelijkenissen en complementariteit. ${ }^{298}$ Naarmate de overheid het privaatrecht bewuster dan vandaag inzet met het oog op de behartiging van het algemeen belang, daalt de behoefte aan een publiekrechtelijke correctie. Publiek- en privaatrecht functioneren hierbij veeleer als communicerende vaten, de yin en yang van ons rechtssysteem.

296 M.W SCHELTEMA en M. SCHELTEMA, Gemeenschappelijk recht: wisselwerking tussen publiekrecht en privaatrecht, Deventer, Kluwer, 2003, 3. Ook P. Goffaux plaatste in zijn proefschrift een vergelijkbare caveat (P. GOFFAUX, L'inexistence des privilèges de l'administration et le pouvoir d'exécution forcée, Brussel, Bruylant, 2002, I84).

297 RvS 27 september I988, nr. 30.876, De Leener en Ballon.

298 W. VAN GERVEN en S. LIERMAN, Algemeen deel, veertig jaar later. Privaat- en publiekrecht in een meergelaagd kader van regelgeving, rechtsvorming en regeltoepassing, Mechelen, Kluwer, 2010, 524; S. LIERMAN, 'Law as a complex adaptive system: the importance of convergence in a multilayered legal order', MJ 2014, 6II-629. 